Gabriela Faria Oliveira

\title{
Metodologia otimizada para a determinação de digestibilidade de dietas para camarões marinhos em cultivo
}

\author{
Dissertação apresentada ao Instituto \\ Oceanográfico da Universidade de São Paulo, \\ como parte dos requisitos para obtenção do \\ título de Mestre em Ciências, área de \\ Oceanografia Biológica.
}

Orientador:

Prof. Dr. Daniel Eduardo Lavanholi de Lemos

São Paulo

2008 


\section{ÍNDICE}

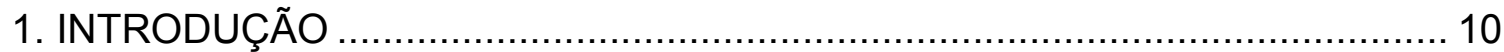

1. 1. A carcinicultura marinha nacional ................................................. 10

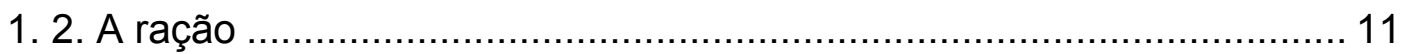

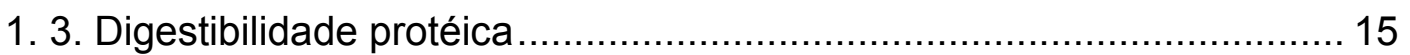

1. 4. Sistema fechado de recirculação de água marinha ........................... 18

1. 5. Dietas experimentais .......................................................... 19

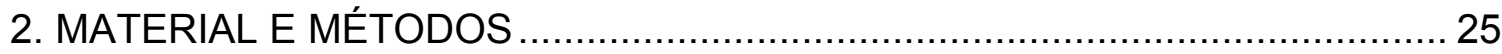

2.1. Sistema de recirculação de água marinha: desenho e operação .......... 25

2. 2. Maturação do sistema experimental ............................................ 29

2. 3. Cultivo dos organismos experimentais ........................................... 34

2. 4. Formulação e fabricação das dietas experimentais ............................. 38

2. 5. Teste de digestibilidade protéica ................................................... 45

2. 5. 1. Aclimatação às dietas experimentais .......................................................45

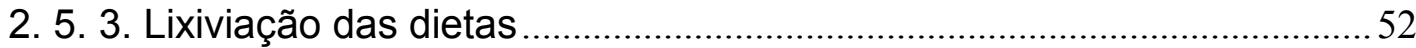

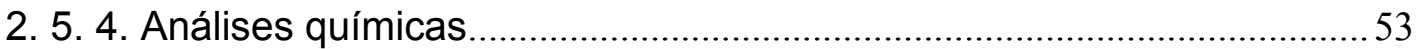

2. 6. Manutenção dos sistemas com camarões e qualidade da água ..........54

2. 7. Análises estatísticas .................................................................... 58

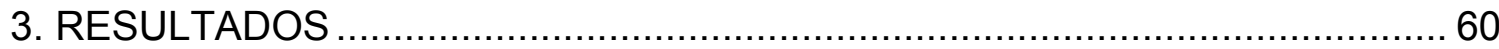

3. 1. Maturação do sistema experimental ................................................. 60

3. 2. Cultivo dos organismos experimentais ......................................... 63

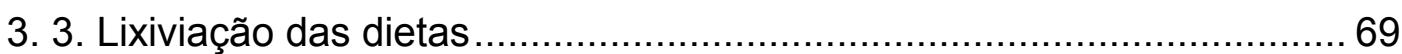

3. 4. Teste de digestibilidade protéica ............................................... 70

3. 6. Manutenção dos sistemas e qualidade da água ............................... 74

4. DISCUSSÃO

4. 1. Maturação do sistema experimental ................................................. 78

4. 2. Manutenção dos sistemas e qualidade da água ............................... 79

4. 3. Cultivo dos organismos experimentais ........................................... 82

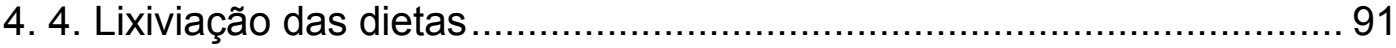

4. 5. Teste de digestibilidade protéica das dietas .................................... 93

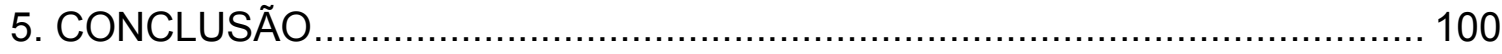




\section{ÍNDICE DE FIGURAS}

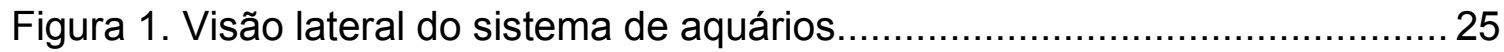

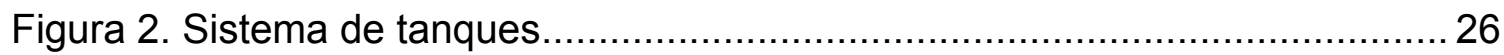

Figura 3. Aclimatação das pós-larvas de Litopenaeus vannamei........................ 35

Figura 4. Ingredientes utilizados na confecção das dietas-teste (da esquerda para direita, de cima para baixo): farinha de trigo, farelo de soja (FS), glúten de milho, farinha de peixe nacional, quirera de arroz, farinha de peixe peruana, farelo de soja texturizado (FST) e farelo de soja micronizado (FSM). 39

Figura 5. Tamanho dos pellets das dietas-teste: $1,55 \mathrm{~mm}$ de diâmetro e de 3 a 10 $\mathrm{mm}$ de comprimento.

Figura 6. Sistemas de aquários $(A)$, tanques $(B)$ e recipientes de alimentação $(C)$ marcados para cada dieta.

Figura 7. Cronograma da rotina em dia de teste de digestibilidade de dietas experimentais (FS, FST e FSM) para camarões Litopenaeus vannamei ....... 47

Figura 8. Sifonagem: processo utilizado na limpeza dos tanques e aquários. ......48

Figura 9. Coleta de fezes no sistema de aquários e posterior retirada do sal com água destilada durante o experimento de digestibilidade. 50

Figura 10. Coleta de fezes no sistema de tanques durante o experimento de digestibilidade. 51

Figura 11. Cronograma da rotina para camarões Litopenaeus vannamei em dias sem de teste de digestibilidade.

Figura 12. Kits comerciais para análise de amônia, nitrito e nitrato (da esquerda para direita). 57

Figura 13. Concentração de nitrogênio amoniacal total (N-AT) nos sistemas de recirculação $72 \mathrm{~h}$ após a primeira adição de cloreto de amônio $\left(\mathrm{NH}_{4} \mathrm{Cl}\right)$, durante o processo de maturação do filtro biológico. 
Figura 14. Concentração de nitrogênio amoniacal total (N-AT) nos sistemas de recirculação durante o processo de maturação do filtro biológico com cloreto de amônio $\left(\mathrm{NH}_{4} \mathrm{Cl}\right)$. A: sistema de aquários e $\mathrm{B}$ : sistema de tanques. 62

Figura 15. Concentração de nitrito $\left(\mathrm{N}-\mathrm{NO}_{2}\right)$ no sistema de aquários durante o processo de maturação do filtro biológico com cloreto de amônio $\left(\mathrm{NH}_{4} \mathrm{Cl}\right) \ldots .62$

Figura 16. Ração oferecida aos camarões em porcentagem de biomassa (peso médio ração $(\mathrm{g}) /$ peso médio individual camarão $(\mathrm{g}) \times 100)$ em relação à idade pós larval: sistemas de aquários $(A)$ e sistemas de tanques $(B)$. 67

Figura 17. Valores observados de nitrogênio amoniacal total (N-AT) e nitrito (N$\mathrm{NO}_{2}$ ) nos sistemas de recirculação, aquários $(\mathrm{A})$ e tanques $(\mathrm{B})$, durante todo o período com camarões: cultivo para crescimento (0 à 207 dias), aclimatação às dietas experimentais (210 à 235 dias) e teste de digestibilidade (236 à 272 dias). Resultados expressos como médias $(n=3)$.

Figura 18. Concentração de carbonato de cálcio $\left(\mathrm{CaCO}_{3}\right)$ durante a aclimatação às dietas experimentais (210 à 235 dias) e teste de digestibilidade (236 à 272 dias) nos sistemas de recirculação (aquários e tanques). Resultados expressos em $\mathrm{mg} / \mathrm{L}$ .77 


\section{ÍNDICE DE TABELAS}

Tabela 1. Excreção de amônia por pós-larvas de Litopenaeus vannamei e Farfantepenaeus paulensis (pu: peso úmido, ps: peso seco, J: Joule, N-AT: nitrogênio amoniacal total).

Tabela 2. Concentração letal com mortalidade de $50 \%$ dos indivíduos $\left(C L_{50}\right)$ para amônia, expressa como nitrogênio amoniacal total (N-AT), efeitos crônicos e níveis de segurança para $\mathrm{N}-\mathrm{AT}$, nitrito $\left(\mathrm{N}-\mathrm{NO}_{2}\right)$, nitrato $\left(\mathrm{N}^{-\mathrm{NO}_{3}}\right)$ e amônia não ionizada $\left(\mathrm{N}^{-\mathrm{NH}_{3}}\right)$ para diferentes estágios de Farfantepenaeus paulensis e Litopenaeus vannamei.

Tabela 3. Composição centesimal e energia dos ingredientes (matéria úmida) utilizados na fabricação das dietas experimentais. Resultados expressos como média (desvio padrão) ( $n=2$, exceto para Energia, onde $n=3$ ).

Tabela 4. Formulação das dietas-teste: farelo de soja (FS), farelo de soja texturizado (FST) e farelo de soja micronizado (FSM).

Tabela 5. Composição centesimal, energética e a relação proteína/energia (P:E) das dietas-teste (matéria úmida): farelo de soja (FS), farelo de soja texturizado (FST) e farelo de soja micronizado (FSM). Resultados expressos como média (desvio padrão) ( $n=2$, exceto para umidade, onde $n=5$ e óxido crômico, $n=3$ ).

Tabela 6. Temperatura ( $\mathrm{T}$ ), salinidade (S) e pH em ambos os sistemas durante o período de maturação. Valores expressos em média (desvio padrão). 60

Tabela 7. Peso úmido e taxa de crescimento individual de Litopenaeus vannamei em função do sistema de cultivo: aquários $(A)$ e tanques $(T)$, durante o cultivo com ração comercial. Resultados expressos como média (desvio padrão) [n].

Tabela 8. Densidades dos camarões Litopenaeus vannamei nos diferentes sistemas: aquários $(\mathrm{A})$ e tanques $(\mathrm{T})$ durante o cultivo com ração comercial. Resultados expressos como média (desvio padrão). .65 
Tabela 9. Taxa de sobrevivência de Litopenaeus vannamei em função do sistema de cultivo: aquários $(\mathrm{A})$ e tanques $(\mathrm{T})$ durante o período de cultivo com ração comercial*.

Tabela 10. Médias de peso úmido inicial (PL106), final (PL217), ganho de peso e taxa de crescimento de Litopenaeus vannamei após $3 \mathrm{~g}$, durante o período de alimentação com ração comercial nos sistemas de aquários e tanques. Resultados expressos como média (g), desvio padrão (DP) e coeficiente de variação (CV\%). 68

Tabela 11. Concentração média (\%) (matéria seca), desvio padrão e coeficiente de variação (\%) e lixiviação (\%) de proteína bruta (PB) e óxido crômico ( $\mathrm{Cr}$ ) nas dietas experimentais (FS, FST e FSM) após imersão em água salgada (n $=2$, exceto $\mathrm{Cr}$ Omin, onde $\mathrm{n}=3$ ).

Tabela 12. Digestibilidade aparente de proteína bruta (DAPB) (\%) para as dietas experimentais FS, FST e FSM, utilizando o método do marcador inerte (óxido crômico). Resultados expressos em média (desvio padrão) [n]. 71

Tabela 13. Peso úmido inicial (PL238), final (PL282), ganho de peso e taxa de crescimento de Litopenaeus vannamei durante o período de alimentação com dietas experimentais (FS, FST e FSM). Resultados expressos como peso médio em gramas $(\mathrm{g})$ [n aquários/tanques], desvio padrão (DP) e coeficiente de variação em porcentagem (CV\%). 73

Tabela 14. Temperatura (T), salinidade (S) e pH em ambos os sistemas durante o período de cultivo dos camarões, aclimatação às dietas e teste de digestibilidade. Valores expressos em média (desvio padrão). 74 
À Valentina, a mais bela flor, que me acompanhou durante o final dos trabalhos e chegou para alegrar todos os momentos desde então... 


\section{AGRADECIMENTOS}

Ao meu orientador, Prof. Dr. Daniel Lemos, pela confiança em mim depositada e condução durante o mestrado.

À família, minha mãe, sempre incentivadora da minha vida profissional e que me apoiou nos momentos mais críticos dessa jornada, e à minha irmã Cynthia, pela amizade, descontração, companhia e ajuda. Sem vocês este trabalho dificilmente seria concluído!

À COSEAS (Coordenadoria de Assistência Social), pela moradia.

À FAPESP (Fundação de Amparo à Pesquisa do Estado de São Paulo), pela bolsa concedida.

Aos colegas de laboratório, Raul e Rodrigo, pela grande ajuda durante a fase experimental.

Ao pessoal do Laboratório de Ecofisiologia, Prof. Dr. Phan Van Ngan, técnica Maria José e Thaís, pelo empréstimo de materiais e apoio técnico.

Aos técnicos do Instituto Oceanográfico: Marta, Tomás, Luís, Flávia, Lourival, Tie, Mayza, Ricardo e Walter por todo apoio durante minha pesquisa.

Às meninas da Secretaria de Pós, Ana Paula e Silvana, sempre fazendo o possível e o impossível! E da Secretaria do DOB, Marlene e Mirian.

Ao Sérgio e Sr. Mário, do Museu Oceanográfico, pelo auxílio sempre que necessário.

Ao pessoal do transporte, elétrica e oficina do Instituto Oceanográfico.

Às amigas:

Lana e Marta, pelas MUITAS conversas, amigas que fiz e jamais esquecerei.

Jah e Bê, sempre presentes e dispostas à ajudar.

Cruspianas: Elis, Luz, Jéssica, Verônica e Lilica, pela amizade e convívio.

Sandra, Jack, Cíntia e Keyi, por mais conversas, descontração e encontros laboratoriais em finais de semanas solitários. 


\section{RESUMO}

A aqüicultura desenvolveu-se rapidamente nos últimos anos, sendo a carcinicultura um dos segmentos mais lucrativos e crescentes, onde a ração representa o custo mais elevado da produção e a maior fonte de poluição das fazendas de camarão. Nesse contexto, verifica-se a busca por rações de qualidade e novos ingredientes. Assim, o presente trabalho objetivou aperfeiçoar o método in vivo de análise da digestibilidade de rações, desenvolvendo sistemas de cultivo (aquários: 14,3L e tanques: 160L), com recirculação de água marinha e filtro biológico, empregando rações comerciais (fase de crescimento) e dietas experimentais com diferentes produtos da soja (farelo de soja, farelo de soja texturlzado e farelo de soja micronizado) e marcador de óxido crômico (teste de digestibilidade) em camarões da espécie Litopenaeus vannamei. Os sistemas e a manutenção aplicada foram eficientes na conservação da estabilidade dos parâmetros abióticos monitorados (compostos nitrogenados, temperatura, salinidade e $\mathrm{pH})$. Os camarões apresentaram maior ganho de peso $(\mathrm{P}<0,05)$ com menores coeficientes de variação nos tanques. Não houve diferenças $(P>0,05)$ entre as dietas testadas (aquários), mas a digestibilidade acompanhou o maior processamento da soja (tanques). Os resultados sugerem a maior adequabilidade dos tanques para testes nutricionais.

Palavras-chave: sistemas de recirculação, digestibilidade, método in vivo, Litopenaeus vannamei, dieta experimental, soja, proteína, óxido crômico. 


\section{ABSTRACT}

Aquaculture have developed quickly in the last years, being the shrimp culture the more profitable and increasing sector. Feed comprise the highest variable costs of production and a major pollution source from shrimp farms. Hence is the search for quality feeds and new ingredients. Thus, the present work aimed to improve the in vivo method of feed protein digestibility, developing culture systems (aquariums: 14,3L and tanks: 160L) with seawater recirculation and biological filters. Commercial feeds (growth phase) and experimental diets with different soy products (soybean meal, texturized soybean meal and micronized soybean meal) with chromic oxide as marker (digestibility test) in Litopenaeus vannamei shrimps. Systems and maintenance procedures were efficient in the conservation of abiotic parameters (nitrogen products, temperature, salinity and $\mathrm{pH}$ ). Shrimps showed higher weight gain $(P<0,05)$ with low variation coefficient in the tanks compared to aquaria. No difference $(P>0,05)$ was observed between the diets tested in the aquaria. But the digestibility was major to higher processed soybean meal (tanks). The results suggest the better adequacy to nutritional tests.

Key-words: seawater recirculation system, digestibility, in vivo method, Litopenaeus vannamei, experimental diet, soy, protein, chromic oxide. 


\section{INTRODUÇÃO}

\section{1. A carcinicultura marinha nacional}

Atualmente, a pesca extrativa mundial encontra-se aparentemente no máximo de seu potencial e, em contraste, a produção da aqüicultura continua crescente, tanto em termos quantitativos como em relação à sua contribuição ao suprimento de pescado para consumo humano direto (FAO, 2007). Um dos fatores que influenciam este crescimento é a depleção de vários estoques pesqueiros, que induz à expansão da produção de pescados por meio da aqüicultura (GOLDBURG \& NAYLOR, 2005).

A produção de alimento de origem animal pela aqüicultura tem crescido mais rapidamente que outros setores produtores de alimento (MUIR, 2005; FAO, 2007). Mundialmente, a taxa média de crescimento do setor aqüícola desde 1970 é de $8,8 \%$ ao ano, enquanto a pesca extrativa apresentou um crescimento de $1,2 \%$ e os sistemas terrestres de produção de carne cresceram 2,8\% (FAO, 2007). O cultivo de camarões é um dos segmentos da indústria de aqüicultura mais lucrativos e apresenta também crescimento acelerado (TACON, 2002; FAO, 2007), apesar da recente problemática com relação à saúde dos animais ocorrida em vários países (FAO, 2006).

Nesse contexto, a carcinicultura marinha brasileira apresenta, atualmente, números representativos, com uma produção total de 65.000 toneladas em 2006 e a segunda maior produtividade mundial em 2005 (4.333 kg/ha/ano) (ABCC, 2008a, 2008b). O acelerado ritmo de crescimento da atividade foi observado a partir da década de 90, com a introdução da espécie exótica Litopenaeus vannamei (sinônimo: Penaeus vannamei), popularmente conhecida como camarão-branco- 
do-Pacífico (BORGHETTI et al., 2003; ABCC, 2004). O desenvolvimento do cultivo desta espécie deu-se em função do domínio da técnica de criação, desenvolvida com sucesso em outros países da América Latina, da disponibilidade de alimento (ração) nutricionalmente adequado e da elevada capacidade de adaptação da espécie às condições de cultivo semi-intensivo e intensivo, superior à outras espécies já cultivadas no país, como as espécies autóctones Farfantepenaeus subtilis, F. paulensis e L. schimitti, e também à alóctone, Marsupenaeus japonicus (LEMOS et al., 2000; BORGHETTI et al., 2003; ABCC, 2004). No Brasil, a espécie de camarão marinho $L$. vannamei é basicamente a única espécie cultivada comercialmente (ROCHA \& CARVALHO, 2006).

\section{2. A ração}

Atualmente, a carcinicultura tem evoluído com relação à intensificação dos sistemas e das técnicas de produção. No entanto, esse processo pode implicar em custos ambientais, ao utilizar mais intensivamente os recursos naturais e possivelmente gerando um aporte maior de efluentes aos ecossistemas adjacentes às fazendas de camarão (BORGHETTI et al., 2003). Neste sentido, a carcinicultura pode ser mais poluente que a piscicultura, devido à maior dificuldade em equiparar a quantidade de ração fornecida com a demanda (JORY et al., 2001). Nos cultivos extensivos de camarão o alimento é basicamente natural (TACON, 2002), como detritos vegetais e invertebrados (SOARES, 2004), com pouca ou nenhuma fertilização (adição de fertilizantes químicos ou matéria orgânica), nos semi-intesivos há fertilização e/ou oferta suplementar/completa de 
alimento (ração), enquanto nos intensivos pratica-se a fertilização e/ou a oferta completa de alimento (TACON, 2002).

Uma das maiores fontes de poluentes em sistemas de cultivos é a ração, principalmente com relação ao seu desempenho. Isto é, a quantidade de resíduo produzido por um sistema de cultivo, por meio do excesso de alimentação, da instabilidade da ração e da possível baixa absorção dos nutrientes, contribui para elevar a concentração de fósforo, compostos nitrogenados e matéria orgânica particulada e dissolvida, que são os principais elementos poluentes provenientes da ração (BURFORD et al., 2001; MUKHI et al., 2001). Estes compostos podem ocorrer em quantidades excessivas em cultivos intensivos (LAWRENCE et al., 2001). No Brasil, 15\% das fazendas de camarão utilizam sistemas intensivos de produção e $85 \%$ sistemas semi-intensivos (NUNES \& SURESH, 2001) em processo de intensificação (BORGHETTI et al., 2003).

Segundo a FAO (2004), o desenvolvimento de estratégias para a substituição dos sistemas de cultivos atuais para práticas mais sustentáveis é um objetivo-chave. O desenvolvimento pleno da atividade depende, principalmente, dos setores de apoio à produção, como fábricas de ração, empresas de consultoria técnica, e laboratórios de pós-larvas e diagnóstico de patologias (BORGHETTI et al., 2003), além de pesquisas científicas que busquem soluções sustentáveis (ambientalmente, economicamente e socialmente) para suporte à políticas públicas de administração do setor (FAO, 2007).

Além do potencial poluidor, a ração representa o maior custo operacional no cultivo de camarões, alcançando mais de $50 \%$ do custo total da produção (AKIYAMA et al., 1992; SHIAU, 1998; HERTRAMPF \& PIEDAD-PASCUAL, 2000). 
No entanto, nem sempre uma ração nutricionalmente balanceada irá produzir o crescimento esperado, devido à ausência de biodisponibilidade desses nutrientes (LEE \& LAWRENCE, 1997). Portanto, o investimento empregado pode não apresentar os resultados esperados na produção e a ração fornecida será transformada nos compostos anteriormente citados. Segundo Mukhi et al. (2001), 30 a $40 \%$ do nitrogênio presente nos efluentes pode ser proveniente de ração não ingerida. Desta forma, evidencia-se que a qualidade da ração é fator essencial para cultivos intensivos e semi-intensivos, onde a fonte principal de alimento é a ração ao invés de alimento natural (SHIAU, 1998).

A formulação de uma ração é baseada nos requerimentos nutricionais dos organismos cultivados. Para camarões, a proteína é o maior e mais caro componente da ração (AKIYAMA et al., 1992; SHIAU, 1998; LEMOS, 2003), pois é o principal nutriente limitante do crescimento, sendo indispensável funcional e estruturalmente a todos os organismos vivos, não apenas à camarões (SHIAU, 1998; KURESHY \& DAVIS, 2002). Embora estes organismos sejam considerados onívoros ou detritívoros na natureza (BAILEY-BROCK \& MOSS, 1992), podendo uma espécie apresentar hábitos mais carnívoros do que outra (TACON, 2002), estudos de conteúdo estomacal em peneídeos demonstraram a maior ocorrência de alimento de origem animal (NUNES et al., 1997; SOARES, 2004), evidenciando a importância da proteína na composição da ração.

Além disso, no Brasil, a maioria dos sistemas produtivos de camarão localizam-se em ambientes estuarinos (baixa salinidade) e, de acordo com Lei et al. (1989 apud SHIAU, 1998), camarões cultivados em locais de baixa salinidade tendem a utilizar mais as proteínas como fonte de energia, ao invés de lipídeos. A 
proteína não utilizada para crescimento e obtenção de energia pode gerar maior liberação de nitrogênio metabólico (excreção) no meio de cultivo ( $\mathrm{CHO}$ et al., 1994).

Em rações para camarão, o ingrediente protéico tradicionalmente mais utilizado é a farinha de peixe, que vinha respondendo por $25 \%$ a $50 \%$ do total da formulação (TACON \& AKIYAMA, 1997) e ainda é considerado o maior constituinte em rações para espécies onívoras/detritívoras, como os camarões marinhos (TACON, 2006; FAO, 2007). A utilização de farinha de peixe na ração deve-se ao aporte de proteínas de alta qualidade e balanço de aminoácidos e ácidos graxos adequado para o rápido crescimento dos organismos marinhos, principalmente os carnívoros (CRUZ-SUÁREZ et al., 2000; HERTRAMPF \& PIEDAD-PASCUAL, 2000).

Tal situação demonstra porque a disponibilidade de proteína para a produção de ração ainda é dependente da pesca extrativa e porque, ao contrário do que se acredita, a aqüicultura tem contribuído para o aumento da pressão de pesca, criando, desta forma, um paradoxo: a aqüicultura pode tanto ser uma solução como um agravante para o colapso dos estoques pesqueiros mundiais (NAYLOR et al., 2000).

A utilização da farinha de pescado como ingrediente de rações é afetada por fatores econômicos (e.g., preço), ecológicos (e.g., sobrepesca, eventos El Niño) e de mercado (e.g., disponibilidade), que elevam seu custo e restringem a sua utilização (GUZMAN, 1996). Como alternativa tem-se utilizado subprodutos da pesca e pecuária, além de ingredientes de origem vegetal, embora estes últimos possam apresentar maior quantidade de fatores antinutricionais e deficiência de 
aminoácidos essenciais (LONGAS, 1996). Recentemente, a substituição por fontes protéicas alternativas tem sido cada vez mais utilizada em formulações de rações comerciais (EAPA, 2006; SWICK, 2007).

Desta forma, a busca por novos ingredientes, assim como a avaliação da qualidade das rações comerciais utilizadas atualmente, tem sido objetivo de diversas pesquisas atuais (COUSIN et al., 1996; LEMOS et al., 2004; AMAYA et al., 2007). No entanto, o controle de qualidade de rações ainda é realizado prioritariamente por análises composicionais, embora o valor nutritivo de um alimento, como dito anteriormente, depende, principalmente, da biodisponibilidade de seus nutrientes e não apenas de sua composição (CRUZ-SUÁREZ et al., 2000).

Assim, dados de digestibilidade podem interessar à aqüicultores e produtores de ração, pois são importantes para a formulação de rações menos poluentes (LAWRENCE \& LEE, 1997) e mais eficientes nutricionalmente, capazes de gerar benefícios econômicos e ambientais.

\section{3. Digestibilidade protéica}

Para medir a disponibilidade de um nutriente o método empírico mais utilizado é a digestibilidade aparente (DA), que descreve o quanto dos nutrientes provenientes da dieta é absorvido (LEE \& LAWRENCE, 1997) e direcionado para crescimento e metabolismo (LEMOS, 2003). O termo aparente deve-se à possível presença nas fezes de outros componentes, como células da mucosa estomacal, bactérias e enzimas digestivas, além daqueles derivados do alimento (LEE \& LAWRENCE, 1997; CÓRDOVA-MURUETA et al., 2003), pois a distinção entre o 
que é somente proveniente do alimento (digestibilidade verdadeira) é muito difícil de se determinar (MAYNARD et al., 1979 apud LEE \& LAWRENCE, 1997)

Existem diversos métodos para a avaliação da DA, tanto com o cultivo de animais (métodos in vivo) (SMITH \& TABRETT, 2004) quanto por meio da análise de reações bioquímicas (in vitro) (LEMOS, 2003). Atualmente, o método in vivo mais utilizado emprega o marcador inerte de óxido crômico $\left(\mathrm{Cr}_{2} \mathrm{O}_{3}\right)$ incluído em dietas experimentais, seguindo-se a coleta e análise de sua concentração e do nutriente avaliado (e.g., proteína bruta, lipídeos, etc) na dieta ingerida e nas fezes, calculando-se a DA pela proporção entre os compostos antes (dieta) e após a ingestão (fezes). Outro método in vivo bastante recomendado é o método gravimétrico ou coleta total, que consiste na quantificação de nutrientes ingeridos e excretados, através da coleta total de ração não ingerida e fezes dos organismos cultivados, no entanto, ambos os métodos apresentam pontos negativos e positivos (LEE \& LAWRENCE, 1997).

Lee \& Lawrence (1997) consideram o método gravimétrico teoricamente o mais preciso para avaliação da DA de ração, no entanto, os autores citam como fontes de erro neste método a lixiviação da dieta, que dificulta a total recuperação e a correta quantificação do alimento não ingerido, além da possibilidade de mistura entre fezes e ração. Smith \& Tabrett (2004) citam que na avaliação de dietas experimentais, as quais apresentam menor estabilidade na água do que rações comerciais, a utilização de marcadores pode produzir resultados melhores aos encontrados pelo método gravimétrico, uma vez que não é necessário a coleta total da ração não ingerida. No entanto, a lixiviação de nutrientes da dieta ingerida é uma fonte de erro em ambos os métodos (LEE \& LAWRENCE, 1997), 
bem como a incompleta coleta de fezes no gravimétrico ou insuficiente no método do marcador (SMITH \& TABRETT, 2004).

Com relação aos erros no método do marcador, o mais citado é a passagem diferencial do óxido crômico pelo sistema digestivo de alguns animais aquáticos (TACON \& RODRIGUES, 1984; LEAVITT, 1985; SHIPTON \& BRITZ, 2001), mas este fato ainda não é um consenso. Lee \& Lawrence (1997) citam trabalhos com camarões marinhos e dulcícolas onde a passagem do marcador é homogênea. Para reduzir esta fonte de erro Smith \& Tabrett (2004) recomendam a completa recuperação das fezes, como no método gravimétrico.

A utilização do método indireto (marcador inerte) depende de pressupostos com relação ao marcador empregado: o marcado deve ser inerte, não interferindo na taxa de passagem pelo trato digestivo do nutriente avaliado, na sua digestão, absorção e em nem uma outra função fisiológica; a taxa de passagem entre o marcador e o nutriente avaliado deve ser igual e; a razão entre nutriente e marcador na porção ingerida deve ser a mesma da ração (SUGIURA, 2000; SMITH \& TABRETT, 2004).

Adicionalmente, Sugiura (2000) recomenda que o marcador deve ser inerte também em relação à dieta e seus componentes, não apresentando nenhuma interação, reação ou efeito catalítico. Nesse sentido, Divakaran et al. (2000) verificaram a interação entre o marcador e farelo de soja em concentrações de $1 \%$ de óxido crômico na dieta e sugeriram a busca de outros compostos inertes para pesquisa de digestibilidade em camarão. No entanto, Sugiura (2000) relata que a comparação da DA obtida com o método direto (gravimétrico) e o indireto 
(com marcador inerte óxido crômico) em peixes tem apresentado valores similares, como observado por Smith \& Tabrett (2004) em camarões.

Assim, considerando que o método gravimétrico é custoso, demandando tempo e mão de obra (DIMES et al., 1994; SMITH \& TABRETT, 2004) e o método com marcador é mais rápido, experimentalmente mais simples e apresenta mais dados na literatura para comparação (LEE \& LAWRENCE, 1997), escolheu-se o marcador de óxido crômico para o teste de digestibilidade.

Outra fonte causadora de erros em experimentos de digestibilidade é a manipulação dos animais, que afeta o comportamento alimentar dos camarões, assim como outros fatores estressores do trato digestivo de camarões (MUHLIAALMAZÁN \& GARCIA-CARREÑO, 2002; CÓRDOVA-MURUETA et. al., 2004). Nesse sentido, o desenvolvimento de um sistema de cultivo com recirculação de água marinha é capaz de viabilizar a manutenção dos organismos em laboratório de maneira a reduzir a manipulação (KAMIMURA, 2002).

\section{4. Sistema fechado de recirculação de água marinha}

Em sistemas fechados, assim como em ambiente natural de cultivo, os principais contaminantes da água são os compostos nitrogenados provenientes da oxidação de matéria orgânica (e.g., ração e fezes) e de amônia, principal produto excretado por crustáceos (HUGUENIN \& COLT, 1989). Na maioria dos animais aquáticos a amônia é o principal produto final do metabolismo de proteínas, sendo tóxica na sua forma livre ou não ionizada (gás dissolvido na água, $\mathrm{NH}_{3}$ ), enquanto a forma ionizada (íon amônio solúvel na água, $\mathrm{NH}_{4}{ }^{+}$), possui baixa toxicidade. 
Durante o processo de oxidação da amônia, ou nitrificação, o nitrito $\left(\mathrm{NO}_{2}\right)$ é um intermediário na conversão de amônia para nitrato $\left(\mathrm{NO}_{3}\right)$ e a toxicidade deste composto $\left(\mathrm{NO}_{2}\right)$ deriva de sua capacidade de oxidar o ferro na hemoglobina, tornando-o incapaz de transportar o oxigênio $\left(\mathrm{O}_{2}\right)$. O composto final produzido pela oxidação da amônia, o $\mathrm{NO}_{3}$, geralmente, é menos tóxico, exceto em concentrações muito elevadas, as quais podem ocorrer em sistemas fechados (HUGUENIN \& COLT, 1989).

A remoção dos compostos citados acima pode ser obtida através de filtro biológico, utilizados com êxito na larvicultura e na produção e manutenção de cultivos de camarões (DANIELS et al., 1992; DAVIS \& ARNOLD, 1998). Além disto, um sistema fechado é a forma mais segura para a realização de experimentos com a espécie objeto deste trabalho, L. vannamei, um animal alóctone. Desta forma, o presente trabalho desenvolveu um sistema fechado de recirculação de água marinha, com a utilização de filtros biológicos, que permitiu determinações de crescimento e eficiência da absorção de proteína (digestibilidade aparente de proteína bruta - DAPB).

\section{5. Dietas experimentais}

A busca por novos ingredientes é um aspecto importante na substituição das fontes protéicas marinhas atualmente utilizadas, como a farinha e o óleo de peixe (TACON, 2002; WATANABE, 2002). Assim, na avaliação dos sistemas de recirculação de água marinha para teste de DAPB com L. vannamei foram utilizadas dietas experimentais. Estas dietas consistiam de ingredientes 
comumente utilizados em aqüicultura, inclusive farinha de peixe (em quantidades reduzidas), acrescida de diferentes tipos de soja.

Atualmente, a soja é utilizada entre $20 \%$ a $25 \%$ nas rações comerciais (SWICK, 2007), principalmente na forma de farelo de soja (soybean meal) (HERTRAMPF \& PIEDAD-PASCUAL, 2000), no entanto, sua utilização ainda é limitada em camarões marinhos devido ao seu baixo conteúdo protéico comparado às farinhas de peixe, deficiência de alguns aminoácidos, fatores antinutricionais, entre outras características. Assim, a busca por rações de conteúdo protéico apenas de origem vegetal tem crescido, abrindo espaço para novos ingredientes e processamentos diferenciados (SWICK, 2007). A seguir, é feita a descrição de cada ingrediente utilizado nas dietas experimentais do presente trabalho, segundo Hertrampf \& Piedad-Pascual (2000):

FARINHA DE TRIGO: a obtenção da farinha é feita por meio da moagem do grão do trigo, que consiste de várias etapas, como a limpeza para separação de impurezas (terra, pedras, areia, etc); o acondicionamento, que objetiva a facilitação da separação do endosperma (farinha) do farelo durante a moagem; a trituração e; a separação, de acordo com o tamanho das partículas, nos principais produtos do trigo - farinha, farelo e germe. A composição química do trigo é afetada dor diversos fatores, tais como, tipo de solo, clima e estação do ano no qual o trigo é cultivado, a variedade do trigo, o processo de moagem e o uso de fertilizantes também afetam a composição. Em rações para camarão, além do valor energético, a farinha de trigo é utilizada como aglutinante, em níveis de $20 \%$ a $30 \%$, como também na confecção das dietas experimentais deste trabalho $(22 \%)$. 
GLÚTEN DE MILHO: é a porção protéica da semente de milho e um produto da moagem úmida no processamento do amido. Existem dois tipos de glúten de milho, um contém casca, água e germe e, o outro, o glúten seco, é praticamente livre de outros componentes. Outra diferença esta no conteúdo protéico, que é alto para o glúten seco, em torno de $60 \%$, como também pode ser verificado no glúten utilizado neste trabalho $(67 \%)$ e em torno de $25 \%$ no glúten úmido. Como em outros grãos, a composição química da semente do milho e seus derivados é variável em função de fatores citados anteriormente.

QUIRERA DE ARROZ: Após limpeza e remoção da palha e da casca do arroz, o farelo do arroz também é separado produzindo o grão polido. Além do farelo, resulta deste processo, a quirera de arroz. É utilizado como fonte energética e aglutinante (quando cozido) em rações. Para camarões, a quirera de arroz geralmente é incorporada em baixos níveis.

FARINHA DE PEIXE: a maioria das farinhas comerciais de peixe é produzida a partir de várias espécies de peixes e pode ser rotulada em função da cor (branca ou marrom), espécie de pescado, procedimento de manufatura ou país de origem, como podemos observar nas farinhas utilizadas no presente trabalho (nacional e peruana). A qualidade destas farinhas depende de vários fatores, tais como, temperatura no momento da captura do pescado, método de captura, temperatura e tempo de estocagem antes do processamento, e composição do pescado capturado. O princípio do processamento da farinha de peixe é a separação da parte sólida, da água e óleos. Para tal, existem dois procedimentos principais: a secagem direta e a secagem com cozimento prévio, resultando este último, em uma farinha de melhor qualidade, uma vez que danifica 
menos os nutrientes por utilizar baixas temperaturas. Com relação às farinhas de peixe neste trabalho, a peruana geralmente é produzida à partir de pescados inteiros, enquanto a nacional é proveniente de resíduos do processamento industrial de peixes (OLIVEIRA, 2002).

Com relação aos produtos oriundos da soja, estes são produzidos a partir da extração do óleo de soja por pressão e solventes químicos, após limpeza, descasque e moagem da semente. Os resíduos da extração do óleo de soja eram, no passado, subprodutos, mas atualmente, em função da crescente demanda por proteína para produção animal (terrestre e aquática), estes produtos são considerados até mais importantes que o óleo, não só por seu elevado conteúdo protéico, mas também devido a sua ampla disponibilidade mundial (HERTRAMPF \& PIEDAD-PASCUAL, 2000). No caso da aqüicultura, a importância da soja como ingrediente para ração é também função do elevado custo da proteína oriunda de pescado e do potencial do pescado como transmissor de doenças (SWICK, 2007).

Segundo Hertrampf \& Piedad-Pascual (2000), os níveis de gordura residual são indicadores do processo utilizado na extração da gordura. Neste trabalho, os valores de gordura apresentados pelos produtos de soja utilizados nas dietas experimentais (abaixo de $5 \%$ ) sugere que foram obtidos após extração química. A seguir, a descrição dos ingredientes de soja utilizados na fabricação das dietas experimentais:

FARELO DE SOJA (FS): para produção do farelo as sementes de soja são limpas, passam por um leve aquecimento que auxilia na retirada das cascas, em seguidas são quebradas e as cascas retiradas por aspiração. Os pedaços das sementes são então acondicionados no vapor e em seguida cortados em flocos 
para a extração química do óleo, geralmente com hexano. O solvente é retirado por evaporação, através da aplicação de calor. Esta tostagem é feita até um determinado conteúdo de umidade, valor de teste de urease e coloração, resultando na remoção do hexano e na desnaturação de fatores antinutricionais. Em seguida os grãos são triturados em partículas de tamanho uniforme (HERTRAMPF \& PIEDAD-PASCUAL, 2000; SWICK, 2007). O FS utilizado neste trabalho, a julgar por seu conteúdo de lipídeos e fibra, continha casca, que segundo Bellaver \& Snizek Jr. (1999) é reincorporada ao farelo após moagem e tostagem da mesma, sendo que a adição da casca ao farelo é geralmente utilizada para ajustar o teor protéico do produto final.

FARELO DE SOJA TEXTURIZADO (FST): também conhecido como proteína texturizada de soja (PTS), é produzido à partir do farelo de soja sem casca, no qual é aplicado o processo de extrusão (CBRA, 2005), que consiste em cozimento $\left(>102^{\circ} \mathrm{C}\right)$ utilizando umidade, pressão e temperatura elevada por um curto período de tempo (CHAMBERLAIN, 2004). Segundo Cheftel (1986 apud BELLAVER \& SNIZEK JR., 1999), as principais funções deste processo são hidratação, mistura, tratamento térmico, gelatinização do amido, desnaturação das proteínas, destruição dos microorganismos e de alguns componentes tóxicos. O processo adicional de extrusão pode elevar a concentração de proteína, como verificado no presente trabalho $(54,1 \%)$ e próximo ao citado por MANDARINO \& RUFINO (2002) para PTS (50\% a 52\%), além de diminuir, ainda mais, os fatores antinutricionais.

FARELO DE SOJA MICRONIZADO (FSM): ingrediente não descrito nos manuais específicos de alimentação animal (HERTRAMPF \& PIEDAD-PASCUAL, 
2000; CBRA, 2005) e os detalhes de sua fabricação em escala industrial são incertos na literatura, no entanto, considerando seu conteúdo de proteína bruta $(48,7 \%)$, extrato etéreo $(1,63 \%)$ e fibra bruta $(3,42 \%)$, deve tratar-se também de farelo de soja descascada, com extração química dos lipídeos e aplicação do processo de micronização. Segundo Bellaver \& Snizek Jr. (1999) e Mendes et al. (2004), a micronização é geralmente aplicada na soja integral e consiste na exposição do grão à radiação infravermelha, a qual aquece a semente (150 à $180^{\circ} \mathrm{C}$ ) durante pouco tempo (2 à $5 \mathrm{~min}$.), agitando as moléculas e vaporizando a água, e como conseqüência, o grão incha e apresenta fissuras internas. 


\section{MATERIAL E MÉTODOS}

\subsection{Sistema de recirculação de água marinha: desenho e operação}

Foram construídos dois sistemas de recirculação de água marinha, um sistema de aquários (Figura 1), nos quais o teste de digestibilidade dos camarões foi feito individualmente, e um sistema de tanques (Figura 2), onde os camarões permaneceram em grupo durante o teste. Segundo Kamimura (2002), sistemas de recirculação de água marinha, similares aos descritos a seguir, mostraram-se viáveis tecnicamente, sob condições laboratoriais.

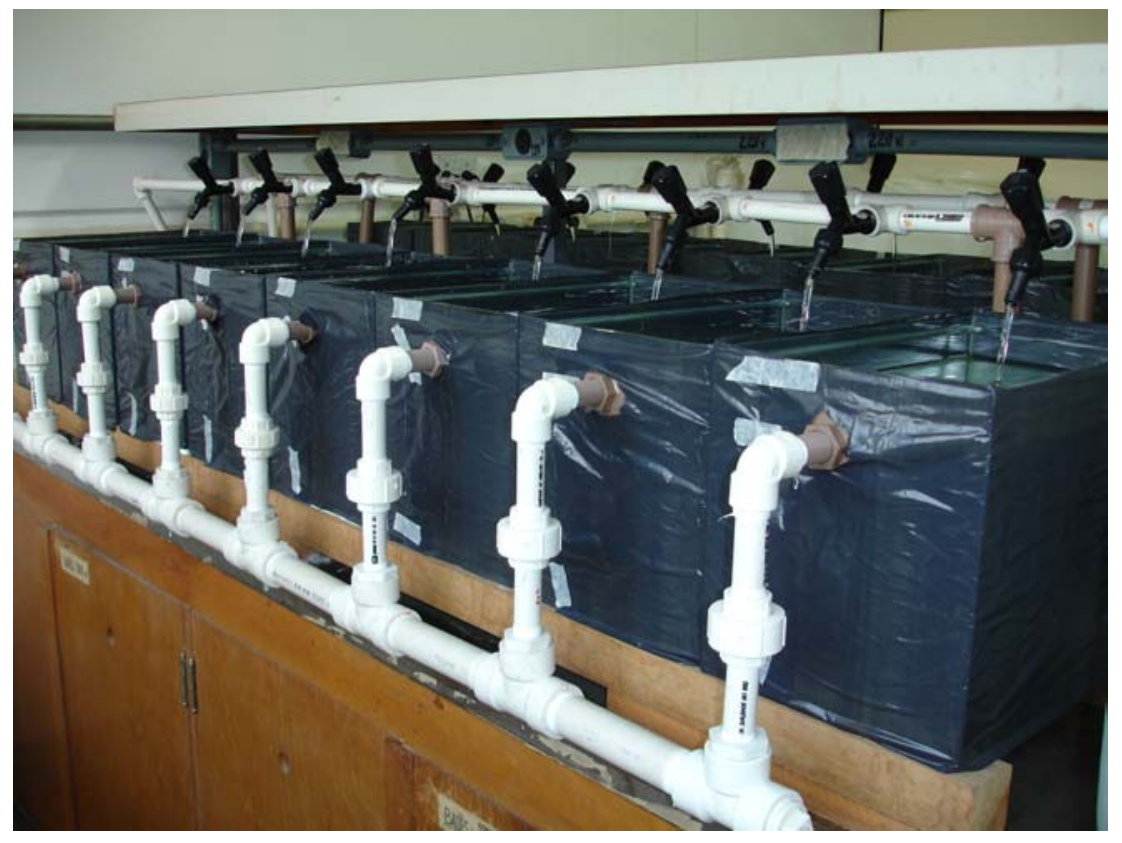

Figura 1. Visão lateral do sistema de aquários.

O sistema de aquários consistiu em 16 tanques retangulares de vidro transparente (dimensões: $23,5 \times 34,5 \times 21,5 \mathrm{~cm}$ cada) sobre uma bancada e um filtro biológico, também retangular e de vidro transparente $(50,0 \times 30,0 \times 80,0 \mathrm{~cm})$, 
sob a bancada dos aquários. O formato retangular apresenta menor custo comparado ao cilíndrico-cônico (SANDIFER et al., 1974 apud KAMIMURA, 2002).

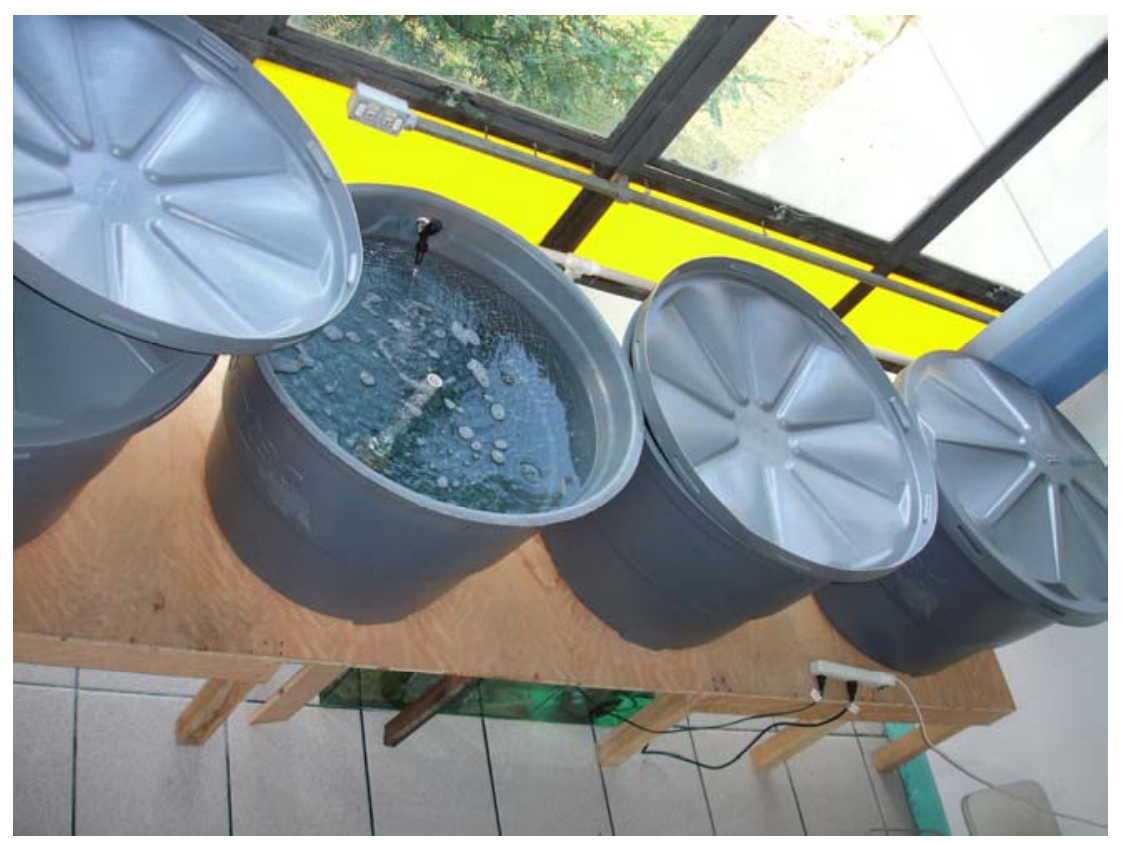

Figura 2. Sistema de tanques

Os aquários foram conectados ao filtro biológico por tubos e conexões de PVC, através dos quais a água escoava por gravidade (saída lateral próxima à superfície da água) até o filtro e retornava para os aquários por meio de uma bomba de sucção submersível (Modelo VA-2600, Via Aqua, Commodity Axis, EUA), e torneiras acima dos aquários, as quais permitiram o controle do fluxo de água para cada unidade experimental (aquário) e proporcionavam aeração por gravidade.

No filtro biológico, a água era aquecida por um aquecedor termostatizado (Modelo B-52, Yinsheng, China), aerada por gravidade, passava através de uma bolsa contendo grãos de carvão ativado envolta em manta de lã de vidro, onde sofria filtração física e química (adsorção pelo carvão ativado), e alcançava o 
substrato formado por rochas calcáreas, em sua maioria, e anéis de porcelana. $O$ substrato calcáreo tinha por finalidade manter o pH da água por meio da liberação de íons hidroxila $\left(\mathrm{OH}^{-}\right)$, através da lixiviação das rochas, além de aumentar a área de superfície para fixação das bactérias nitrificantes, as quais retiram os compostos nitrogenados da água (transformação biológica), área que era ampliada pela presença dos anéis de porcelana.

Os 16 aquários de vidro foram recobertos por plástico preto, a fim de manter a luminosidade o mais semelhante possível da existente no hábitat dos camarões, tanto em ambiente natural, como em cultivo comercial, além de evitar interações intraespecíficas durante o experimento de digestibilidade.

Após a chegada das pós-larvas de L. vannamei, os aquários foram tampados com uma tela de metal recoberta com o plástico preto, nesta tela foi feito um recorte, para entrada da água, recoberto com tela de nylon, para evitar o escape dos animais, comportamento típico da espécie (WYBAN, 1995). A tela de nylon também foi utilizada nas saídas de água, tanto nos aquários como nos tanques.

O sistema de tanques era composto por 4 tanques circulares de polietileno de 200L cada, suspensos por uma bancada de madeira, e filtro biológico $(46,5 \mathrm{x}$ $89,0 \times 46,0 \mathrm{~cm})$ sob a bancada. Similarmente ao sistema de aquários, as tubulações para distribuição de água eram compostas de canos de PVC, por onde a água escoava para o filtro biológico por gravidade e retornava aos tanques por meio de bomba de sucção submersível (Modelo VA-845A, Via Aqua, Commodity Axis, USA) e torneiras em cada tanque. Os sistemas diferiam apenas na 
localização do ponto de saída da água, que neste sistema encontrava-se no centro da unidade experimental (tanque).

Quanto ao filtro biológico, os componentes e o funcionamento deste eram totalmente análogos aos do sistema de aquários, com exceção de suas dimensões e área útil (descrita a seguir), que eram maiores devido a maior quantidade de água existente neste sistema.

Antes da introdução do substrato e da água salgada, foi feita a limpeza dos sistemas com esponja e água destilada. No sistema de aquários (vidros) foi utilizado também hipoclorito de sódio comercial $(\mathrm{NaClO})$ em água, como recomendado por Daniels et al. (1992). No sistema de tanques não foi utilizado cloro devido à composição dos tanques (polietileno), a qual dificulta a remoção do mesmo. A água com cloro foi mantida em recirculação durante 2 dias, em seguida foi retirada e substituída por água doce limpa, que foi mantida por mais 2 dias e novamente trocada por água doce, esta água foi trocada mais 2 vezes para total evaporação do cloro residual.

Após a limpeza, os sistemas foram preenchidos com água marinha natural e substrato, a água era previamente filtrada através de filtro tipo Cuno (porosidade $1 \mu \mathrm{m})$, proveniente da Base Norte do Instituto Oceanográfico (Ubatuba/SP). O volume útil de água foi estimado para cada sistema, sendo que o sistema de aquários apresentou um volume de 14,3 L para cada aquário (total de 229L) e, aproximadamente $55 \mathrm{~L}$ no filtro biológico, totalizando todo o sistema $284 \mathrm{~L}$. No sistema de tanques o volume útil era de aproximadamente $160 \mathrm{~L}$ em cada tanque (total de $640 \mathrm{~L}$ ) e cerca de $85 \mathrm{~L}$ no filtro biológico, que totalizavam $725 \mathrm{~L}$ em todo o sistema. 
A taxa de recirculação de água, a partir do fluxo apresentado pelos sistemas, também foi estimada. No sistema de tanques o fluxo foi de 6L/min/tanque, o que nos permitiu estimar a taxa de recirculação em 54 vezes/dia/tanque. Enquanto no sistema de aquários o fluxo de água foi de 3,4L/min/aquário e a taxa de recirculação estimada em 340 vezes/dia/aquário.

\section{2. Maturação do sistema experimental}

O processo de maturação ou "ativação" do filtro biológico consiste em promover o crescimento de bactérias nitrificantes no substrato, em quantidade suficiente para nitrificar $100 \%$ do máximo esperado de amônia produzida pelos organismos cultivados em 24 horas (DANIELS et al., 1992). A produção máxima de amônia excretada por pós-larvas de L. vannamei foi estimada por meio de bibliografia específica (LEMOS \& PHAN, 2001; BRITO et al., 2004; GÓMEZJIMENEZ et al., 2004) (Tabela 1).

Neste trabalho, a amônia estimada como excreção, utilizada para maturação e analisada nos sistemas foi reportada como nitrogênio amoniacal total (N-AT), que é a soma da amônia não ionizada e do íon amônio $\left(\mathrm{N}-\mathrm{AT}=\mathrm{NH}_{3}+\right.$ $\mathrm{NH}_{4}{ }^{+}$). Os compostos nitrito e nitrato também foram considerados à partir do nitrogênio, $\mathrm{N}-\mathrm{NO}_{2}$ e $\mathrm{N}-\mathrm{NO}_{3}$, respectivamente. 
Tabela 1. Excreção de amônia por pós-larvas de Litopenaeus vannamei e Farfantepenaeus paulensis (pu: peso úmido, ps: peso seco, J: Joule, N-AT: nitrogênio amoniacal total).

\begin{tabular}{|c|c|c|c|c|c|c|}
\hline ESPÉCIE & $\begin{array}{l}\text { IDADE } \\
\text { PESO }\end{array}$ & $\begin{array}{l}\text { TEMPERATURA } \\
\left({ }^{\circ} \mathrm{C}\right)\end{array}$ & $\begin{array}{l}\text { SALINIDADE } \\
(\%)\end{array}$ & $\begin{array}{l}\text { EXCREÇÃO AMÔNIA } \\
\text { (reportada) }\end{array}$ & 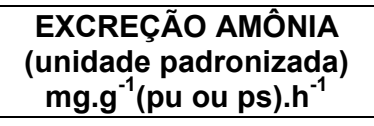 & REFERÊNCIA \\
\hline L. vannamei & $\begin{array}{l}\text { Pós-larva (pu) } \\
0,061 \pm 0,007 \mathrm{~g}\end{array}$ & 28 & 37 & $\begin{array}{l}\text { Média máxima s/ manuseio: } \\
4,19 \pm 0,25 \mu \mathrm{mol} \text { N-AT.g(pu })^{-1} \cdot \mathrm{h}^{-1} \\
\text { Após manuseio: } \\
\sim 7,3 \mu \mathrm{mol} \text { N-AT.g }(\mathrm{pu})^{-1} \cdot \mathrm{h}^{-1}\end{array}$ & $\begin{array}{l}0,06 \mathrm{mg} \mathrm{N}-\mathrm{AT} \cdot g(\mathrm{pu})^{-1} \cdot \mathrm{h}^{-1} \\
0,10 \mathrm{mg} \mathrm{N}-\mathrm{AT} \cdot \mathrm{g}(\mathrm{pu})^{-1} \cdot \mathrm{h}^{-1}\end{array}$ & $\begin{array}{l}\text { Gómez-Jimenez } \\
\text { et al. (2004) }\end{array}$ \\
\hline L. vannamei & $\begin{array}{l}\text { Pós-larva, peso médio (ps) } \\
\text { de PL1 a PL10 (dias após } \\
\text { metamorfose): } 0,3 \mathrm{mg}\end{array}$ & $28 \pm 0,1$ & $35 \pm 1$ & $\begin{array}{l}\text { Média máx.: } \\
0,042 \pm 0,004 \mathrm{~J} . d i a^{-1}\end{array}$ & $0,31 \mathrm{mg} \mathrm{N}-\mathrm{AT} \cdot \mathrm{g}(\mathrm{ps})^{-1} \cdot \mathrm{h}^{-1}$ & Brito et al. (2004) \\
\hline F.paulensis & $\begin{array}{l}\text { Pós-larva, peso médio (ps): } \\
\text { PL I }(108,7 \mu \mathrm{g}) \\
\text { PL II-III }(130,4 \mu \mathrm{g}) \\
\text { PL V-VI }(291,4 \mu \mathrm{g}) \\
\text { PL X-XII }(1493,6 \mu \mathrm{g})\end{array}$ & $26 \pm 1$ & $34 \pm 1$ & $\begin{array}{l}\left(\mu \mathrm{g} \mathrm{N}-\mathrm{AT} . \mathrm{ind}^{-1} \mathrm{~h}^{-1}\right) \\
0,0096(0,0013) \\
0,0152(0,0052) \\
0,0328(0,0075) \\
0,236(0,0624)\end{array}$ & $\begin{array}{l}\left.\text { [mg N-AT.g }(\mathrm{ps})^{-1} \cdot \mathrm{h}^{-1}\right] \\
0,09 \\
0,12 \\
0,11 \\
0,16\end{array}$ & $\begin{array}{l}\text { Lemos \& Phan } \\
(2001)\end{array}$ \\
\hline
\end{tabular}


Para o processo de maturação foi considerada a taxa de excreção de 0,31 mg N-AT.g ${ }^{-1} \cdot \mathrm{h}^{-1}$ de peso seco (ps), apresentada por Brito et al. (2004), por ser a máxima concentração verificada na bibliografia consultada, para uma pós-larva (PL) de peso médio entre PL1 e PL10 (dias após metamorfose) e uma densidade de 150 camarões $/ \mathrm{m}^{2}$ para ambos os sistemas, densidade representativa de sistemas comerciais semi-intensivos de cultivo (AMARAL et al., 2003).

A partir dos valores acima citados estimamos em 1,76mg de N-AT.dia ${ }^{-1}$ a produção máxima de amônia excretada para o sistema de aquários e em 1,54mg de N-AT.dia ${ }^{-1}$ para o sistema de tanques. Para a transformação dos valores de excreção apresentados por Brito et al. (2004) em Joules (J) para N-AT foi utilizado o equivalente energético de 20,5 J. $\mathrm{mg}^{-1} \mathrm{~N}-\mathrm{NH}_{3}$ (LUCAS, 1996 apud BRITO et al., 2004), como também utilizado pelos autores, mas inversamente (transformando N$\mathrm{NH}_{3}$ excretado em J), uma vez que toda amônia excretada (N-AT) era transformada em N-NH 3 para análise.

Foram também considerados os valores tóxicos de $\mathrm{CL}_{50}$ e os níveis de segurança para $\mathrm{N}-\mathrm{AT}, \mathrm{N}-\mathrm{NH}_{3}, \mathrm{~N}-\mathrm{NO}_{2}$ e $\mathrm{N}-\mathrm{NO}_{3}$, os quais podem ser observados na Tabela 2. Tais valores estão bem acima dos valores estimados como excreção máxima para o sistema de aquários $\left(0,006 \mathrm{mg} \mathrm{N}-\mathrm{AT} \cdot \mathrm{L}^{-1} \cdot \mathrm{dia}^{-1}\right)$ e para o sistema de tanques $\left(0,002 \mathrm{mg} \mathrm{N}-\mathrm{AT} \cdot \mathrm{L}^{-1} \cdot \mathrm{dia}^{-1}\right)$. Desta forma, foi preparada uma solução estoque de cloreto de amônia $\left(\mathrm{NH}_{4} \mathrm{Cl}\right)$ na concentração de $176,4 \mathrm{mg} \mathrm{N}-\mathrm{AT} . \mathrm{L}^{-1}$ ( $1,0 \mathrm{~g}$ de nitrogênio amoniacal corresponde a 3,78g de cloreto de amônio), e como sugerido por Daniels et al. (1992), iniciou-se a maturação dos sistemas através da adição inicial de $10 \%$ da concentração máxima requerida. 
Tabela 2. Concentração letal com mortalidade de $50 \%$ dos indivíduos $\left(\mathrm{CL}_{50}\right)$ para amônia, expressa como nitrogênio amoniacal total (N-AT), efeitos crônicos e níveis de segurança para $\mathrm{N}-\mathrm{AT}$, nitrito $\left(\mathrm{N}-\mathrm{NO}_{2}\right)$, nitrato $\left(\mathrm{N}-\mathrm{NO}_{3}\right)$ e amônia não ionizada $\left(\mathrm{N}-\mathrm{NH}_{3}\right)$ para diferentes estágios de Farfantepenaeus paulensis e Litopenaeus vannamei.

\begin{tabular}{|c|c|c|c|c|c|c|c|c|c|c|c|}
\hline ESPÉCIE & $\begin{array}{l}\text { IDADE/ } \\
\text { PESO }\end{array}$ & $\begin{array}{c}\mathrm{T} \\
\left({ }^{\circ} \mathrm{C}\right)\end{array}$ & $\begin{array}{l}S \\
(\%)\end{array}$ & $\mathrm{pH}$ & $\begin{array}{l}\text { EFEITOS } \\
\text { CRÔNICOS }\end{array}$ & $\begin{array}{l}\mathrm{CL}_{50-24 h} \\
\mathrm{~N}-\mathrm{AT} \\
(\mathrm{mg} / \mathrm{L})\end{array}$ & $\begin{array}{l}\mathrm{CL}_{50}-48 \mathrm{~h} \\
\mathrm{~N}-\mathrm{AT} \\
(\mathrm{mg} / \mathrm{L})\end{array}$ & $\begin{array}{l}\mathrm{CL}_{50}-72 \mathrm{~h} \\
\mathrm{~N}-\mathrm{AT} \\
(\mathrm{mg} / \mathrm{L})\end{array}$ & $\begin{array}{l}\mathrm{CL}_{50}-96 \mathrm{~h} \\
\mathrm{~N}-\mathrm{AT} \\
(\mathrm{mg} / \mathrm{L})\end{array}$ & $\begin{array}{c}\text { NÍVEIS DE SEGURANÇA } \\
-10 \% \text { DA CL } \text { CL-96h (SPRAGUE, } \text { (S71 apud OSTRENSKY \& } \\
\text { WASIELESKY, 1995) }\end{array}$ & REFERÊNCIAS \\
\hline \multirow{3}{*}{ F.paulensis } & \multirow{3}{*}{$\begin{array}{l}\text { Juvenil } \\
170 \pm 45 \mathrm{mg}\end{array}$} & \multirow{3}{*}{25} & \multirow{3}{*}{15} & \multirow{3}{*}{8} & $\begin{array}{l}\text { Crescimento } \\
\text { (N-AT: 0,91 mg/L) }\end{array}$ & - & - & - & - & - & \multirow{3}{*}{$\begin{array}{l}\text { Wasielesky, } \\
2000\end{array}$} \\
\hline & & & & & $\begin{array}{l}\text { Sobrevivência } \\
\left(\mathrm{N}-\mathrm{NO}_{2}: 10,2 \mathrm{mg} / \mathrm{L}\right)\end{array}$ & - & - & - & - & $\begin{array}{l}\text { N-NO } 2: 10,2 \mathrm{mg} / \mathrm{L} \\
\text { (CASTANÔ,, } 1997 \text { apud } \\
\text { WASIELESKY, 2000; SACHSIDA, } \\
1997 \text { apud WASIELESKY, 2000) }\end{array}$ & \\
\hline & & & & & $\begin{array}{l}\text { Crescimento } \\
\left(\mathrm{N}-\mathrm{NO}_{3}: 80,7 \mathrm{mg} / \mathrm{L}\right)\end{array}$ & - & - & - & - & $\mathrm{N}-\mathrm{NO}_{3}: 323 \mathrm{mg} / \mathrm{L}$ & \\
\hline \multirow{3}{*}{ F.paulensis } & Pós-larva & & & & - & 24,19 & 8,59 & 5,65 & 5,49 & $\begin{array}{l}\mathrm{N}-\mathrm{AT}: 0,55 \mathrm{mg} / \mathrm{L} \\
\mathrm{N}-\mathrm{NH}_{3}: 0,03 \mathrm{mg} / \mathrm{L}\end{array}$ & \multirow{3}{*}{$\begin{array}{l}\text { Ostrensky \& } \\
\text { Wasielesky, } \\
1995\end{array}$} \\
\hline & $\begin{array}{l}\text { Juvenil } \\
5,45 \pm 0,4 \mathrm{~g}\end{array}$ & 25 & 28 & 8,10 & - & 51,87 & 43,11 & 40,05 & 38,72 & $\begin{array}{l}\mathrm{N}-\mathrm{AT}: 3,87 \mathrm{mg} / \mathrm{L} \\
\mathrm{N}-\mathrm{NH}_{3}: 0,11 \mathrm{mg} / \mathrm{L}\end{array}$ & \\
\hline & $\begin{array}{l}\text { Adulto } \\
31,4 \pm 1,3 \mathrm{~g}\end{array}$ & & & & - & 61,63 & 50,51 & 46,57 & 42,49 & - & \\
\hline L.vannamei & $\begin{array}{l}\text { Juvenil } \\
22 \pm 42,2 \mathrm{~mm}\end{array}$ & 23 & 35 & 8,05 & - & 68,75 & 53,84 & 44,93 & 39,54 & $\begin{array}{l}\mathrm{N}-\mathrm{AT}: 3,25 \mathrm{mg} / \mathrm{L} \\
\mathrm{N}-\mathrm{NH}_{3}: 0,16 \mathrm{mg} / \mathrm{L}\end{array}$ & $\begin{array}{l}\text { Lin \& Chen, } \\
2001\end{array}$ \\
\hline
\end{tabular}


Após $24 \mathrm{~h}$ foram feitas análises de amônia, segundo o método de Koroleff (1969, 1970 apud HANSEN \& KOROLEFF, 1999) e nitrito, segundo Bendschneider \& Robinson (1952) e, Aminot \& Chaussepied (1983) (apud BAUMGARTEN et al., 1996). Foram coletadas amostras de água em triplicata em ambos os sistemas, antes e durante o processo de maturação.

Seguindo o procedimento descrito por DANIELS et al. (1992), quando as concentrações de $\mathrm{N}-\mathrm{AT}$ e $\mathrm{N}-\mathrm{NO}_{2}$ observadas estavam presentes ainda em quantidades próximas das quantidades adicionadas, não era aplicado $\circ \mathrm{NH}_{4} \mathrm{Cl}$ e a concentração era checada novamente após $24 \mathrm{~h}$. No caso dos compostos estarem em baixas concentrações, era adicionado novamente a mesma quantidade de $\mathrm{NH}_{4} \mathrm{Cl}$. A adição de $\mathrm{NH}_{4} \mathrm{Cl}$ na quantidade acima de $10 \%$ da concentração máxima requerida só teve continuidade quando as concentrações de $\mathrm{N}-\mathrm{AT}$ e $\mathrm{N}-\mathrm{NO}_{2}$ não foram detectadas em $24 \mathrm{~h}$, quando então, a quantidade adicionada foi dobrada.

A cada nível de $\mathrm{NH}_{4} \mathrm{Cl}$ consumido em $24 \mathrm{~h}$ foi adicionado uma quantidade maior que a anterior, até que a carga máxima requerida tivesse sido consumida em 24 horas. Tal procedimento foi realizado até os sistemas consumirem $100 \%$ da amônia requerida em $24 \mathrm{~h}$, além disto, foram adicionados até $300 \%$ da amônia necessária para maturação a fim de verificar a eficácia do sistema e, em função de que, na presença dos camarões, a entrada de nitrogênio nos sistemas dar - se ia também via degradação de ração e fezes. A adição de $\mathrm{NH}_{4} \mathrm{Cl}$ na quantidade de $300 \%$ da amônia necessária para maturação deu-se até a chegada das pós larvas do camarão L. vannamei. Desta forma, foram feitas adições de $10 \%, 20 \%, 30 \%$, $40 \%, 50 \%, 60 \%, 70 \%, 80 \%, 120 \%, 160 \%, 200 \%$ e $300 \%$ das concentrações máximas requeridas nos sistemas. 
Durante o processo de maturação, temperatura $\left(\mathrm{T}^{\circ} \mathrm{C}\right)$, salinidade $(\mathrm{S} \%$ o $)$ e $\mathrm{pH}$ foram mantidos em $30^{\circ} \mathrm{C}, 35 \%$ e $7-8$, respectivamente, sendo feito, diariamente, o monitoramento destes parâmetros. A salinidade foi verificada utilizando-se refratômetro manual (Atago, S/Mill) e o pH por meio de peagâmetro digital (Methrom, Modelo 744). Adicionou-se, conforme necessidade, água destilada com a finalidade de suprir a evaporação e controlar a variação da salinidade. Durante todo o trabalho, a adição de água foi feita na porção de saída da água, do filtro biológico para os tanques e/ou aquários, a fim de minimizar o contato com o substrato, pois as bactérias presentes no biofiltro são sensíveis à pequenas variações de salinidade e temperatura (DANIELS et al. 1992).

A maturação dos filtros biológicos teve duração de 28 dias para alcançar $120 \%$ da concentração requerida e mais 6 dias até $300 \%$. Em seguida, as póslarvas de L. vannamei foram distribuídas em ambos sistemas.

\section{3. Cultivo dos organismos experimentais}

Foram recebidas, via aérea, 3.000 pós-larvas de L. vannamei, oriundas da Larvi Aqüicultura Ltda. (Barreiras, Macau, RN). Os indivíduos estavam acondicionados em saco plástico com 18L de água à 35\% de salinidade, saturada em oxigênio e com alimento vivo (nauplios de Artemia salina, 60 nauplios/PL), sendo a temperatura de embarque $21^{\circ} \mathrm{C}$.

No Laboratório de Aqüicultura Marinha do Instituto Oceanográfico (LAMIO), Universidade de São Paulo (USP), localizado em São Paulo, aplicou-se aeração constante à água e foi feita a aclimatação dos indivíduos (Figura 3), elevando-se $1^{\circ} \mathrm{C}$ a cada $30 \mathrm{~min}$., sendo que a temperatura de chegada foi de $24^{\circ} \mathrm{C}$ 
e a temperatura dos tanques e aquários era $30^{\circ} \mathrm{C}$. Segundo Wyban et al. (1995), para camarões até $11 \mathrm{~g}$ da espécie $L$. vannamei, a temperatura ótima, na qual o crescimento é mais acelerado e eficiente, pode ser até maior que $30^{\circ} \mathrm{C}$, além disto, a temperatura acelera o metabolismo dos organismos cultivados, e conseqüentemente, o processo de liberação das fezes.

Em seguida os indivíduos foram contados com o auxílio de uma tela de nylon e alocados nos tanques e aquários, considerando-se a densidade de 150 indivíduos $/ \mathrm{m}^{2}$, sendo que um tanque foi definido como estoque e recebeu a densidade de 1350 indivíduos $/ \mathrm{m}^{2}$. As pós-larvas restantes foram acondicionadas em tanques de plástico a uma densidade de $50 \mathrm{PLs} / \mathrm{L}$, representativa da fase comercial de berçário, com aeração constante, troca de água a cada dois dias e sem controle da temperatura, permanecendo com médias (desvios-padrão) de $\mathrm{T}^{\circ} \mathrm{C}$ em 23,04 (0,74), S\% em 35,66 $(0,17)$ e pH em 7,81 $(1,27)$.

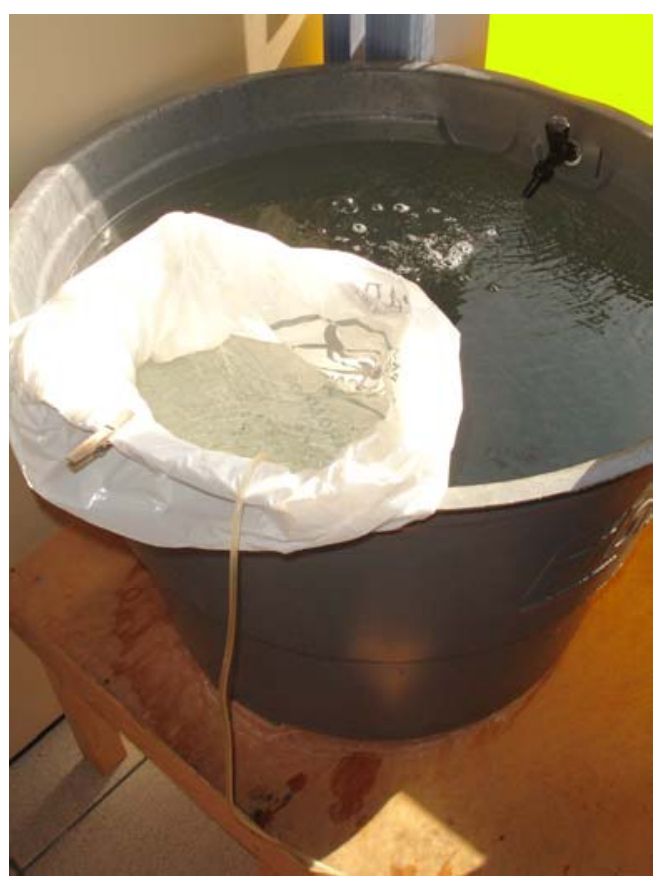

Figura 3. Aclimatação das pós-larvas de Litopenaeus vannamei. 
Os organismos alocados nos sistemas foram mantidos sob aeração constante, temperatura de $30^{\circ} \mathrm{C}$, salinidade de $35 \%$, $\mathrm{pH}$ entre 7,5 e 8,5 e fotoperíodo de $12 \mathrm{~h}$ claro: $12 \mathrm{~h}$ escuro. A iluminação era natural embora reduzida durante o dia (tanques escuros de polietileno e aquários recobertos com plástico preto), para que o ambiente se aproximasse o mais próximo possível do habitat natural dos camarões em cativeiro.

A alimentação diária fornecida ad libitum às pós-larvas consistia em ração comercial com teor protéico de 50\%, específica para a fase pós-larval (Epibal 500, Nexco). O alimento era fornecido em 3 ofertas (9h, 15h, 21h), totalizando $200 \%$ do peso úmido médio dos camarões, sendo a oferta noturna de maior peso. Para definição da quantidade diária de ração oferecida, após 10 dias da chegada das pós-larvas ao laboratório, foi determinado o peso úmido e seco dos animais em estudo, utilizando 5 réplicas de 40 indivíduos cada. Os indivíduos foram cuidadosamente separados com o auxílio da tela de nylon, lavados com água destilada para retirada do sal e para retirada do excesso de água foi utilizado papel absorvente. As amostras foram pesadas (peso úmido: pu) e, posteriormente, colocadas em estufa à $90^{\circ} \mathrm{C}$ para evaporação da água até peso constante. $\mathrm{A}$ quantidade de ração oferecida foi ajustada visualmente conforme o excesso ou falta da mesma. Como a ração oferecida era função do consumo, a relação entre biomassa corporal e consumo de ração foi verificada.

Após 21 dias de cultivo passou-se para densidades de 525 indivíduos $/ \mathrm{m}^{2}$ (tanques) e 400 indivíduos $/ \mathrm{m}^{2}$ (aquários), mantendo-se a densidade do tanqueestoque (1350 indivíduos $/ \mathrm{m}^{2}$ ), a fim de garantir a sobrevivência de organismos para os testes de digestibilidade. Quando as pós-larvas alcançaram 63 dias, a 
primeira ração foi substituída por outra também comercial com teor protéico de 40\% (Potimar 40PL, Guabi), aos 76 dias iniciou-se a utilização de ração com maior diâmetro e mesmo teor protéico (40\%), para camarões a partir de 1g (Potimar 40J, Guabi), e com 125 dias passou-se para ração com 35\% de proteína bruta (Potimar 35J, Guabi). As substituições foram graduais e, durante a transição, como recomendado por Wyk (1999), as rações eram misturadas para os camarões disponibilizarem de tempo suficiente para adaptarem-se ao novo alimento, levando 15 dias para total troca e aclimatação dos camarões à cada nova ração.

Com relação à biometria destes animais, foram realizadas seis pesagens durante o cultivo para crescimento dos organismos, com intervalos aproximados de 30 dias e determinou-se a taxa de crescimento individual (TC) como descrito a seguir:

$$
\mathrm{TC}=\frac{\text { peso final do camarão }(\mathrm{g})-\text { peso inicial do camarão }(\mathrm{g})}{\text { período de cultivo (dias) }}
$$

Durante o processo de pesagem, os camarões foram cuidadosamente retirados dos tanques e aquários com o auxílio de uma rede e colocados em caixas plásticas contendo água, proveniente do mesmo sistema no qual os camarões à pesar estavam alocados, e aeração constante. As caixas eram levadas próximas à balança analítica (Sartorius ${ }^{\circledR}$, precisão de $0,1 \mathrm{mg}$ ) e, individualmente, os camarões eram novamente coletados com a rede. Retirava-se o excesso de água com o auxílio de um pano macio para, em seguida, pesá-los.

Na biometria das pós-larvas de 70 dias retirou-se uma amostra aleatória de indivíduos dos tanques e outra dos aquários, que foram pesadas 
separadamente. Após a biometria de PL70 as pós-larvas foram realocadas objetivando a redução do canibalismo, sendo agrupadas em conjuntos de tamanhos pequenos $(0,000 \mathrm{~g}$ a $0,100 \mathrm{~g})$ e grandes $(0,501 \mathrm{~g}$ a $2,500 \mathrm{~g})$ nos aquários, separadamente, e médios $(0,101 \mathrm{~g}$ a $0,500 \mathrm{~g})$ nos tanques. A partir da biometria de 106 dias, todos os indivíduos de cada sistema foram pesados.

Os animais foram cultivados até a chegada das dietas experimentais e início da aclimatação, período que durou 207 dias (aproximadamente 7 meses). Durante este período, a sobrevivência e as densidades também foram estabelecidas para cada sistema. No cálculo da sobrevivência não foram contabilizados os animais que apresentaram sintomas patogênicos, e.g. musculatura esbranquiçada, características de NIM (Necrose Infecciosa Muscular) (Fonseca et. al, 2004), ou ainda os que pulavam dos sistemas. Os animais com sintomatologia patogênica forma retirados dos sistemas.

\section{4. Formulação e fabricação das dietas experimentais}

Foram escolhidos ingredientes (Figura 4) comumente utilizados na confecção de rações para aqüicultura (HERTRAMPF \& PIEDAD-PASCUAL, 2000) na formulação e fabricação das dietas experimentais: farinha de trigo, glúten de milho, farinha de peixe nacional, quirera de arroz, farinha de peixe peruana e três diferentes produtos de soja: farelo de soja (FS), farelo de soja texturizado (FST) e farelo de soja micronizado (FSM), sendo que os três diferentes tipos de soja foram os ingredientes a serem testados.

Atualmente o Brasil é o segundo produtor mundial de soja (EMBRAPA, 2008), a qual sabe-se ter elevado conteúdo protéico (HERTRAMPF \& PIEDAD- 
PASCUAL, 2000) com o melhor perfil de aminoácidos comparado à outros vegetais, embora seu teor protéico ainda seja inferior às farinhas de peixe (SWICK, 2002, 2007), no entanto, variações no processamento da soja podem acarretar em aumento do valor nutricional (BELLAVER \& SNIZEK; 1999; MENDES et al., 2004; SWICK, 2007).

Para a formulação de dietas que atendessem aos requerimentos nutricionais dos camarões, foi necessário o conhecimento da composição centesimal dos ingredientes a serem utilizados e do conteúdo energético dos mesmos (Tabela 3). As análises de proteína bruta, extrato etéreo, cinzas e fibra bruta dos ingredientes foram feitas pelo Laboratório CBO - Assessoria e Análise (Campinas, SP), segundo os métodos do Compêndio Brasileiro de Alimentação Animal (CBAA, 2005).

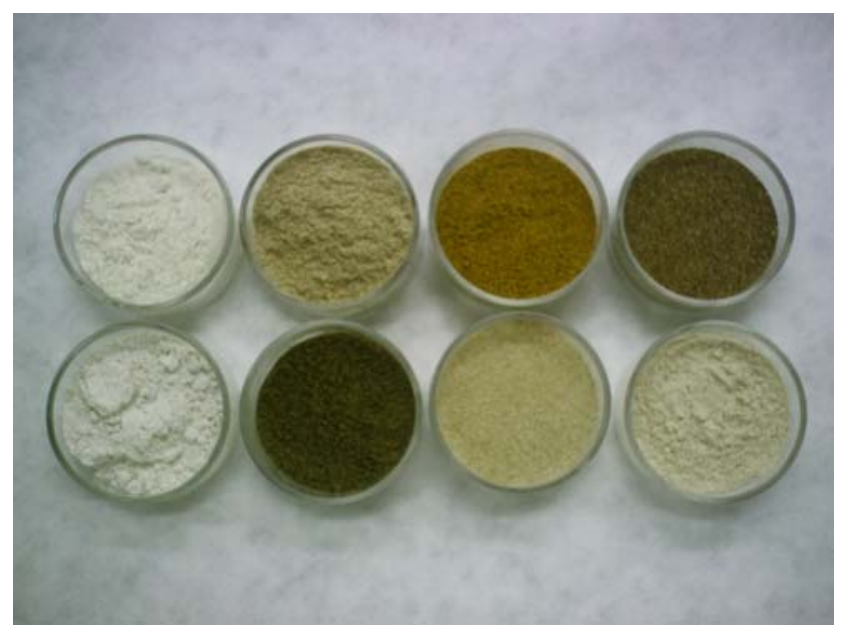

Figura 4. Ingredientes utilizados na confecção das dietas-teste (da esquerda para direita, de cima para baixo): farinha de trigo, farelo de soja (FS), glúten de milho, farinha de peixe nacional, quirera de arroz, farinha de peixe peruana, farelo de soja texturizado (FST) e farelo de soja micronizado (FSM). 
Para o conteúdo protéico foi utilizado o método de Kjeldahl, com a multiplicação do nitrogênio total por 6,25. O conteúdo energético foi analisado no LAM-IOUSP, por meio do método de combustão úmida (KARZINKIN \& TARKOVSKAYA, 1964), com correção de $20 \%$ para proteína segundo ELLIOT \& DAVISON (1975 apud LEMOS \& PHAN, 2001), pois o método considera apenas $80 \%$ da combustão protéica. O carboidrato foi estimado por diferença entre a energia total e as energias de lipídeos e proteínas.

Tabela 3. Composição centesimal e energia dos ingredientes (matéria úmida) utilizados na fabricação das dietas experimentais. Resultados expressos como média (desvio padrão) ( $n=2$, exceto para Energia, onde $n=3)$.

\begin{tabular}{|c|c|c|c|c|c|c|}
\hline Ingrediente & $\begin{array}{l}\text { Proteína } \\
\text { Bruta (\%) }\end{array}$ & $\begin{array}{c}\text { Extrato } \\
\text { Etéreo (\%) }\end{array}$ & Cinzas (\%) & $\begin{array}{c}\text { Fibra } \\
\text { Bruta (\%) }\end{array}$ & Energia (cal/g) & $\begin{array}{c}\text { Carboidrato } \\
(\%)\end{array}$ \\
\hline Farinha de trigo & $10,41(0,22)$ & $1,05(0,04)$ & $0,64(0,03)$ & $0,21(0,01)$ & $3473(75,1)$ & 68,16 \\
\hline Glúten de milho & $67,02(0,27)$ & $2,99(0,10)$ & $3,36(0,02)$ & $1,01(0,04)$ & $4990(21,1)$ & 23,37 \\
\hline $\begin{array}{l}\text { Quirera de } \\
\text { arroz }\end{array}$ & $9,19(0,10)$ & $1,97(0,15)$ & $0,78(0,01)$ & $0,26(0,02)$ & $3541(49,8)$ & 69,36 \\
\hline $\begin{array}{c}\text { Farinha de } \\
\text { peixe nacional }\end{array}$ & $54,54(0,55)$ & $3,22(0,18)$ & $28,19(0,04)$ & $2,40(0,04)$ & $3420(51,2)$ & 1,57 \\
\hline $\begin{array}{c}\text { Farinha de } \\
\text { peixe peruana }\end{array}$ & $68,67(0,11)$ & $6,98(0,25)$ & $16,28(0,12)$ & $0,12(0,01)$ & $4003(87,8)$ & -2 \\
\hline $\begin{array}{l}\text { Farelo de soja } \\
\text { com casca (FS) }\end{array}$ & $46,35(0,28)$ & $3,37(0,14)$ & $6,74(0,26)$ & $5,26(0,06)$ & $4021(143)$ & 27,11 \\
\hline $\begin{array}{c}\text { Farelo de soja } \\
\text { texturizado } \\
\text { (FST) }\end{array}$ & $54,14(0,04)$ & $0,79(0,04)$ & $5,78(0,01)$ & $2,52(0,16)$ & $4033(42,2)$ & 22,66 \\
\hline $\begin{array}{l}\text { Farelo de soja } \\
\text { micronizado } \\
\text { (FSM) }\end{array}$ & $48,74(0,13)$ & $1,63(0,12)$ & $7,23(0,21)$ & $3,42(0,07)$ & $3928(85,3)$ & 25,55 \\
\hline
\end{tabular}

${ }^{1}$ Estimativa obtida por diferença de conteúdo energético entre Energia total, e lipídeos e proteínas, corrigida para proteínas (ELLIOT \& DAVISON, 1975 apud LEMOS \& PHAN, 2001)

${ }^{2}$ Não detectável. 
Foram formuladas e fabricadas três dietas experimentais (FS, FST e FSM) pelo Laboratório de Ração e Nutrição de Camarão Marinho (LRNCM), do Instituto de Ciências do Mar, da Universidade Federal do Ceará (LABOMAR - UFC), baseadas prioritariamente no conteúdo de proteína e energia (isoprotéicas e isocalóricas), mas também nos demais parâmetros da composição centesimal dos ingredientes, com auxílio do programa UNEForm, (www.assc.une.edu.au). A formulação do percentual de ingredientes nas dietas (Tabela 4) objetivou manter as proporções entre energia, conteúdo protéico, lipídeos, cinzas e a relação proteína/ energia (P/E), variando entre elas apenas o tipo de proteína de soja: FS, FST e FSM. A composição centesimal das dietas pode ser observada na Tabela 5, análises segundo CBAA (2005) e o tamanho dos pellets na Figura 5.

Além dos ingredientes citados anteriormente, foi adicionado às dietas experimentais: óleo de peixe, lecitina de soja, colesterol, óxido crômico (marcador), sal, vitaminas e minerais, aglutinante sintético, atrativo e fosfato dicálcico. O marcador óxido crômico foi adicionado na quantidade recomendada $(<1 \%)$ e comumente utilizada em experimentos de digestibilidade para camarões e peixes (TACON \& RODRIGUES, 1984; SUGIURA, 2000; SMITH \& TABRETT, 2003; DIVAKARAN et al. 2000 apud DIVAKARAN, 2005). 
Tabela 4. Formulação das dietas-teste: farelo de soja (FS), farelo de soja texturizado (FST) e farelo de soja micronizado (FSM).

\begin{tabular}{lccc}
\hline \multicolumn{1}{c}{ Ingredientes $^{\prime}$} & FS (\%) & FST (\%) & FSM (\%) \\
\hline Farinha de trigo* $^{*}$ & 22,00 & 22,00 & 22,00 \\
Quirera de arroz $^{1}$ & 14,02 & 19,87 & 16,89 \\
Farinha de peixe peruana $^{2}$ & 15,0 & 15,0 & 15,0 \\
Farinha de peixe nacional $^{3}$ & 2,00 & 2,00 & 2,00 \\
Glúten de milho* $^{*}$ & 2,00 & 2,00 & 2,00 \\
Farelo de soja* $^{*}$ & 37,2 & 0,00 & 0,00 \\
Farelo de soja texturizado* $^{*}$ & 0,00 & 30,9 & 0,00 \\
Farelo de soja micronizado* $^{*}$ & 0,00 & 0,00 & 34,9 \\
Óleo de peixe $^{4}$ & 1,50 & 2,00 & 1,00 \\
Lecitina de soja $^{5}$ & 2,00 & 2,00 & 2,00 \\
Colesterol $^{6}$ & 0,15 & 0,15 & 0,15 \\
Óxido de cromo $^{7}$ & 0,50 & 0,50 & 0,50 \\
Sal (NaCl) $^{*}$ & 0,50 & 0,50 & 0,50 \\
Premix vitamínico-mineral $^{8}$ & 1,00 & 1,00 & 1,00 \\
Aglutinante sintético $^{9}$ & 0,50 & 0,50 & 0,50 \\
Atrativo $^{10}$ & 0,40 & 0,40 & 0,40 \\
Fosfato dicálcico* $^{*}$ & 1,20 & 1,20 & 1,20 \\
\hline
\end{tabular}

* Ingredientes cedidos pela Purina, Agribrands do Brasil Ltda.(fabricante desconhecido).

${ }^{1}$ Usina Catende, Catende, PE.

${ }^{2}$ Pesquera Capricornio S.A., Lima, Peru.

${ }^{3}$ ETNA Agro Indústria Ltda., Capela de Santana, RS.

${ }^{4} 98,0 \%$ extrato etéreo (EE); $8.620 \mathrm{Kcal} / \mathrm{kg}$ energia bruta (EB).

${ }^{5} 100 \%$ EE; $7.590 \mathrm{Kcal} / \mathrm{kg} \mathrm{EB}$.

${ }^{6}$ Cholesterol XG, Solvay Pharmaceuticals BV/NL. 91\% de pureza.

${ }^{7}$ Chromiun oxide, Merck, Germany.

${ }^{8}$ Rovimix Camarão Intensivo. DSM Produtos Nutricionais Brasil Ltda., São Paulo, SP. Níveis de garantia por kg: vitamina A, 1.250.000 Ul; vitamina D3, $350.000 \mathrm{Ul}$; vitamina E, $25.000 \mathrm{Ul}$; vitamina $\mathrm{K} 3,500,0 \mathrm{mg}$; vitamina $\mathrm{B} 1,5.000,0 \mathrm{mg}$; vitamina B2, 4.000,0 mg; vitamina B6; $10,0 \mathrm{mg}$; ácido nicotinico, 15.000,0 mg; ácido pantotênico, 10.000,0 mg; biotina, 150,0 mg; ácido fólico, 1.250,0 
mg; vitamina C, 25.000,0 mg; colina, 50.000,0 mg; colina, 50.000,0 mg; inositol, 20.000,0 mg; ferro $2.000,0 \mathrm{mg}$; cobre, 3.500,0 mg; cobre quelado, 1.500,0 mg; zinco, 10.500,0 mg; zinco quelado, $4.500,0 \mathrm{mg}$; manganês, 4.000,0 mg; selênio, $15,0 \mathrm{mg}$; selênio quelado, $15,0 \mathrm{mg}$; iodo, 150,0 mg; cobalto, 30,0 mg; cromo 80,0 mg; veículo q.s.p., 1.000,0 g.

${ }^{9}$ Pegabind ${ }^{\mathrm{TM}}$, Bentoli Agrinutrition, Texas, EUA. Aglutinante sintético a base de uréia formaldeído.

${ }^{10}$ Aquasavor $^{\mathrm{TM}}$, Bentoli Agrinutrition, Texas, EUA.

Tabela 5. Composição centesimal, energética e a relação proteína/energia ( $P: E)$ das dietas-teste (matéria úmida): farelo de soja (FS), farelo de soja texturizado (FST) e farelo de soja micronizado (FSM). Resultados expressos como média (desvio padrão) ( $n=2$, exceto para umidade, onde $n=5$ e óxido crômico, $n=3$ ).

\begin{tabular}{lccc}
\hline & FS & FST & FSM \\
\hline Proteína bruta (\%) & $31,79(0,31)$ & $32,61(0,10)$ & $31,02(0,10)$ \\
Lipídeos (\%) & $7,87(0,45)$ & $9,21(0,27)$ & $7,65(0,15)$ \\
Cinzas (\%) & $8,98(0,21)$ & $8,57(0,08)$ & $8,71(0,04)$ \\
Fibra bruta (\%) & $1,87(0,14)$ & $0,69(0,01)$ & $1,11(0,03)$ \\
Umidade (\%) & $9,31(0,01)$ & $7,58(0,00)$ & $9,78(0,00)$ \\
P:E (mg/Kcal) & $76,69(0,78)$ & $76,99(0,07)$ & $75,84(0,19)$ \\
Energia (Kcal/g) & $4,15(0,00)$ & $4,24(0,01)$ & $4,09(0,00)$ \\
$\mathrm{Cr}_{2} \mathrm{O}_{3}(\%)$ & $0,27(0,01)$ & $0,30(0,01)$ & $0,29(0,01)$ \\
\hline
\end{tabular}

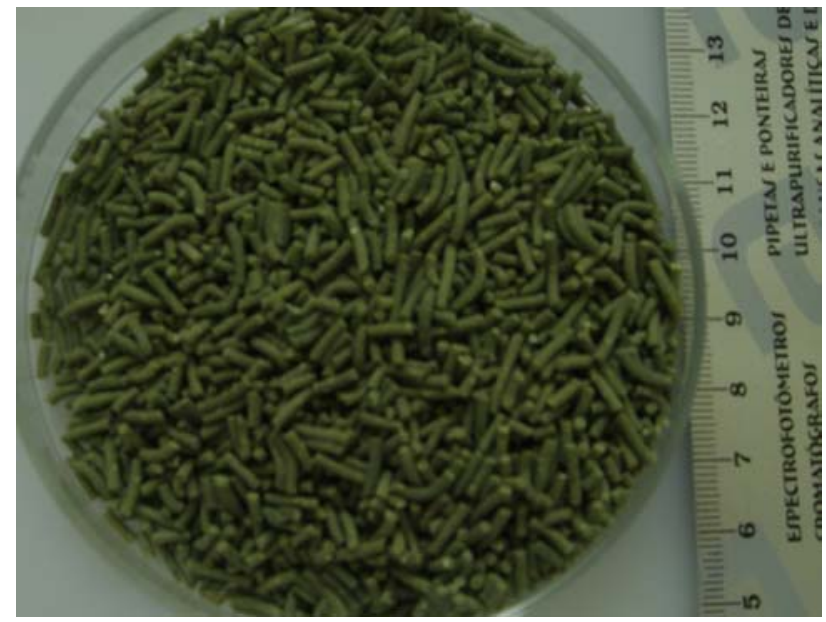

Figura 5. Tamanho dos pellets das dietas-teste: $1,55 \mathrm{~mm}$ de diâmetro e de 3 a 10 $\mathrm{mm}$ de comprimento. 
A fabricação das dietas seguiu as seguintes etapas: moagem (moinho tipo Willye, modelo MA-680, Marconi Equipamentos para Laboratório Ltda., Piracicaba, $\mathrm{SP}$ ) do farelo de soja, quirera de arroz e farinha de peixe nacional em malha com $600 \mu \mathrm{m}$. Subseqüentemente, estes ingredientes e os demais (farinha de peixe peruana, farelo de soja texturizado, farelo de soja micronizado, farinha de trigo e glúten de milho) foram individualmente peneirados em malha de $250 \mu \mathrm{m}$. Após a moagem, todos os ingredientes sólidos e líquidos foram pesados em balança eletrônica de precisão (Ohaus Adventurer, Toledo do Brasil, São Paulo, SP) e misturados em uma batedeira planetária industrial para massas (G. Paniz, Modelo BP-12 super, Caxias do Sul, RS) durante 10 minutos, sendo cada dieta com um ingrediente diferente de soja (FS, FST e FSM). Após este período, água doce à $92^{\circ} \mathrm{C}$ foi adicionada à mistura de ingredientes na proporção de $2,0: 1,5$. Os ingredientes foram misturados por um tempo adicional de 10 minutos até a formação de um bolo. O bolo de ingredientes foi então transferido para uma cuscuzeira e mantido sob cozimento à vapor durante $40 \mathrm{~min}$. $\mathrm{O}$ bolo cozido foi submetido à extrusão em um moedor industrial para carnes (C.A.F., modelo CAF32, Rio Claro, SP) equipado com uma matriz de 2,0 $\mathrm{mm}$. Durante a extrusão à frio houve a formação de uma massa na forma de cordão, a qual foi distribuída em bandejas de aço inox para secagem à $65^{\circ} \mathrm{C}$ em estufa com circulação e renovação de ar (estufa de secagem especial, Modelo MA-035/3, Marconi Equipamentos para Laboratório Ltda., Piracicaba, SP) durante $5 \mathrm{~h}$. A massa foi revirada a cada $2 \mathrm{~h}$ de secagem para alcançar umidade homogênea. Estes procedimentos deram-se para cada dieta. Findo o processo de secagem as dietas foram cortadas em pellets cônicos com 5,0 cm de comprimento em um multiprocessador, embaladas em 
sacos plásticos, identificadas e armazenadas sob temperatura de $-22^{\circ} \mathrm{C}$ até $\mathrm{O}$ envio para o LAM-IOUSP, em São Paulo.

\section{5. Teste de digestibilidade protéica}

\section{5. 1. Aclimatação às dietas experimentais}

Após a chegada das dietas experimentais, foi realizada a biometria dos camarões antes da aclimatação às dietas (pós-larvas de 217 dias) e a última da fase de cultivo com ração comercial. Em seguida, os animais do sistema de tanques foram realocados para densidades de 14,28 indivíduos $/ \mathrm{m}^{2}$, a fim de ficarem em densidades próximas do sistema de aquários (12,5 indivíduos $\left./ \mathrm{m}^{2}\right)$, sendo um camarão por aquário e 4 camarões por tanque em teste. O restante dos organismos foram dispostos todos em um tanque estoque (densidade: 50 indivíduos $/ \mathrm{m}^{2}$ ) e continuaram sendo alimentados com ração comercial. Após a biometria aguardou-se $48 \mathrm{~h}$ para recuperação dos animais ao estresse do manuseio e início da substituição da ração comercial pelas dietas experimentais e aclimatação às mesmas. Os animais apresentavam pesos médios de $14,9 \mathrm{~g}$ (aquários) e 17,8g (tanques).

Durante o período experimental (aclimatação às dietas e teste de digestibilidade), que teve duração total de 62 dias, temperatura, salinidade e $\mathrm{pH}$ foram mantidos constante, como em todo período de cultivo. Manteve-se também a aeração constante, fotoperíodo e oferta de alimento (9h, 15h, 21h), sendo que, nesta fase, a oferta diária de ração correspondia à 6,72\% e 5,17\% da biomassa corporal dos animais para aquários e tanques, respectivamente. 
A aclimatação às dietas durou 26 dias, destes, 8 dias foram de substituição gradual da ração comercial para as dietas experimentais e 18 dias somente de alimentação com dieta experimental. D’Abramo \& Castell (1997) recomendam 7 dias como tempo mínimo para aclimatação à dieta-teste e períodos mais prolongados para organismos de maior tamanho, como é o caso neste estudo. A substituição do alimento teve iníciou com $1 / 4$ de dieta experimental e $3 / 4$ de ração comercial, e a cada 2 dias a dieta experimental era aumentada e a ração comercial reduzida na mesma proporção. As dietas foram distribuídas alternadamente nos aquários, a fim de manter a homogeneidade da água em recirculação. Para cada dieta foram alimentados camarões em 5 aquários e em 1 tanque, e 1 aquário permaneceu sem animal para estimativa da perda de nutriente (proteína bruta) e marcador (óxido crômico) por lixiviação. Os aquários, tanques e frascos para pesagem das dietas foram marcados com cores distintas como na Figura 6.

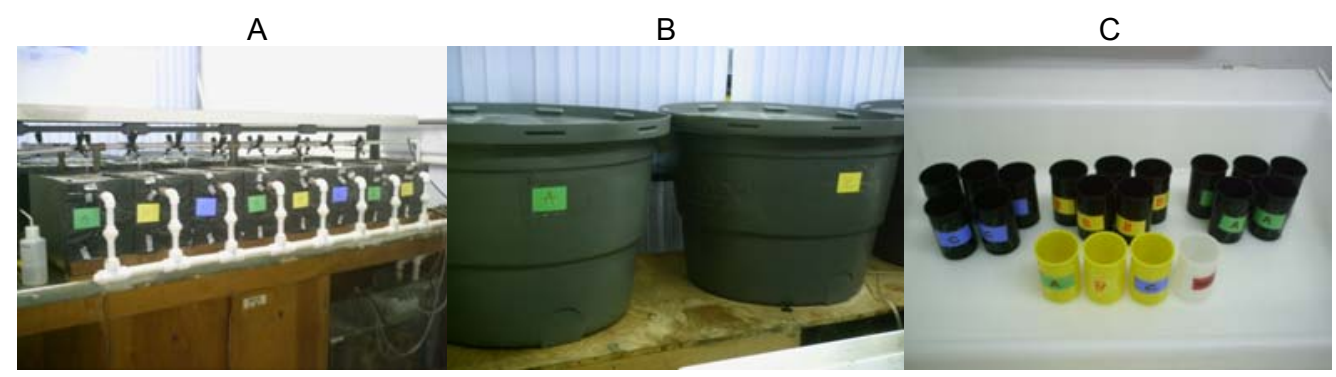

Figura 6. Sistemas de aquários $(A)$, tanques $(B)$ e recipientes de alimentação $(C)$ marcados para cada dieta.

Durante a substituição do alimento foram feitos testes visuais no sistema de aquários, com a finalidade de observar o tempo que os camarões levavam para iniciar a alimentação, sendo verificada uma média de 30 minutos. Este tempo foi 
utilizado para definição do período de oferecimento das dietas aos camarões e também da duração dos testes de lixiviação das dietas, realizados nos aquários. No mesmo período, foi feita a análise do peso seco das fezes, a fim de definir a quantidade de amostra úmida da mesma, necessária às análises químicas de cromo (Cr) e proteína bruta (PB).

Após a aclimatação foi realizada nova biometria ( $P L$ de 238 dias) e aguardou-se 7 dias para recuperação do estresse da manipulação e início do teste de digestibilidade, totalizando 18 dias de alimentação com as dietas experimentais antes do teste.

\section{5. 2. Rotina experimental}

O teste de digestibilidade foi realizado durante 36 dias em dias alternados para redução do estresse e recuperação dos animais, seguindo o cronograma demonstrado na Figura 7.

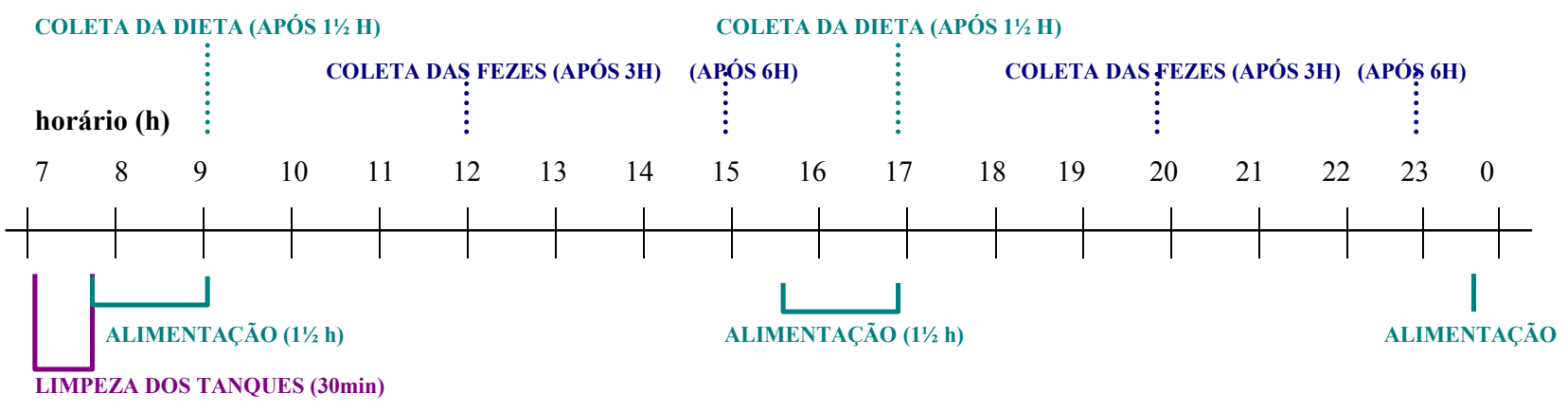

Figura 7. Cronograma da rotina em dia de teste de digestibilidade de dietas experimentais (FS, FST e FSM) para camarões Litopenaeus vannamei 
Inicialmente era feita a sifonagem (Figura 8) completa dos tanques e aquários para retirada das sobras de alimento, fezes e carapaças provenientes de muda. As unidades experimentais com muda eram anotadas e nesses locais, as amostras de fezes coletadas $48 \mathrm{~h}$ antes da ecdise eram descartadas e as amostras produzidas $36 \mathrm{~h}$ após a ecdise eram desconsideradas.

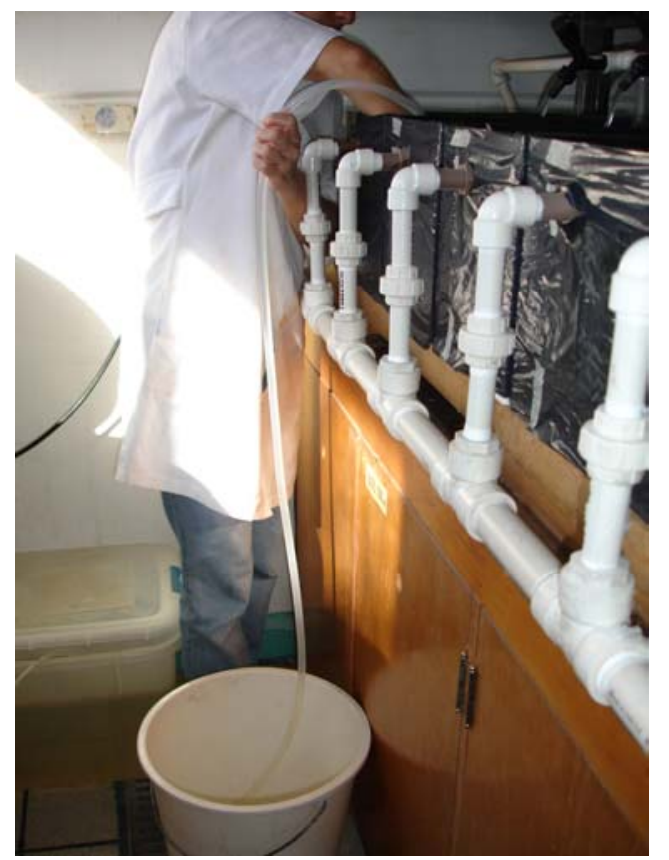

Figura 8. Sifonagem: processo utilizado na limpeza dos tanques e aquários.

Geralmente a ecdise acontece no período noturno para todas espécies de peneídeos investigadas e, em função deste processo, a alimentação dos camarões começa a ser alterada $36 \mathrm{~h}$ antes da noite em que ocorre a muda (DALL et al., 1990; DALL, 1992), por isso o descarte das amostras dos dois dias anteriores à visualização da carapaça, esta, geralmente encontrada no dia seguinte à noite de muda. A alimentação de camarões da espécie $P$. duorarum torna-se regular após 36h da ecdise (BURSEY \& LANE, 1971 apud DALL et al., 
1990) e para outros peneídeos, a alimentação não tem início até a entrada no estágio B do ciclo de muda, que acontece de $24 \mathrm{~h}$ a $36 \mathrm{~h}$ após a ecdise (DALL et al., 1990; DALL, 1992). Assim, considerou-se adequado excluir também as fezes produzidas em 36h após a muda.

Após a limpeza dos sistemas, as dietas experimentais eram oferecidas ad libitum (cerca de $4,9 \%$ e $3,9 \%$ da biomassa corporal dos animais nos aquários e tanques, respectivamente) aos camarões, durante 1h30min. Smith \& Tabrett (2004) observaram em $P$. monodon o início da alimentação após 5 min. da oferta de alimento, completando-se em $15 \mathrm{~min}$. No presente trabalho, foi verificado em testes visuais uma média de 30 min. para o início da alimentação, desta forma, a dieta permaneceu nos tanques durante $1 \mathrm{~h} 30 \mathrm{~min}$. a fim de encorajar o máximo consumo. Em seguida, as sobras de dieta eram retiradas por sifonagem, mas antes da retirada do alimento, eram observados e anotados os camarões que se alimentaram, tanto nos aquários, como nos tanques, por meio da visualização dos pellets, que tinham sua quantidade reduzida e se fragmentavam quando os camarões ingeriam alimento. Apenas as fezes dos camarões que se alimentavam foram coletadas.

Após $3 \mathrm{~h}$ da retirada do alimento, as primeiras fezes eram totalmente coletadas também por sifonamento, objetivando a redução da perda por lixiviação, como recomendado por D'Abramo \& Castell (1997) e Smith \& Tabrett (2004). Em seguida, as fezes eram dispostas em uma placa de Petri para retirada do excesso de água salgada e lavagem com água destilada para retirada do sal (Figura 9). Posteriormente, retirava-se o excesso de água destilada e com uma espátula as fezes eram armazenadas em tubos plásticos e congeladas. Nos aquários, as 
coletas foram feitas com o auxílio de uma canícula de vidro (Figura 9) e diretamente dispostas na placa de Petri, enquanto que nos tanques, as fezes, primeiramente, eram retiradas com uma mangueira de silicone e alocadas em um balde, de onde então, eram retiradas com um conta-gotas e dispostas na placa de Petri (Figura 10).

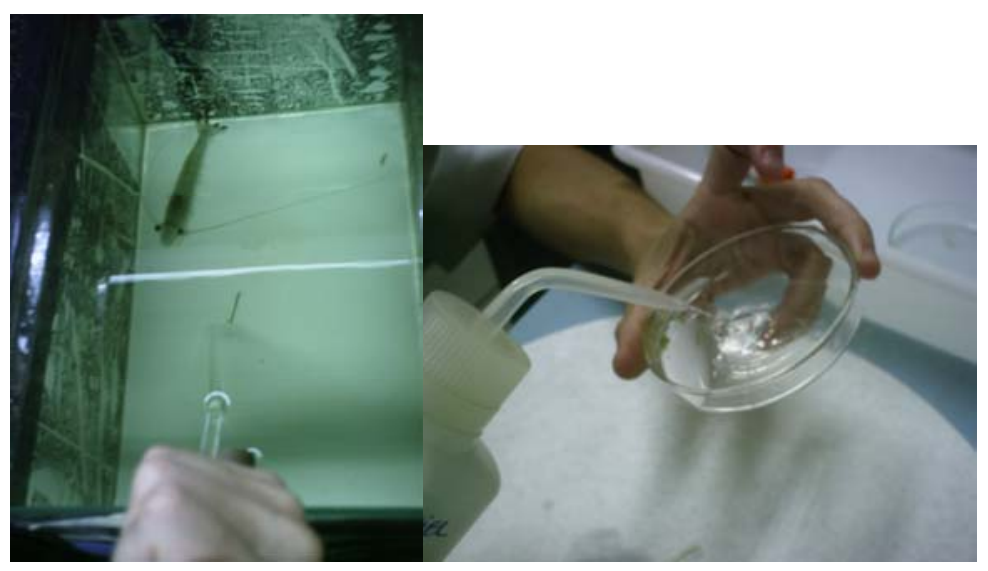

Figura 9. Coleta de fezes no sistema de aquários e posterior retirada do sal com água destilada durante o experimento de digestibilidade.

Após um novo período de $3 \mathrm{~h}$ (totalizando $6 \mathrm{~h}$ de intervalo entre as ofertas de alimento), se houvesse mais fezes nos sistemas estas eram novamente retiradas, lavadas e congeladas. Em seguida, nova alimentação era oferecida durante $1 \mathrm{~h} 30 \mathrm{~m}$ e seguia-se novamente o protocolo descrito anteriormente. Ao final da última coleta de fezes, era feita a terceira oferta de alimento, esta sem coleta de fezes. No dia seguinte, era apenas oferecida dieta 3 vezes ao dia (9h, 15h, 21h), sem coleta de fezes e sifonagens, como descrito na Figura 11. 


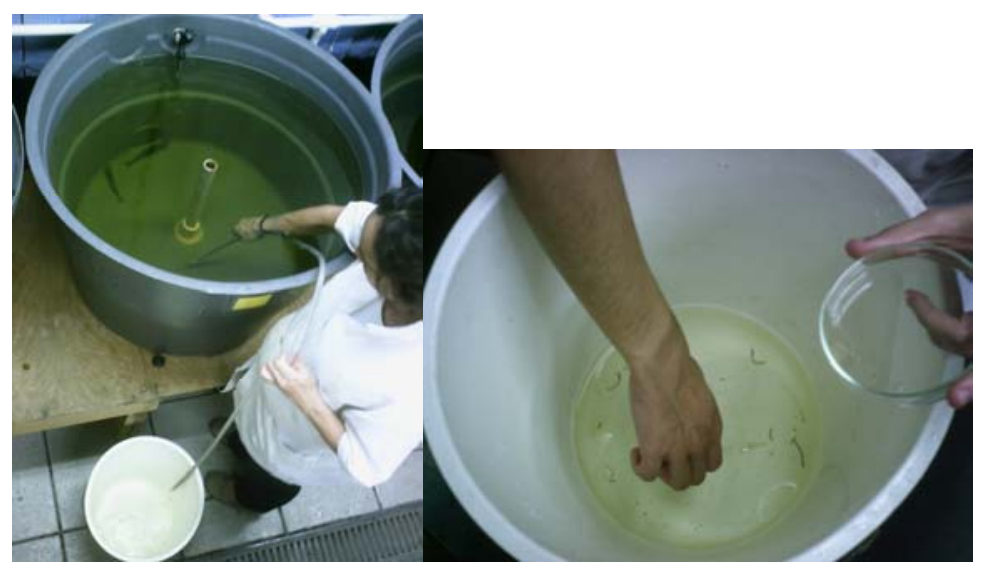

Figura 10. Coleta de fezes no sistema de tanques durante o experimento de digestibilidade.

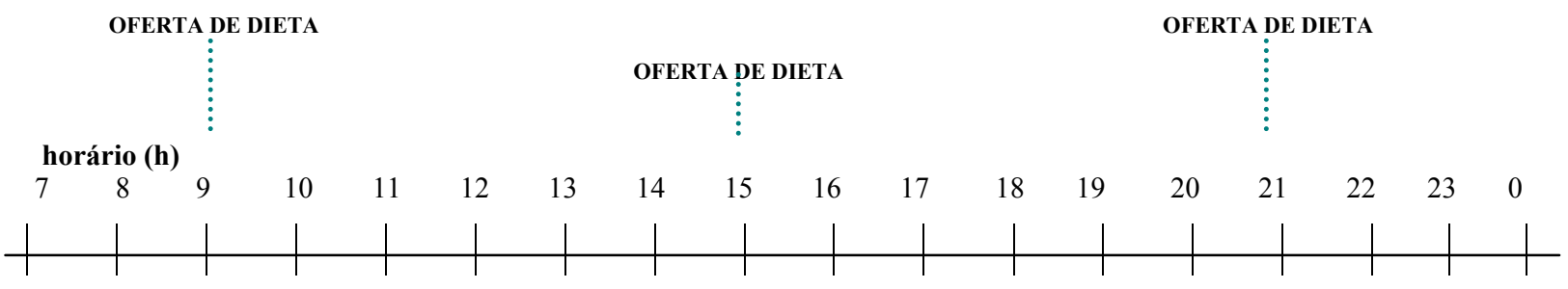

Figura 11. Cronograma da rotina para camarões Litopenaeus vannamei em dias sem de teste de digestibilidade.

Durante a noite, a coleta das fezes e a retirada das dietas eram realizadas sob intensidade luminosa mínima, com o auxilio de uma luminária, suficiente apenas para possibilitar o procedimento de coleta e evitar o comportamento de escape, típico desta espécie (WYBAN, 1995).

As fezes coletadas nos dias de teste eram armazenadas em frascos exclusivos de coleta, que no próximo dia de teste eram passadas para frascos de armazenamento, pois quando fosse necessário descartar amostras em função da muda, estas estariam em recipientes separados. 
A partir das concentrações de $\mathrm{Cr}$ e PB na dieta ingerida e nas fezes calculou-se a DAPB dos camarões alimentados com as três dietas (FS, FST e FSM) (ver item 2.5.4.).

\section{5. 3. Lixiviação das dietas}

Foram realizados testes de lixiviação de $\mathrm{PB}$ e $\mathrm{Cr}$, presentes nas dietas, visando quantificar mais precisamente o quanto destes compostos era realmente disponibilizado para os camarões. A partir dos testes visuais no sistema de aquários, com a finalidade de definir o tempo que os camarões levavam para iniciar a alimentação (média de $30 \mathrm{~min}$ ), estabeleceu-se a duração dos testes de lixiviação das dietas.

Os testes de lixiviação foram aplicados em aquários-controles, ou seja, que faziam parte do sistema de aquários, mas não continham animais. Para tanto, colocou-se nos aquários a mesma quantidade de dieta oferecida aos camarões durante 30 minutos. Em seguida, este material foi recolhido, lavado com água destilada para retirada do excesso de sal e congelado, procedimento semelhante ao descrito para coleta das fezes no aquário, como citado anteriormente. As amostras congeladas foram enviadas para as análises químicas descritas no item 2.5.4.

A partir das concentrações de $\mathrm{Cr}$ e PB nas dietas experimentais antes e após imersão durante 30 min., calculou-se a porcentagem de perda por lixiviação (L), segundo a fórmula: 
$L(\%)=\left(\frac{P S P B \text { ou PSCr antes da imersão }(\mathrm{g})-\text { PSPB ou PSCr após imersão }(\mathrm{g})}{\text { PSPB ou PSCr antes da imersão }(\mathrm{g})}\right) \times 100$

Onde, PSPB é a concentração de proteína bruta (PB) em peso seco (PS) de dieta, e PSCr é a concentração de cromo (Cr) em peso seco (PS) de dieta.

\section{5. 4. Análises químicas}

Ao final dos testes (digestibilidade e lixiviação das dietas) e da biometria final dos camarões, as amostras congeladas de fezes e dietas lixiviadas foram liofilizadas (processo de secagem à frio e vácuo) por 24h, para garantir a preservação dos nutrientes, e em seguida, enviadas para análise de PB e $\mathrm{Cr}$ na Central Analítica, do Instituto de Química (IQ), da Universidade de São Paulo (USP).

A PB foi calculada a partir do conteúdo de nitrogênio total multiplicado por 6,25. Segundo o laboratório, o nitrogênio foi determinado por Análise Elementar de $\mathrm{C}$ (carbono), $\mathrm{N}$ (nitrogênio) e $\mathrm{H}$ (hidrogênio). Este método consiste na determinação do percentual dos elementos citados anteriormente, por meio da oxidação completa da amostra de massa conhecida sob oxigênio puro, formando gases de combustão $\left(\mathrm{CO}_{2}, \mathrm{H}_{2} \mathrm{O}, \mathrm{NO}_{2}, \mathrm{~N}_{2} \mathrm{O}_{2}\right)$. Estes gases passam por um tubo contendo cobre metálico, onde são retirados o excesso de oxigênio e reduzidos os óxidos nitrosos em $\mathrm{N}_{2 . .}$ A mistura resultante $\left(\mathrm{CO}_{2}, \mathrm{H}_{2} \mathrm{O}\right.$ e $\left.\mathrm{N}_{2}\right)$ é direcionada para uma coluna cromatográfica, onde os componentes individuais são separados em nitrogênio $\left(\mathrm{N}_{2}\right)$, dióxido de carbono $\left(\mathrm{CO}_{2}\right)$ e água $\left(\mathrm{H}_{2} \mathrm{O}\right)$, e então, detectados através de um Detector de Condutividade Térmica (DCT). 
O Cr foi determinado por ICP-AES (Inductivity Coupled Plasma - Atomic Emission Spectrometer) (Spectro, modelo Gênesis SOP), após oxidação do óxido crômico trivalente $\left(\mathrm{Cr}_{2} \mathrm{O}_{3}\right)$ para sua forma hexavalente e solúvel em água, utilizando ácido nítrico $\left(\mathrm{HNO}_{3}\right)$ e ácido clorídrico $(\mathrm{HCl})$, conforme método 3050B (EPA, 2004), com modificações.

A partir das concentrações de $\mathrm{Cr}$ e $\mathrm{PB}$ na dieta ingerida e nas fezes calculou-se a DAPB dos camarões alimentados com as três dietas (FS, FST e FSM), a partir da equação apresentada por Smith \& Tabrett (2004):

DAPB da dieta $(\%)=\left\{1-\left(\frac{\text { PSCr na dieta imersa }(g) \text { X PSPB nas fezes }(g)}{\text { PSCr nas fezes }(g) \text { X PSPB na dieta imersa }(g)}\right)\right\} \times 100$

Onde, PSCr é a concentração de cromo (Cr) em peso seco (PS), e PSPB é a concentração de proteína bruta (PB) em peso seco (PS). Para as concentrações de PB e Cr nas dietas ingeridas, foram utilizados os resultados médios obtidos nas amostras de dietas lixiviadas.

\section{6. Manutenção dos sistemas com camarões e qualidade da água}

Após a estocagem das pós-larvas de L. vannamei nos tanques e aquários, a manutenção dos sistemas foi feita através da limpeza dos resíduos acumulados no fundo dos tanques e aquários (sifonagem, Figura 8), da lavagem dos filtros de lã e de trocas parciais de água, objetivando manter a qualidade da água dos sistemas. 
As sifonagens ocorreram no primeiro mês de 15 em 15 dias, no segundo e terceiro mês de 20 em 20 dias e, nos meses seguintes, semanalmente até início do teste de digestibilidade, conforme o acúmulo de fezes, sobras de ração e carapaças provenientes da muda. Este ajuste se deu, primeiramente (intervalos de 15 para 20 dias), devido à mudança do tipo de ração, de uma ração granulada para uma ração na forma de pellets (mais compactada) e, conseqüentemente, menos geradora de resíduo. E posteriormente (intervalos de 20 para 7 dias), em função do aumento da quantidade de ração para indivíduos de maior tamanho.

Nos primeiros quatro meses a água proveniente da sifonagem era reutilizada após filtragem física (filtro de lã) e nos meses seguintes esta foi substituída, em função do aumento de material particulado na água, sendo a quantidade de água substituída correspondente à aproximadamente $20 \%$ do volume do sistema de aquários e $2,2 \%$ do sistema de tanques, em cada sifonagem. Durante o teste de digestibilidade foram realizadas sifonagens em dias intercalados, continuando a água sifonada a ser descartada e substituída com nova água salgada.

Os filtros de lã utilizados na filtração física eram lavados com água corrente, finalizando com água destilada e, geralmente, a cada dois dias para o sistema de aquários e a cada quatro dias para o sistema de tanques, ou conforme a necessidade em função do acúmulo de material particulado observado visualmente. Durante o teste de digestibilidade, o filtro foi lavado semanalmente, devido ao maior número de vezes que era feito sifonagem (dia sim, dia não), o que resultava em menor acúmulo de material particulado. 
Quanto às trocas parciais de água durante os sete meses de cultivo dos camarões, no sistema de aquários ocorreram 10 trocas de aproximadamente $23 \%$ do volume total do sistema (cada), e no sistema de tanques três trocas de $10,2 \%$ do volume do sistema (cada), além das substituições efetuadas durante as sifonagens. Tais trocas foram efetuadas quando da elevação da concentração de compostos nitrogenados (ainda que abaixo dos níveis de segurança) e de material particulado na água. Não foram efetuadas trocas de água durante a aclimatação às dietas e teste de digestibilidade.

Com relação ao controle da qualidade da água dos sistemas, durante o cultivo dos animais, inicialmente, monitorou-se salinidade, temperatura, $\mathrm{pH}$, amônia e nitrito diariamente, e, posteriormente, após a constatação da estabilidade dos sistemas, passou-se a um monitoramento semanal do $\mathrm{pH}$, amônia e nitrito. A metodologia utilizada está descrita no item 2.2. Durante a aclimatação às dietas e teste de digestibilidade, o monitoramento da salinidade, temperatura e $\mathrm{pH}$ foi realizado diariamente, enquanto o monitoramento dos compostos nitrogenados (amônia e nitrito) ocorreu, pelo método espectrofotométrico, geralmente, a cada 10 dias. Foram utilizados também, durante todo o período com camarões, kits comercias de análise de amônia, nitrito e nitrato (Tetratest, Alemanha) (Figura 12) e verificou-se a correlação entre os resultados das análises espectrofotométricas e dos kits comerciais para N-AT e N$\mathrm{NO}_{2}$ 


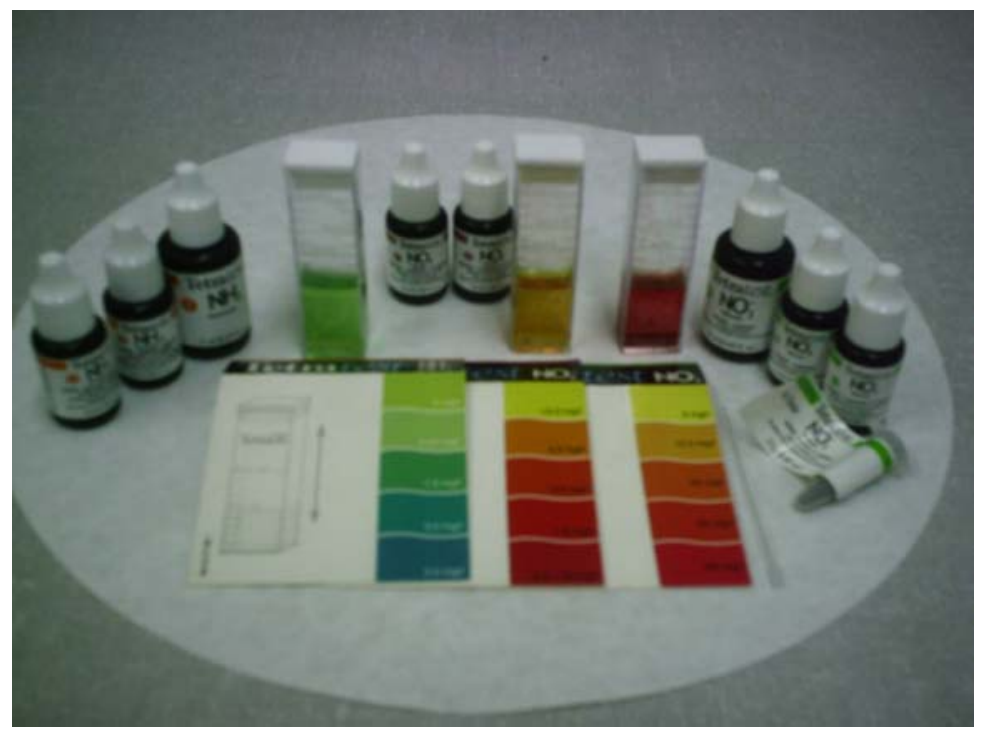

Figura 12. Kits comerciais para análise de amônia, nitrito e nitrato (da esquerda para direita).

A análise de $\mathrm{N}-\mathrm{NO}_{3}$ foi feita pelo Laboratório de Produção Primária e Ecologia do Fitoplâncton (IOUSP), a partir de amostras (duplicata) do $102^{\circ}$ dia (aquários e tanques), utilizando o método de Morris \& Rilley (1963) modificado por Wood et al. (1967) e Grasshoff (1964), descrito em Aminot \& Chaussepied (1983). A concentração de nitrato não foi monitorada regularmente, pois este composto parece ser menos tóxico aos animais (HUGUENIN \& COLT, 1989). A partir da substituição de alimento e aclimatação às dietas foram feitas também análises da concentração de carbonato de cálcio $\left(\mathrm{CaCO}_{3}\right)$ nos sistemas, utilizando kit comercial (Tropic Marin, Alemanha).

As variações de salinidade observadas ocorreram principalmente devido à evaporação diária, que era função da umidade relativa do ar e da temperatura ambiente. Estas variações foram corrigidas com a adição de água destilada aos sistemas, como citado anteriormente. 
Com relação à temperatura, embora o aquecimento da água fosse feito a partir de um aquecedor termostatizado, foram observadas variações que ocorreram principalmente em função da alteração da temperatura ambiente. Desta forma, ajustou-se a temperatura do aquecedor, para mais ou para menos, conforme necessidade.

Após a alocação das pós-larvas nos sistemas, a aeração foi aumentada com auxílio de aeradores (Modelo SR-7500, Aqua One, China), três para os tanques e dois para os aquários, inseridos diretamente nos filtros biológicos. As pedras de aeração foram colocadas tanto na porção de chegada da água, com a finalidade de manter a concentração de oxigênio adequada às bactérias nitrificantes, uma vez que este é um fator limitante ao crescimento das mesmas (SPOTTE, 1979), como na porção de saída da água dos filtros biológicos para os tanques e aquários, a fim de elevar o pH que pode sofrer redução após o aumento de dióxido de carbono $\left(\mathrm{CO}_{2}\right)$ oriundo da respiração bacteriana, além de elevar a concentração de oxigênio dissolvido para a respiração dos camarões.

\section{7. Análises estatísticas}

Foi aplicada análise estatística para comparação das médias de peso entre os diferentes tratamentos (tanques e aquários), das taxas médias de crescimento entre os tratamentos e entre os períodos de pesagem, nas densidades de animais entre os sistemas e nos resultados de DAPB. Os dados foram analisados utilizando o programa SigmaStat, onde para os dados de peso, crescimento e densidade foi aplicado o Teste T de Student (duas médias), quando os dados apresentavam normalidade e homogeneidade de variância. Quando os 
dados não apresentavam estes requisitos (estatística não-paramétrica), aplicou-se o teste da Soma de Rankings de Mann-Whitney. Nos dados de DAPB (três médias) aplicou-se a análise de variância de uma via (one way ANOVA) apenas, pois não houve diferença entre as médias. E na comparação entre os métodos de análise dos compostos nitrogenados (amônia e nitrito) aplicou-se regressão linear com definição do coeficiente de determinação $\left(R^{2}\right)$ em ambos os compostos e $R$ de Pearson para amônia. As diferenças foram consideradas significativas ao nível de $\mathrm{P}<0.05$ (ZAR, 1984), e a elaboração de gráficos foi realizada utilizando o programa Excel (Microsoft Office XP). 


\section{RESULTADOS}

\section{1. Maturação do sistema experimental}

Durante o processo de maturação, $\mathrm{T}^{\circ} \mathrm{C}, \mathrm{S} \%$ e $\mathrm{pH}$ foram monitorados diariamente. Os valores médios e respectivos desvios-padrão, de ambos sistemas, podem ser observados na Tabela 6 .

Tabela 6. Temperatura (T), salinidade ( $\mathrm{S}$ ) e pH em ambos os sistemas durante o período de maturação. Valores expressos em média (desvio padrão).

\begin{tabular}{cccc}
\hline & $\mathbf{T}\left({ }^{\circ} \mathbf{C}\right)$ & $\mathbf{S}(\%)$ & $\mathbf{p H}$ \\
\hline SISTEMA AQUÁRIOS & $28,90(1,44)$ & $35,19(0,54)$ & $8,16(0,09)$ \\
SISTEMA TANQUES & $30,16(1,71)$ & $35,00(0,45)$ & $8,22(0,04)$ \\
\hline
\end{tabular}

Os resultados demonstram que a temperatura apresentou as maiores oscilações nos sistemas, aquários 5\% (coeficiente de variação) e tanques 5,7\%, comparado à salinidade $(1,5 \%$ nos aquários e $1,3 \%$ nos tanques) e ao $\mathrm{pH}(1,1 \%$ nos aquários e $0,5 \%$ nos tanques), mas confrontando os resultando entre os sistemas, todas as variações foram próximas entre si.

Após a primeira adição de amônia (10\% da concentração máxima requerida) foram obtidas amostras diárias durante $72 \mathrm{~h}$ dos sistemas, sem nova adição de $\mathrm{NH}_{4} \mathrm{Cl}$, uma vez que a concentração observada manteve-se maior que a concentração sem a adição de $\mathrm{NH}_{4} \mathrm{Cl}$ (Oh). Estes resultados, que podem ser observados na Figura 13, demonstram a ocorrência de uma gradual redução na concentração de amônia ao longo do tempo e evidenciam que o sistema de tanques apresentou a maior concentração de amônia em 24h $\left(1,93 \mu \mathrm{g} \mathrm{N}-\mathrm{AT} . \mathrm{L}^{-1}\right)$, enquanto o sistema de aquários em $48 \mathrm{~h}\left(1,95 \mu \mathrm{g} \mathrm{N}-\mathrm{AT} \cdot \mathrm{L}^{-1}\right)$. 


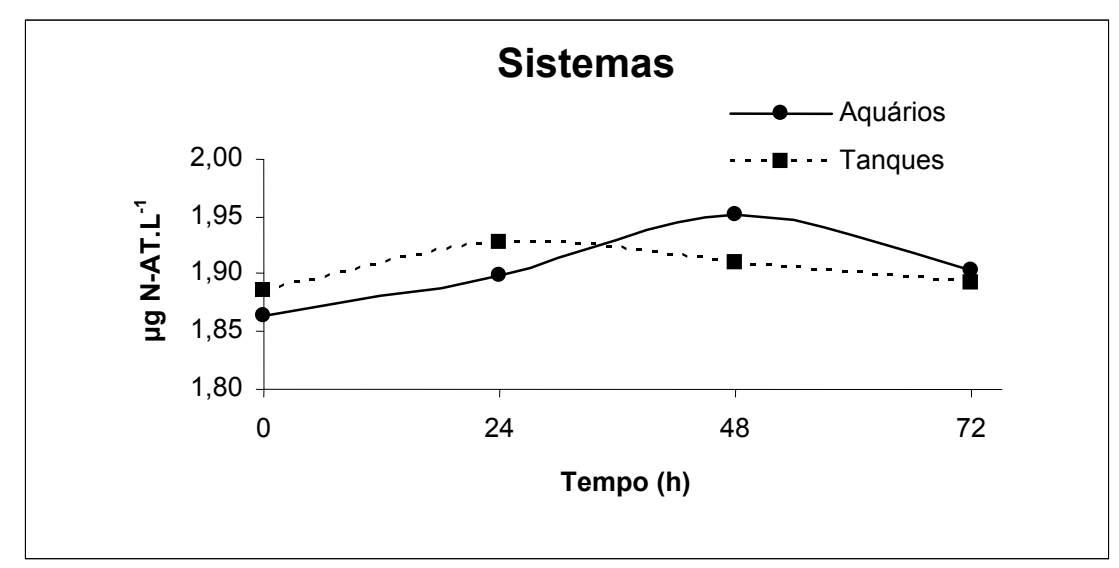

Figura 13. Concentração de nitrogênio amoniacal total (N-AT) nos sistemas de recirculação $72 \mathrm{~h}$ após a primeira adição de cloreto de amônio $\left(\mathrm{NH}_{4} \mathrm{Cl}\right)$, durante o processo de maturação do filtro biológico.

As concentrações médias de N-AT durante todo período de maturação dos sistemas (34 dias) podem ser observadas na Figura 14 e os valores obtidos para as concentrações de nitrito no sistema de aquários estão apresentados na Figura 15. As concentrações de N-AT observadas em ambos os sistemas $(2,00 \mu \mathrm{g}$ N-AT.L ${ }^{-1}$ e 1,96 $\mu \mathrm{g}$ N-AT.L ${ }^{-1}$, nos aquários e tanques, respectivamente) apresentaram-se estáveis e próximas aos valores observados antes do início do processo de maturação $\left(1,86 \mu \mathrm{g} \mathrm{N}-A T \cdot \mathrm{L}^{-1}\right.$ e $1,89 \mu \mathrm{g} \mathrm{N}-\mathrm{AT} . \mathrm{L}^{-1}$, nos aquários e tanques, respectivamente).No entanto, no sistema de aquários o nitrito apresentou picos de concentração em intervalos de 12 e 10 dias, com concentrações entre 3,23 $\mu \mathrm{g} \mathrm{N}-\mathrm{NO}_{2} \cdot \mathrm{L}^{-1}$ e $3,53 \mu \mathrm{g} \mathrm{N}-\mathrm{NO}_{2} \cdot \mathrm{L}^{-1}$, seguidos da redução do composto. $\mathrm{O}$ sistema de tanques não apresentou concentração detectável pelo método de análise (mínimo de $0.01 \mu \mathrm{M} \mathrm{N}-\mathrm{NO}_{2}$ ). 


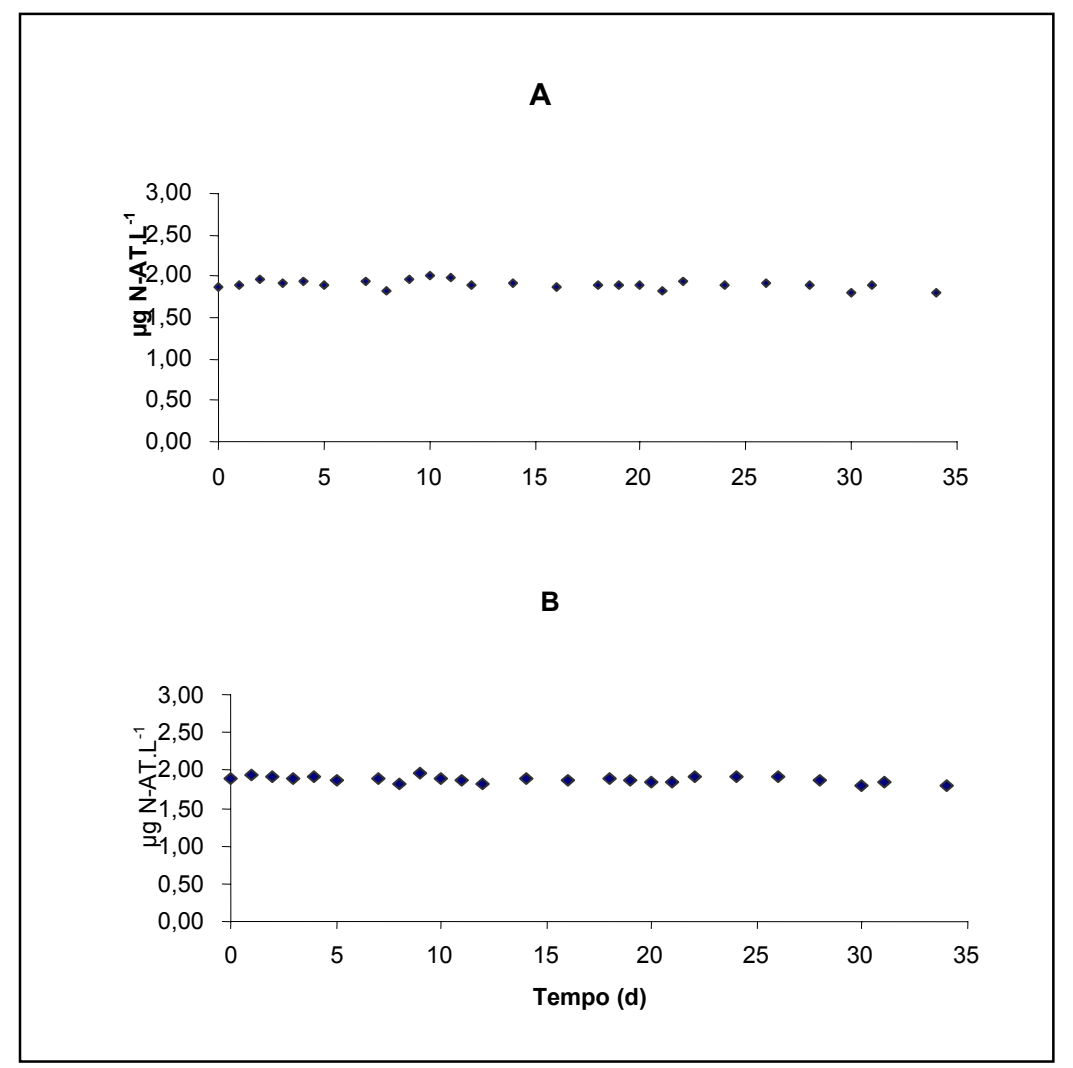

Figura 14. Concentração de nitrogênio amoniacal total (N-AT) nos sistemas de recirculação durante o processo de maturação do filtro biológico com cloreto de amônio $\left(\mathrm{NH}_{4} \mathrm{Cl}\right)$. A: sistema de aquários e $\mathrm{B}$ : sistema de tanques.

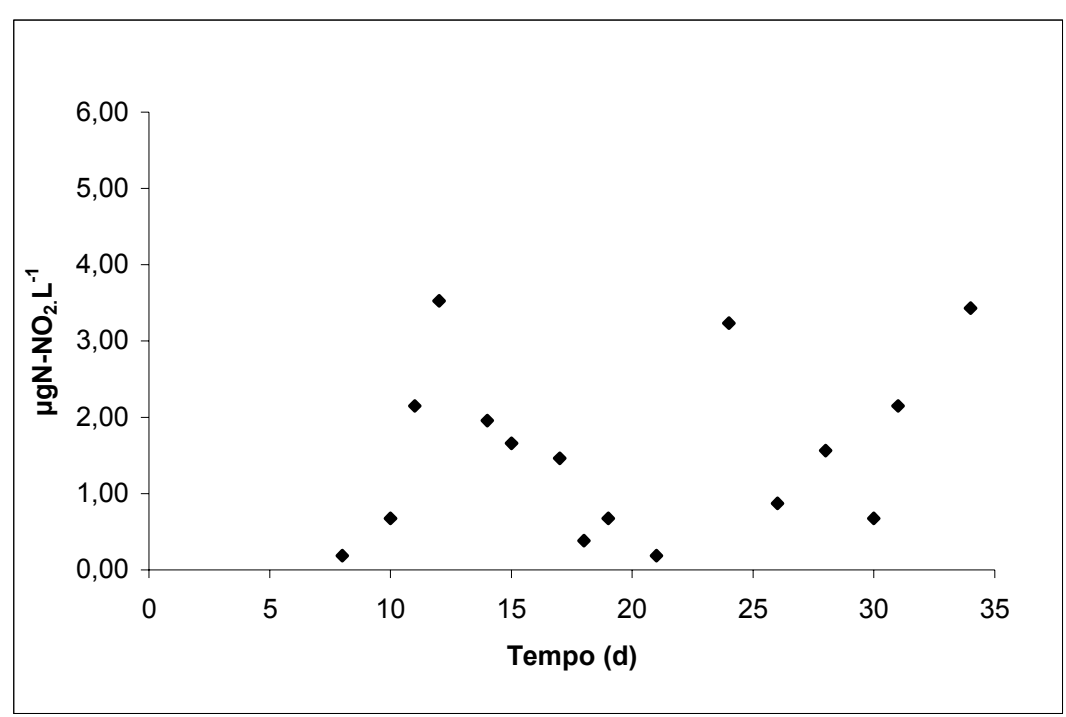

Figura 15. Concentração de nitrito $\left(\mathrm{N}-\mathrm{NO}_{2}\right)$ no sistema de aquários durante o processo de maturação do filtro biológico com cloreto de amônio $\left(\mathrm{NH}_{4} \mathrm{Cl}\right)$. 


\section{2. Cultivo dos organismos experimentais}

O cultivo dos camarões com ração comercial teve duração de 207 dias. Neste período, os organismos foram pesados seis vezes com intervalos aproximados de 30 dias. Os valores observados constam na Tabela 7, nos quais foi aplicada análise estatística para comparação das médias de peso entre os diferentes tratamentos (tanques e aquários) e das taxas de crescimento, entre os tratamentos e entre os períodos de pesagem.

A análise estatística mostrou que os pesos dos camarões foram diferentes entre os sistemas de cultivo na maioria das idades pós-larvais, com exceção de PL139. Embora as taxas de crescimento observadas não terem sido diferentes entre os sistemas para todas as idades pós-larvais. A partir de PL70 as taxas de crescimento apresentadas pelos sistemas alternaram-se entre diferente e igual a cada período.

Com indivíduos menores que $3 \mathrm{~g}$, a taxa de crescimento foi 2,17 vezes maior no sistema de aquários do que nos tanques, e com indivíduos maiores que $6 \mathrm{~g}$ o sistema de tanques apresentou taxas de crescimento 1,62 e 1,26 vezes maiores que as taxas apresentadas pelos aquários. No entanto, os indivíduos menores que $3 \mathrm{~g}$ sofreram seleção em PL70, durante a realocação dos animais por tamanho (a fim de reduzir o canibalismo), permanecendo os maiores e menores no sistema de aquários, e médios nos tanques. 
Tabela 7. Peso úmido e taxa de crescimento individual de Litopenaeus vannamei em função do sistema de cultivo: aquários $(A)$ e tanques $(T)$, durante o cultivo com ração comercial. Resultados expressos como média (desvio padrão) [n].

\begin{tabular}{|c|c|c|c|c|}
\hline \multirow[t]{2}{*}{$\begin{array}{l}\text { Idade pós- } \\
\text { larval (dias) }\end{array}$} & \multicolumn{2}{|c|}{ Peso (g) } & \multicolumn{2}{|c|}{$\begin{array}{c}\text { Taxa de crescimento } \\
\text { (g/semana })^{1}\end{array}$} \\
\hline & A & $T$ & A & $T$ \\
\hline \multirow[t]{2}{*}{20} & \multicolumn{2}{|c|}{$0,002(0,000)[40]^{2}$} & & \\
\hline & & & 0,021 & 0,048 \\
\hline \multirow[t]{2}{*}{70} & $0,146(0,144)[16]^{a}$ & $0,336(0,419)[43]^{\mathrm{b}}$ & & \\
\hline & & & $0,605(0,285)^{a}$ & $0,279(0,027)^{b}$ \\
\hline \multirow[t]{2}{*}{106} & $2,914(1,444)[37]^{a}$ & $1,770(0,817)[38]^{\mathrm{b}}$ & & \\
\hline & & & $0,793(0,200)^{c, d}$ & $0,985(0,143)^{c, e}$ \\
\hline \multirow[t]{2}{*}{139} & $6,270(1,961)[29]^{a}$ & $6,392(1,786)[31]^{a}$ & & \\
\hline & & & $0,669(0,346)^{d}$ & $1,085(0,157)^{\mathrm{e}}$ \\
\hline \multirow[t]{2}{*}{170} & $9,709(2,143)[28]^{a}$ & $11,217(1,772)[26]^{\mathrm{b}}$ & & \\
\hline & & & $0,786(0,356)^{d, g}$ & $0,990(0,148)^{\mathrm{e}, \mathrm{g}}$ \\
\hline 217 & $15,124(2,789)[17]^{a}$ & $17,855(2,073)[26]^{b}$ & & \\
\hline
\end{tabular}

A partir de PL106, a comparação entre as taxas de crescimento para um mesmo sistema não apresentou diferenças significativas tanto nos aquários como nos tanques. Houve diferença apenas entre os períodos de PL70-PL106 para PL106-PL139 nos dois tratamentos. Nos tanques, a taxa de crescimento aumentou até a idade pós-larval de 170 dias, reduzindo-se em seguida, enquanto nos aquários, a taxa aumentou até a PL139, reduzindo entre PL139 e PL170, mas voltando a aumentar entre PL170 e 217.

Com relação às densidades (indivíduos/área) em que os animais foram mantidos nos sistemas de cultivo durante os 207 dias, a Tabela 8 apresenta os valores observados em cada período e a comparação das densidades médias entre os sistemas. Sendo observadas diferenças significativas apenas entre PL70 
e PL217. É possível notar que as densidades foram elevadas durante o início do cultivo, prática que teve por objetivo garantir a sobrevivência de animais para o teste de digestibilidade. A redução nas densidades foi função da elevada mortalidade apresentada nos sistemas (aquários: até PL106 e tanques: até PL70), como é possível observar na Tabela 9.

Tabela 8. Densidades dos camarões Litopenaeus vannamei nos diferentes sistemas: aquários $(A)$ e tanques $(T)$ durante o cultivo com ração comercial. Resultados expressos como média (desvio padrão).

\begin{tabular}{ccc}
\hline $\begin{array}{c}\text { Idade pós-larval } \\
\text { (dias) }\end{array}$ & \multicolumn{2}{c}{ Densidades (indivíduos $/ \mathbf{m}^{2}$ ) } \\
\hline 20 & $\mathbf{A}$ & $\mathbf{T}$ \\
\cline { 2 - 3 } 70 & 400 & $525 / 1350^{*}$ \\
106 & $28,3^{\mathrm{a}}(3,13)$ & $26,2^{\mathrm{b}}(14,4) / 78^{*}$ \\
139 & $25,9^{\mathrm{a}}(10,9)$ & $33,9^{\mathrm{a}}(7,44)$ \\
170 & $21,9^{\mathrm{a}}(5,59)$ & $26,8^{\mathrm{a}}(2,06)$ \\
217 & $13,3^{\mathrm{a}}(3,13)$ & $23,2^{\mathrm{a}}(2,06)$ \\
& $23,2^{\mathrm{b}}(2,06)$ \\
\hline
\end{tabular}

*Valores do tanque-estoque (não contabilizados na média). Valores com diferentes letras, entre colunas, são significativamente diferentes $(P<0,05)$.

Tabela 9. Taxa de sobrevivência de Litopenaeus vannamei em função do sistema de cultivo: aquários $(A)$ e tanques $(T)$ durante o período de cultivo com ração comercial $^{*}$.

\begin{tabular}{ccc}
\hline $\begin{array}{c}\text { Idade pós-larval } \\
\text { (dias) }\end{array}$ & \multicolumn{2}{c}{ Sobrevivência (\%) } \\
\hline $20-70$ & A & T \\
\cline { 2 - 3 } $70-106$ & 46,8 & 6,59 \\
$106-139$ & 83,8 & 87,0 \\
$139-170$ & 100 & 84,2 \\
$170-217$ & 100 & 90,0 \\
\end{tabular}

* Considerou-se o total de indivíduos presentes em cada sistema. Foram excluídos os indivíduos que saltaram dos sistemas e os retirados por apresentarem sintomas patogênicos. 
Nos tanques, a sobrevivência foi maior que $80 \%$ na maioria das idades pós-larvais, exceto no período inicial de PL20 a PL70. Neste período, a diferença entre as densidades do tanque-estoque e os outros tanques não representou mortalidades muito diferenciadas, $94,18 \%$ e $92,74 \%$, respectivamente. Em comparação com o sistema de aquários, a sobrevivência nos tanques foi menor nos períodos de PL20-PL70 e PL139-PL170, embora em PL20-PL70 a sobrevivência tenha sido muito próxima à do sistema de aquários, e igual para o período de PL170-PL217 (100\%). No sistema de aquários, a taxa de sobrevivência foi menor que 47\% para os indivíduos mais jovens (PL20-PL70 e PL70-PL106), acima de $80 \%$ para o período de PL106-PL139 e de $100 \%$ a partir de PL139.

Com relação à alimentação, esta foi ajustada visualmente conforme a demanda, visando sempre pequena sobra de alimento. Assim, a partir da quantidade de ração oferecida (g) e da biomassa dos animais (g) foi possível estabelecer a curva de tendência da ração oferecida em função da biomassa (Figura 16). Nesta curva, é possível visualizar que camarões mais jovens consomem mais alimento que camarões adultos em relação a sua biomassa corporal. Os dados demonstraram também que os camarões do sistema de tanques, por serem maiores durante todo o trabalho (com exceção ao período pós PL70, no qual ocorreu a seleção dos animais por tamanho), sempre apresentaram menor consumo em relação a sua biomassa. Ao final do cultivo, os animais que se encontravam nos aquários consumiam em ração, cerca de $6,7 \%$ de sua biomassa corporal, e nos tanques, $5,2 \%$. Ao final do teste de digestibilidade, esses valores alcançaram 3,6\% e 2,2\%, nos aquários e tanques, respectivamente. 


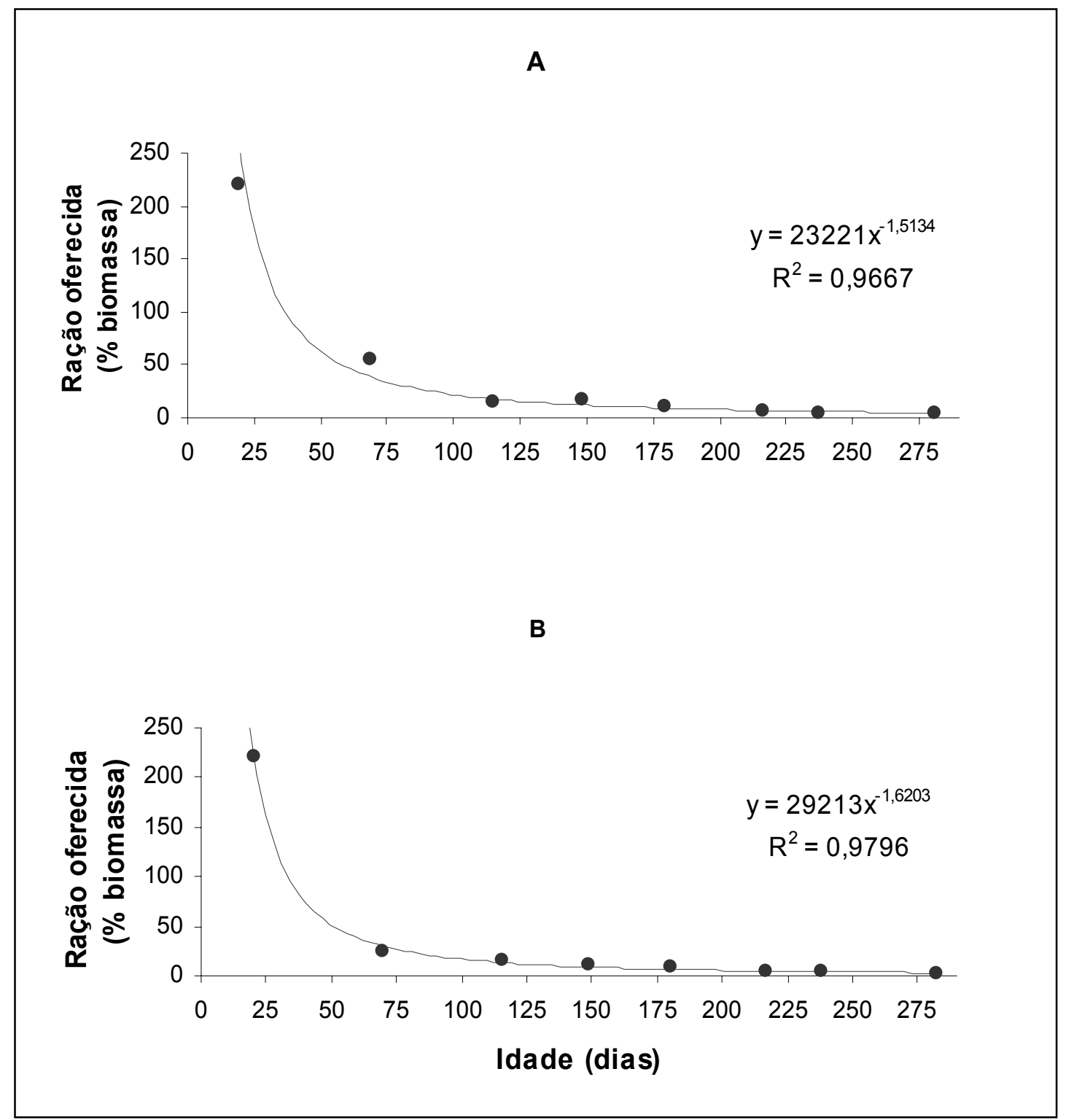

Figura 16. Ração oferecida aos camarões em porcentagem de biomassa (peso médio ração $(\mathrm{g}) /$ peso médio individual camarão $(\mathrm{g})$ x 100) em relação à idade pós larval: sistemas de aquários $(A)$ e sistemas de tanques (B).

Foi possível verificar também o ganho de peso e a taxa de crescimento durante todo o período de cultivo dos camarões com ração comercial, em ambos os sistemas, após $3 \mathrm{~g}$ de peso úmido individual (Tabela 10). 
Tabela 10. Médias de peso úmido inicial (PL106), final (PL217), ganho de peso e taxa de crescimento de Litopenaeus vannamei após $3 \mathrm{~g}$, durante o período de alimentação com ração comercial nos sistemas de aquários e tanques. Resultados expressos como média (g), desvio padrão (DP) e coeficiente de variação (CV\%).

\begin{tabular}{|c|c|c|c|c|}
\hline & Peso inicial (g) & Peso final (g) & Ganho peso (g) & $\begin{array}{c}\text { Taxa de } \\
\text { crescimento } \\
\text { (g/semana) }\end{array}$ \\
\hline \multicolumn{5}{|c|}{ Aquários } \\
\hline Média & $2,91^{a}$ & $15,12^{a}$ & $11,88^{a}$ & $0,75^{a}$ \\
\hline DP & 1,44 & 2,80 & 3,60 & 0,23 \\
\hline$C V(\%)$ & 49,56 & 18,50 & 30,30 & 30,30 \\
\hline \multicolumn{5}{|c|}{ Tanques } \\
\hline Média & $1,77^{b}$ & $17,86^{b}$ & $16,12^{b}$ & $1,02^{b}$ \\
\hline DP & 0,82 & 2,07 & 0,66 & 0,04 \\
\hline$C V(\%)$ & 46,14 & 11,61 & 4,12 & 4,12 \\
\hline
\end{tabular}

Valores com diferentes letras, entre linhas, são significativamente diferentes $(P<0,05)$.

Nestes resultados, é possível observar que os camarões cultivados nos tanques apresentaram valores significativamente maiores de peso médio final, ganho de peso médio no período e taxas de crescimento, além disso, os coeficientes de variação (CV) apresentados por estas médias (46,14\%, 11,61\% e $4,12 \%$, respectivamente) foram menores que os apresentados pelo sistema de aquários $(49,56 \%, 18,50 \%$ e $30,30 \%$, respectivamente). Apenas o peso inicial dos camarões foi significativamente menor nos tanques. Para ganho de peso e taxa de crescimento o cálculo da média do sistema de tanques utilizou pesos médios por tanque, ao invés de pesos absolutos como os empregados no cálculo destas médias nos sistema de aquários, por isto, não foi possível o cálculo de desviopadrão e coeficientes de variação.. 


\section{3. Lixiviação das dietas}

A lixiviação e as concentrações de PB e Cr apresentadas pelas dietas antes e após imersão, por 30 min., em água salgada são apresentadas na Tabela 11. Nos resultados é possível observar que não houve diferenças significativas nas concentrações de PB entre antes e após imersão em todas as dietas, apesar do mesmo não ter ocorrido para as concentrações de $\mathrm{Cr}$, que foram significativamente diferentes em todas as dietas. A taxa de lixiviação da PB entre as dietas variou de $2,9 \%$ a $9,6 \%$ e para o $\mathrm{Cr}$ de $22,8 \%$ a $31,6 \%$, sendo, am ambos os compostos analisados, maior para FST, seguida de FSM e FS. Proporcionalmente, a lixiviação do $\mathrm{Cr}$ em relação à $\mathrm{PB}$, foi maior para $\mathrm{FS}(7,8$ vezes) e igual entre FST e FSM (3,3 vezes).

Tabela 11. Concentração média (\%) (matéria seca), desvio padrão e coeficiente de variação (\%) e lixiviação (\%) de proteína bruta (PB) e óxido crômico $(\mathrm{Cr})$ nas dietas experimentais (FS, FST e FSM) após imersão em água salgada $(n=2$, exceto $\mathrm{Cr} 0 \mathrm{~min}$, onde $n=3$ )

\begin{tabular}{|c|c|c|c|c|c|c|}
\hline \multirow{2}{*}{ Imersão (min) } & \multicolumn{2}{|l|}{ FS } & \multicolumn{2}{|l|}{ FST } & \multicolumn{2}{|l|}{ FSM } \\
\hline & PB & $\mathrm{Cr}$ & PB & $\mathrm{Cr}$ & PB & $\mathrm{Cr}$ \\
\hline 0 & $\begin{array}{c}35,05 \\
(3,43)^{\text {a }}\end{array}$ & $\begin{array}{c}0,32 \\
(0,06)^{a}\end{array}$ & $\begin{array}{c}35,28 \\
(1,07)^{a}\end{array}$ & $\begin{array}{c}0,32 \\
(0,06)^{a}\end{array}$ & $\begin{array}{c}34,38 \\
(1,10)^{a}\end{array}$ & $\begin{array}{c}0,32 \\
(0,07)^{a}\end{array}$ \\
\hline CV (\%) & 10,00 & 18,75 & 3,00 & 18,75 & 3,20 & 21,88 \\
\hline 30 & $\begin{array}{c}34,03 \\
(5,74)^{a}\end{array}$ & $\begin{array}{c}0,24 \\
(0,04)^{b}\end{array}$ & $\begin{array}{c}31,91 \\
(4,86)^{a}\end{array}$ & $\begin{array}{c}0,22 \\
(0,14)^{b}\end{array}$ & $\begin{array}{c}31,62 \\
(33,59)^{a}\end{array}$ & $\begin{array}{c}0,24 \\
(0,09)^{b}\end{array}$ \\
\hline CV (\%) & 16,88 & 16,67 & 15,23 & 63,64 & 106,23 & 37,50 \\
\hline Lixiviação (\%) & 2,915 & 22,844 & 9,575 & 31,594 & 8,023 & 26,484 \\
\hline
\end{tabular}

Valores com diferentes letras, por colunas, são significativamente diferentes $(P<0,05)$. 


\section{4. Teste de digestibilidade protéica}

Os resultados observados de DAPB para os sistemas constam na Tabela 12. Dois camarões aclimatados com a dieta FS saltaram dos aquários e morreram, sendo que um morreu durante a aclimatação às dietas e o outro, participou de aproximadamente $2 / 3$ do teste (21 dias), portanto, considerado apenas para o cálculo da DAPB (proporcionalmente ao período em teste). Assim, a sobrevivência nos sistemas durante aclimatação às dietas e teste de digestibilidade foi de $100 \%$, uma vez que a mortalidade por saltos para fora das unidades experimentais não são consideradas, pois não é efeito dos tratamentos alimentares. Com relação à distribuição $\mathrm{Cr}_{2} \mathrm{O}_{3}$ nas fezes, foi verificado, visualmente, a não homogeneidade da cor verde, o que indica possível distribuição heterogênea do marcador nas fezes, portanto, necessidade de coleta total das fezes.

No sistema de aquários, as médias de DAPB não mostraram diferenças significativas entre as dietas (FS, FST e FSM), mas a menor DAPB foi observada na dieta FST, aumentando em FSM e FS. A maior diferença nos valores de DAPB entre as dietas foi verificada entre FST e FS $(2,1 \%)$ e a menor entre FS e FSM $(0,7 \%)$. Nos tanques, apesar não ter sido possível a realização de testes estatísticos nas amostras devido à ausência de réplicas, é possível verificar uma tendência de aumento da DAPB de FS para FST, e seguindo para FSM. A maior diferença foi entre FS e FSM $(3,7 \%)$ e a menor entre FS e FST $(1,1 \%)$.

É possível perceber nos dados que a dieta FS apresentou, nos aquários, a maior DAPB, enquanto nos tanques obteve a menor. A dieta FST apresentou a menor DAPB nos aquários e a intermediária nos tanques, enquanto a FSM demonstrou a DAPB mais elevada nos tanques e foi a intermediária nos aquários. 
Com relação ao intervalo de DAPB apresentado pelos sistemas, nos tanques este foi mais elevado, oscilando entre $80,3 \%$ e $84,0 \%$, enquanto nos aquários entre $78,8 \%$ e $80,9 \%$.

Tabela 12. Digestibilidade aparente de proteína bruta (DAPB) (\%) para as dietas experimentais FS, FST e FSM, utilizando o método do marcador inerte (óxido crômico). Resultados expressos em média (desvio padrão) [n].

\begin{tabular}{cccc}
\hline \multirow{2}{*}{ SISTEMA } & \multicolumn{3}{c}{ DAPB } \\
\cline { 2 - 4 } & FS & FST & FSM \\
\hline Aquários $^{\text {Tanques }}{ }^{2}$ & $80,9(3,32)[4]^{1, a}$ & $78,8(6,40)[5]^{\mathrm{a}}$ & $80,2(6,56)[5]^{\mathrm{a}}$ \\
Tay $^{\mathrm{a}}$ & 80,3 & 82,1 & 84,0 \\
\hline
\end{tabular}

${ }^{1}$ Nesta média foi utilizado o indivíduo que morreu na metade do experimento.

Valores com letras iguais, entre colunas, não são significativamente diferentes $(P>0,05)$.

As médias de peso inicial e final, ganho de peso e taxa de crescimento nos sistemas durante a alimentação com as dietas experimentais podem ser observadas na Tabela 13. Os resultados não apresentaram diferenças significativas em nenhum parâmetro entre as três dietas testadas (FS, FST e FSM) no sistema de aquários. No entanto, é possível perceber que as médias de ganho de peso e taxa de crescimento foram maiores para FST, seguida de FS, e por último, FSM, ou seja, a dieta que apresentou o melhor desempenho (FST) foi a que obteve menor DAPB, e a dieta com maior DAPB (FS) foi a que obteve desempenho intermediário no ganho de peso e taxa de crescimento. Com relação ao peso médio final, apesar das médias não serem significativamente diferentes entre as dietas, a maior média foi observada com a dieta FSM, embora o peso inicial médio dos camarões, nesta dieta, também tenha sido maior em relação às demais dietas. As taxas de crescimento foram muito próximas entre si $(0,19$ à 0,26g/semana). Nota-se também o elevado CV (\%) apresentado pelos parâmetros, que variou de $15,3 \%$ à $21,4 \%$ para peso inicial, de $11,8 \%$ à $21,3 \%$ no 
peso final, e $50,9 \%$ à $112,6 \%$ no ganho de peso e taxa de crescimento, sendo que os maiores coeficientes foram observados na dieta FST, com exceção do peso inicial, onde o maior CV foi observado para a dieta FSM, enquanto os menores CVs foram apresentados pela dieta FS.

No sistema de tanques também não houve diferenças significativas comparando os pesos iniciais e finais entre as dietas. No entanto, o maior ganho de peso e taxa de crescimento ocorreu na dieta FSM, seguida de FS e, posteriormente, de FST, sendo que a dieta FST apresentou taxa de crescimento aproximadamente duas vezes menor que FS e FSM. Esta observação demonstra que, neste sistema, a dieta que apresentou maior DAPB (FSM) proporcionou também o melhor desempenho aos camarões, considerando ganho de peso e taxa de crescimento. Com relação à média de peso final, a maior média foi observada nos camarões alimentados com a dieta FS, no entanto, como observado nos aquários, o peso inicial destes camarões era também maior que dos alimentados com as demais dietas. Considerando os CVs apresentados nos tanques, estes oscilaram entre $6,5 \%$ e $19,1 \%$ para peso inicial e de $6,4 \%$ à $20,1 \%$ para peso final, sendo os menores valores observados com a dieta FSM e maiores na dieta FST.

Comparando os sistemas de tanques e aquários, verifica-se que os parâmetros observados (peso inicial, final, ganho de peso e taxa de crescimento) apresentaram médias maiores nos tanques e, para peso inicial e final, coeficientes de variação maiores nos aquários, com exceção do CV apresentado pelo peso inicial na dieta FST (aquários < tanques), embora muito semelhantes (19,0 e $19,1 \%)$. 
Tabela 13. Peso úmido inicial (PL238), final (PL282), ganho de peso e taxa de crescimento de Litopenaeus vannamei durante o período de alimentação com dietas experimentais (FS, FST e FSM). Resultados expressos como peso médio em gramas (g) [n aquários/tanques], desvio padrão (DP) e coeficiente de variação em porcentagem (CV\%).

\begin{tabular}{lcccc}
\hline & Peso inicial (g) & Peso final $\mathbf{( g )}$ & Ganho peso $\mathbf{( g )}$ & $\begin{array}{c}\text { Taxa de } \\
\text { crescimento } \\
\text { (g/semana) }\end{array}$ \\
\hline Aquários & & & & \\
\hline Dieta FS & $15,28^{\mathrm{a}}$ & $16,57^{\mathrm{a}}$ & $1,29^{\mathrm{a}}$ & $0,20^{\mathrm{a}}$ \\
Média & 2,34 & 1,96 & 0,66 & 0,10 \\
DP & 15,34 & 11,80 & 50,89 & 50,89 \\
CV(\%) & & & & \\
Dieta FST & $16,34^{\mathrm{a}}$ & $17,98^{\mathrm{a}}$ & $1,64^{\mathrm{a}}$ & $0,26^{\mathrm{a}}$ \\
Média & 3,11 & 3,83 & 1,85 & 0,29 \\
DP & 19,04 & 21,32 & 112,57 & 112,57 \\
CV(\%) & & & $0,19^{\mathrm{a}}$ \\
Dieta FSM & $17,29^{\mathrm{a}}$ & $18,48^{\mathrm{a}}$ & $1,19^{\mathrm{a}}$ & 0,15 \\
Média & 3,70 & 3,43 & 0,85 & 71,81 \\
DP & 21,43 & 18,55 & 71,81 & \\
CV(\%) & & & & \\
& & &
\end{tabular}

\section{Tanques}

\section{Dieta FS}

Média

$22,13[4]^{a}$

$25,92[4]^{\mathrm{a}}$

3,79

0,60

DP

1,45

2,63

CV(\%)

6,55

10,13

Dieta FST

Média

DP

CV(\%)

Dieta FSM

$\begin{array}{lc}\text { Média } & 20,00[4]^{a} \\ \text { DP } & 1,48 \\ \text { CV(\%) } & 7,38\end{array}$

$$
3,79
$$

$$
\begin{gathered}
21,84[4]^{a} \\
4,39 \\
20,12
\end{gathered}
$$

1,98

0,32

$$
\begin{gathered}
23,98[4]^{\mathrm{b}} \\
1,53 \\
6,37
\end{gathered}
$$

Valores com letras iguais, entre linhas por sistema, para peso inicial e final, e para o sistema de aquários considerando também ganho de peso e taxa de crescimento, não são significativamente diferentes $(P>0,05)$. 


\section{6. Manutenção dos sistemas e qualidade da água}

Os resultados de temperatura, salinidade e $\mathrm{pH}$, monitorados após a chegada dos camarões, podem ser observados na Tabela 14. É possível constatar que no período com animais as oscilações de temperatura e salinidade nos sistemas foram próximas entre si, como também foi observado durante o período de maturação dos sistemas (item 3.1.). A temperatura variou de 3,6\% (aquários) à $3,9 \%$ (tanques), o $\mathrm{pH}$ de 2,9\% (aquários) à 2,8\% (tanques). No entanto, a salinidade apresentou uma maior diferença entre os sistemas, 3,2\% (aquários) e $1,6 \%$ (tanques).

Tabela 14. Temperatura (T), salinidade (S) e $\mathrm{pH}$ em ambos os sistemas durante o período de cultivo dos camarões, aclimatação às dietas e teste de digestibilidade. Valores expressos em média (desvio padrão).

\begin{tabular}{cccc}
\hline & $\mathbf{T}\left({ }^{\circ} \mathbf{C}\right)$ & $\mathbf{S}(\%)$ & $\mathbf{p H}$ \\
\hline SISTEMA AQUÁRIOS & $30,08(1,10)$ & $34,87(1,13)$ & $7,90(0,23)$ \\
SISTEMA TANQUES & $30,18(1,17)$ & $35,19(0,57)$ & $7,92(0,22)$ \\
\hline
\end{tabular}

Neste período, as maiores oscilações (CV), embora menores que durante a maturação, também foram verificadas na temperatura, e as menores para a salinidade nos tanques, seguida do $\mathrm{pH}$, mas comparando as oscilações deste período com a fase de maturação, a salinidade e o $\mathrm{pH}$ apresentaram oscilações maiores.

$\mathrm{O}$ resultado do monitoramento dos compostos nitrogenados (N-AT e N$\mathrm{NO}_{2}$ ) durante todo o período após a alocação das pós-larvas aos sistemas esta 
apresentado na Figura 17. Os valores mais elevados de N-AT foram alcançados durante o cultivo dos animais com ração comercial, tanto nos aquários $(0,009$ e $\left.0,008 \mathrm{mg} \cdot \mathrm{L}^{-1}\right)$, como nos tanques $\left(0,008 \mathrm{mg} \cdot \mathrm{L}^{-1}\right)$, que representam cada $0,47 \mu \mathrm{g}$ de $\mathrm{N}-\mathrm{NH}_{3}$, nas respectivas salinidades e temperaturas observadas nas coletas (BAUMGARTEN et al., 1996). Para o $\mathrm{N}^{-N_{2}}$, as concentrações máximas observadas foram 0,15 e $0,10 \mathrm{mg} \cdot \mathrm{L}^{-1}$ (aquários) e, $0,10 \mathrm{mg} \cdot \mathrm{L}^{-1}$ (tanques), também verificadas durante o cultivo para crescimento dos animais. As concentrações de carbonato de cálcio durante a aclimatação às dietas e teste de digestibilidade podem ser verificadas na Figura 18.

Após o início da substituição da alimentação (dia 210) e, em seguida, durante o teste de digestibilidade, as concentrações de ambos os compostos apresentaram-se declinantes. As análises de nitrato com amostras $(n=2)$ do $102^{\circ}$ dia (de ambos os sistemas) resultaram em 1,16 $\mathrm{mg} \mathrm{N}-\mathrm{NO}_{3} \cdot \mathrm{L}^{-1}$ (aquários) e 1,12 mg N-NO $3 \cdot \mathrm{L}^{-1}$ (tanques).

A comparação entre os resultados (amônia, nitrito e nitrato) apresentados pelas análises espectrofotométricas e pelos kits comercias demonstrou que quando os métodos resultavam em valores muito próximos a zero, os kits comerciais não detectavam os compostos. No entanto, quando pequenas elevações nas concentrações ocorriam, os kits apresentavam valores muito acima dos determinados espectrofotometricamente, em torno de 28 à 42 vezes maior para amônia, de 30 à 15 vezes para nitrito e 2,5 vezes para nitrato. Os coeficientes de determinação $\left(R^{2}\right)$ apresentados entre as análises foram de 0,374 para amônia e 0,000 para nitrito, enquanto o coeficiente de correlação $(R$ de 
Pearson) foi de 0,609 positivo $(p<0,05)$ para amônia, não havendo correlação para nitrito. A correlação não foi testada para o nitrato pois foram analisadas apenas duas amostras.

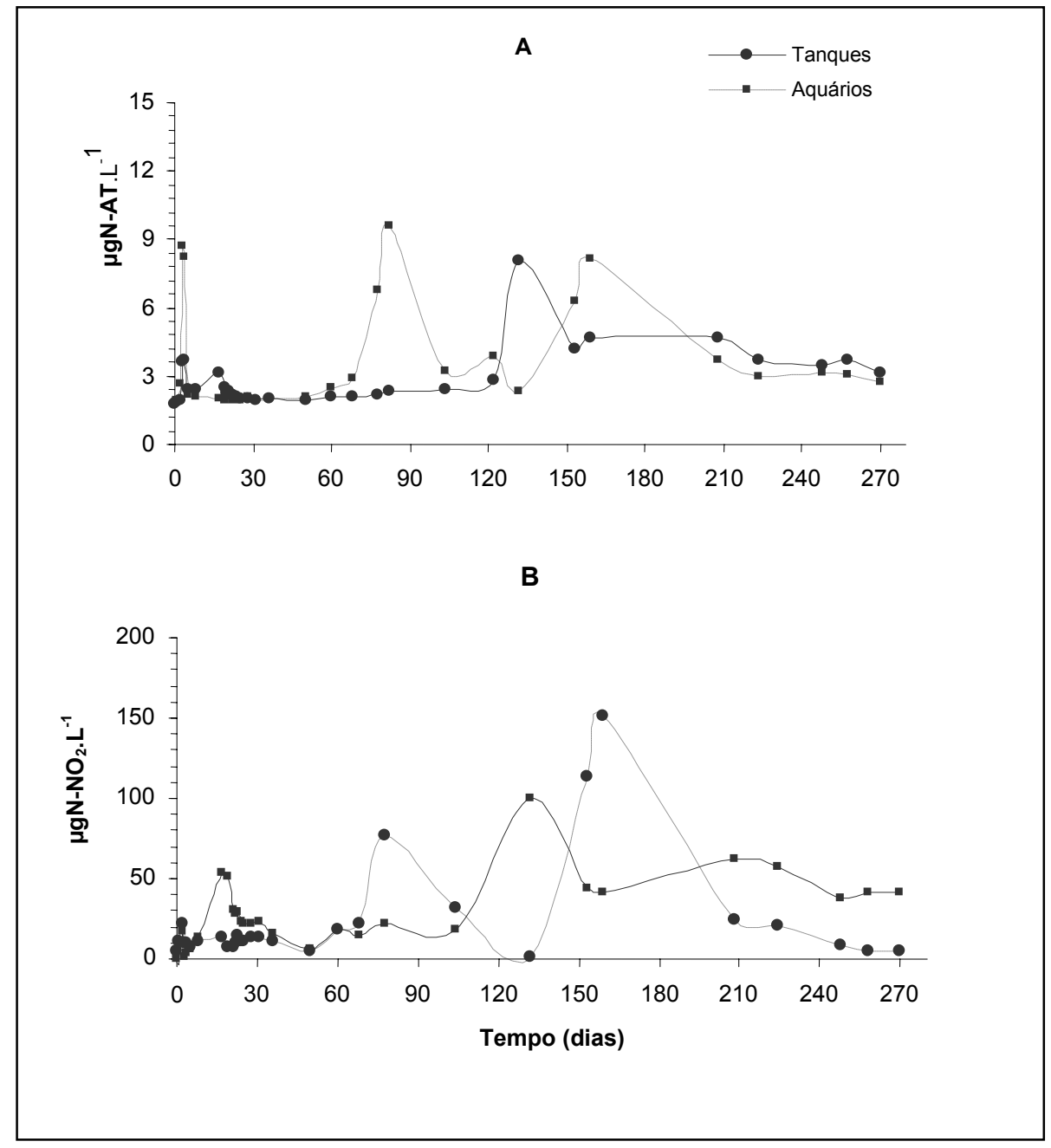

Figura 17. Valores observados de nitrogênio amoniacal total (N-AT) e nitrito (N$\mathrm{NO}_{2}$ ) nos sistemas de recirculação, aquários $(\mathrm{A})$ e tanques $(\mathrm{B})$, durante todo o período com camarões: cultivo para crescimento (0 à 207 dias), aclimatação às dietas experimentais (210 à 235 dias) e teste de digestibilidade (236 à 272 dias). Resultados expressos como médias $(n=3)$. 


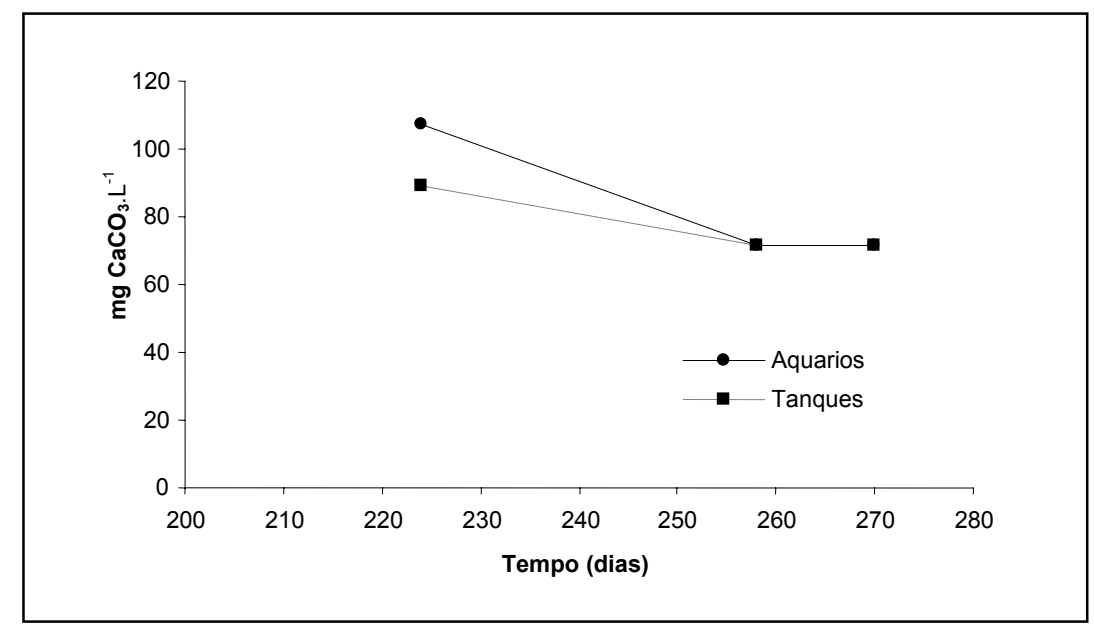

Figura 18. Concentração de carbonato de cálcio $\left(\mathrm{CaCO}_{3}\right)$ durante a aclimatação às dietas experimentais (210 à 235 dias) e teste de digestibilidade (236 à 272 dias) nos sistemas de recirculação (aquários e tanques). Resultados expressos em $\mathrm{mg} / \mathrm{L}$. 


\section{DISCUSSÃO}

\section{1. Maturação do sistema experimental}

A duração do período de maturação até 120\% (28 dias) da concentração máxima requerida de amônia $\left(0,007 \mathrm{mg} \mathrm{N}-\mathrm{AT} \cdot \mathrm{L}^{-1} \cdot \mathrm{dia}^{-1}\right.$ e $\left.0,002 \mathrm{mg} \mathrm{N}-\mathrm{AT} \cdot \mathrm{L}^{-1} \cdot \mathrm{dia}^{-1}\right)$ concorda com o apresentado por Kamimura (2002) (26 dias), embora as concentrações máximas alcançadas pelo referido autor tenham sido diferentes (0,835 mg N-AT. $\left.\cdot \mathrm{L}^{-1} \cdot \mathrm{dia}^{-1}\right)$, o que demonstra a possibilidade de redução no tempo de maturação, como também observado Kamimura (2002).

Os resultados observados no início da maturação dos sistemas (primeiras 72h) denotaram um consumo de amônia e/ou uma maior diluição no sistema de tanques, possivelmente devido à capacidade (volume) 155\% maior do filtro deste sistema para água e substrato quando comparado ao filtro dos aquários, e ao maior volume de água em todo o sistema, que comportava 2,6 vezes mais água que o sistema de aquários. No entanto, durante todo o período de maturação (34 dias), as concentrações de N-AT apresentadas nos dois sistemas permaneceram estáveis e muito próximas do valor encontrado na água marinha antes da adição de solução estoque (aproximadamente $2 \mu \mathrm{g} \mathrm{N}-\mathrm{AT} \cdot \mathrm{L}^{-1}$ ) e, abaixo do pico de amônia (140 $\mu \mathrm{g} \mathrm{N}$-AT.L-1 ${ }^{-1}$ ) observado durante a maturação por Kamimura (2002).

Quanto ao $\mathrm{N}-\mathrm{NO}_{2}$ observado no sistema de aquários, este sugere ciclos de acúmulo e posterior consumo biológico, uma vez que bactérias Nitrobacter, responsáveis pelo processo de nitrificação de nitrito para nitrato, apresentam um maior tempo para colonização do substrato, comparado as Nitrosomonas, responsáveis pela transformação da amônia para nitrito (STICKNEY, 1979). O valor máximo observado de $3,5 \mu \mathrm{g} \mathrm{N}-\mathrm{NO}_{2} \cdot \mathrm{L}^{-1}$ encontra-se também abaixo do 
observado por Kamimura (2002) $\left(80 \mu \mathrm{g} \mathrm{N}-\mathrm{NO}_{2} \cdot \mathrm{L}^{-1}\right)$. No entanto, as observações dos picos de concentração (amônia e nitrito) mais baixos devem considerar que a concentração máxima de amônia no estudo de Kamimura (2002) era maior à observada neste trabalho.

Assim, as reduzidas e estáveis concentrações observadas para amônia em ambos os sistemas, bem como as concentrações de nitrito no sistema de aquários e a ausência deste composto no sistema de tanques podem também estar relacionadas ao dimensionamento dos filtros biológicos. Segundo Griessinger et al. (1989 apud DANIELS et al., 1992), o biofiltro deve comportar aproximadamente $6 \%$ do volume dos tanques (ou aquários), no entanto, o presente estudo utilizou filtros de $24 \%$ (sistema de aquários) e $13 \%$ (sistema de tanques), fato que provavelmente auxiliou a eficácia dos mesmos na remoção da amônia e nitrito.

\section{2. Manutenção dos sistemas e qualidade da água}

Os valores de temperatura, salinidade e pH monitorados após a chegada dos animais apresentaram-se relativamente estáveis. Comparando os valores observados neste período com a fase de maturação dos sistemas, foi possível verificar uma menor variação nos valores de salinidade após a chegada dos animais. Tal fato é explicado pela ocorrência de uma substituição parcial de água por outra de salinidade inferior durante a maturação, devido à um extenso período de chuvas na região de coleta (Ubatuba/SP).

Com relação à temperatura, ainda cotejando os resultados observados após a chegada dos animais com o período de maturação dos sistemas, a menor variação verificada no período com animais pode ser explicada pela adição de 
mais um aquecedor termostatizado em cada sistema, o que melhorou o controle da mesma. Já o pH apresentou uma maior oscilação em função da presença dos animais, que diminuíram a estabilidade do equilíbrio entre as concentrações de oxigênio e dióxido de carbono dissolvidos na água, através da respiração e do aumento da matéria orgânica nos sistemas (excreção e sobras de alimento), desta forma, reduzindo também os valores de $\mathrm{pH}$ observados mesmo com a adição de aeradores nos filtros biológicos dos sistemas.

No monitoramento dos compostos nitrogenados foram observados, em ambos sistemas, picos de NA-T (0,009 mg/L e 0,008 mg/L), que representam cada $0,47 \mu \mathrm{g}$ de $\mathrm{N}-\mathrm{NH}_{3}$, no entanto, tais valores estão bem abaixo do menor valor proposto como nível de segurança para peneídeos $(0,55 \mathrm{mg} \mathrm{N}-\mathrm{AT} / \mathrm{L}$ e 0,03 mg N$\mathrm{NH}_{3} / \mathrm{L}$ ), referentes à pós-larvas de $F$. paulensis (OSTRENSKY \& WASIELESKY, 1995) (Tabela 2), ou seja, organismos mais sensíveis aos encontrados nos sistemas do presente trabalho, camarões com aproximadamente $2 \mathrm{~g}$ (aquários) e 6,7g (tanques), no momento de ocorrência dos picos. Os picos de amônia observados também estão abaixo da média semanal $(0,31 \mathrm{mg} / \mathrm{L})$ obtida por Amaya et. al, (2007) em cultivo de L. vannamei em tanques de recirculação semifechados, com trocas diárias de água.

Para $\mathrm{N}-\mathrm{NO}_{2}$, as maiores concentrações observadas $\left(0,15 \mathrm{mg} \mathrm{N}-\mathrm{NO}_{2} / \mathrm{L}\right.$ e 0,10 mg $\left.\mathrm{N}-\mathrm{NO}_{2} / \mathrm{L}\right)$ também situaram-se abaixo do nível de segurança recomendado $\left(10,2 \mathrm{mg} \mathrm{N}-\mathrm{NO}_{2} / \mathrm{L}\right)$ para juvenis $(170 \pm 45 \mathrm{mg}$ peso individual) de $F$. paulensis (CASTANÕ, 1997 apud WASIELESKY, 2000; SACHSIDA, 1997 apud WASIELESKY, 2000) e observado por Wasielesky (2000) como causador de 
efeitos crônicos a sobrevivência (Tabela 2). A análise de $\mathrm{N}-\mathrm{NO}_{3}$ também resultou em médias $\left(1,16 \mathrm{mg} \mathrm{N}-\mathrm{NO}_{3} / \mathrm{L}\right.$ e $\left.1,12 \mathrm{mg} \mathrm{N}-\mathrm{NO}_{3} / \mathrm{L}\right)$ muito abaixo do nível de segurança (323 mg N-NO $/$ L) e da concentração de efeitos crônicos ao crescimento $\left(80,7 \mathrm{~N}-\mathrm{NO}_{3} / \mathrm{L}\right)$ recomendado e verificado por Wasielesky (2000) (Tabela 2).

Tanto para amônia como para nitrito, os picos observados são decorrentes de acúmulo de matéria orgânica, sendo que os picos do $132^{\circ}$ dia nos tanques devem-se a um aumento do número de camarões devido a retirada destes dos aquários, para limpeza. Após o início da substituição da alimentação (dia 210), a redução observada nas concentrações destes compostos nos sistemas ocorreram devido às sifonagens (com substituição da água retirada) realizadas semanalmente neste período, e, durante os testes de digestibilidade, em dias intercalados.

O resultado da análise de carbonato de cálcio com kit comercial durante a aclimatação às dietas e teste de digestibilidade demonstrou que os sistemas apresentavam concentrações $\left(71-107 \mathrm{mg} \mathrm{CaCO}_{3} . \mathrm{L}^{-1}\right)$ nas quais $L$. vannamei apresenta crescimento (WYK \& SCARPA, 1999). Segundo Boyd (2001), a alcalinidade total expressa como dureza de $\mathrm{CaCO}_{3}$ é a concentração de todas as bases presentes na água (hidróxido, amônia, borato, fosfato, silicato, bicarbonatos e carbonatos). Na água do mar a concentração média da alcalinidade total é aproximadamente $120 \mathrm{mg} / \mathrm{L}$ e em cultivos é recomendado concentrações acima de $75 \mathrm{mg} / \mathrm{L}$, as quais ocorrem principalmente na forma de bicarbonatos e carbonatos. Estes minerais são considerados macro-minerais, pois são requeridos pelos camarões em grandes quantidades, enquanto os micro-minerais em 
pequenas quantidades, e na maioria dos animais aquáticos são absorvidos diretamente da água pelas brânquias e superfície do corpo (AKIYAMA et al., 1992; SHIAU, 1998).

Com relação à comparação entre os resultados (amônia, nitrito, nitrato) provenientes das análises espectrofotométricas e dos kits comerciais, esta permitiu a utilização relativamente segura destes kits como preventivos e/ou indicativos de alguma alteração, mas não para quantificações precisas, onde devem ser empregados os métodos espectrofotométricos.

De maneira geral, percebe-se que apesar da elevação dos compostos nitrogenados mais tóxicos, amônia e nitrito, em alguns períodos, estes picos de concentração apresentaram-se abaixo dos valores de segurança propostos na bibliografia, o que demonstra a eficácia, dos sistemas e da manutenção empregada, na retirada destes, controlando, desta forma, a qualidade da água. Além disto, foi possível verificar também que os sistemas e a manutenção empregada mantiveram relativamente estáveis os parâmetros observados $\left(\mathrm{T}^{\circ}, \mathrm{S} \%\right.$ o e $\mathrm{pH}$ ), como citado anteriormente. Tais observações denotam que sistemas fechados de recirculação de água marinha são ambientes favoráveis ao crescimento de animais experimentais, como observado durante o período com alimentação comercial, embora sejam ambientes laboratoriais.

\section{3. Cultivo dos organismos experimentais}

As baixas taxas de crescimento no início do cultivo e a alta mortalidade apresentada no mesmo período (Tabelas 7 e 9) são indicativas de algum tipo de estresse afetando os animais. Considerando que a qualidade da água era mantida 
adequada e que os parâmetros observados não apresentaram grandes oscilações, i.e., o ambiente apresentava-se estável (item 3.6.), os fatores negativos existentes foram a elevada densidade (525 e 1350 indivíduos $/ \mathrm{m}^{2}$ nos tanques e 400 indivíduos $/ \mathrm{m}^{2}$ nos aquários) e o intervalo entre as ofertas de alimento, 3 refeições com intervalos de: $6 \mathrm{~h}, 6 \mathrm{~h}$ e $12 \mathrm{~h}$.

Segundo Amaral et. al (2003), na fase de berçário, referência comercial para o período avaliado acima $(<3 \mathrm{~g})$, em viveiros escavado as pós-larvas de camarão permanecem em densidades de 150 a 200 indivíduos $/ \mathrm{m}^{2}$, alimentadas com ração uma vez ao dia, além do alimento vivo disponível. Além destes viveiros, existem ainda os berçários intensivos em tanques de concreto, com aeração, fertilização e, como alimento, biomassa de Artemia e ração a cada duas horas. Neste tipo de berçário, as densidades são mais elevadas, alcançando 20-30 PLs/L. Nota-se que as pós-larvas deste trabalho estavam em densidades acima das observadas em tanques escavados e, apesar das condições controladas, a freqüência alimentar era reduzida, embora em quantidades adequadas. Wyk (1999) recomenda intervalos de alimentação de 2 à $3 h$ para pós-larvas de $L$. vannamei, devido às elevadas taxas metabólicas e a pequena capacidade de estocagem de alimento em seu sistema digestivo apresentadas nesta fase. Assim, a combinação de altas densidades e longos intervalos entre as ofertas de alimento favoreceu a ocorrência de canibalismo, pois nesta fase de crescimento, apenas as altas densidades não afetariam a sobrevivência, somente o crescimento, como reportou Al-Ameeri \& Cruz (2006) avaliando a produção e o rendimento de $P$. semisulcatus em fase de crescimento $(0,08 \mathrm{~g})$ e engorda $(5 \mathrm{~g})$. No referido estudo, somente a fase de engorda teve o crescimento e a sobrevivência afetada 
negativamente pela densidade. Com relação à freqüência alimentar, Smith et al. (2002) em estudo com $P$. monodon de 5,6g não observou efeitos da mesma no crescimento, como ocorre com indivíduos mais jovens.

Altas densidades afetam a sobrevivência, principalmente em períodos de muda, quando os animais estão mais susceptíveis ao canibalismo (WASIELESKY, 2000), além de causar estresse aos animais, afetando o sistema imunológico dos mesmos e favorecendo o surgimento de enfermidades, como a observada (NIM), entre outras (FONSECA et al., 2004). Krummenauer et al. (2006), avaliando diferentes densidades de $F$. paulensis (peso médio: 4,95g) cultivados em gaiolas em estuário demonstraram o efeito negativo da densidades sobre o crescimento dos camarões. A densidade ideal pode variar em função da espécie, das estratégias de manejo do cultivo e de parâmetros ambientais (WASIELESKY, 2000).

Portanto, no início do cultivo, a baixa sobrevivência está relacionada às densidades elevadas juntamente com os intervalos de alimentação e às diferenças entre as taxas de crescimento dos sistemas devem-se à seleção dos animais por tamanho em PL70.

Após PL70, o aumento da taxa de crescimento nos aquários, mesmo sob altas densidades, pode ser explicado pela seleção de animais ocorrida após a realocação por tamanho, fato que também pode ter contribuído para esta taxa ser maior do que nos tanques, onde apesar das baixas densidades $(26,19$ indivíduos $/ \mathrm{m}^{2}$ ), estavam os indivíduos médios. Ainda que com taxa de crescimento mais elevada, a sobrevivência nos aquários foi baixa entre PL70 e PL106, mesmo apresentando um aumento de 2,9 vezes em relação à sobrevivência no período 
anterior (PL20-PL70). Este aumento seria justificado pela redução da densidade neste período comparada ao anterior, de uma média de 400 indivíduos $/ \mathrm{m}^{2}$ (PL20PL70) para 63 indivíduos $/ \mathrm{m}^{2}$ (PL70-PL106). Neste período (PL70-106), a sobrevivência apresentada $(46,25 \%)$ esta de acordo com a sobrevivência observada em cultivos comercias semi-intensivo de L. vannamei, com pós-larvas da mesma idade e produzidas em laboratório (JORY, 1995 apud NUNES, 2000).

Nos tanques, os mesmos fatores podem explicar os resultados observados: a baixa taxa de crescimento após PL70 ocorreu devido, principalmente, a seleção por indivíduos médios, uma vez que as densidades já se encontravam mais baixas (PL70), este fato, por sua vez, elevou a sobrevivência.

Em ambos os sistemas, a elevação da taxa de sobrevivência próxima da recomendada por Akiyama (2005) para testes nutricionais, mínimo de 85\%, só ocorreu a partir de PL106, quando as densidades médias alcançaram cerca de 29 e 34 indivíduos $/ \mathrm{m}^{2}$ nos aquários e tanques, respectivamente. Embora os organismos estivessem confinados em ambiente artificial e sem alimento natural disponível, as taxas de crescimento apresentadas após $3 \mathrm{~g}$ no sistema de aquários, também estavam próximas da taxa recomendada $(0,9 \mathrm{~g} / \mathrm{semana})$ para testes nutricionais em crustáceos (AKIYAMA, 2005), sendo que nos sistemas de tanques as taxas observadas neste período foram sempre maiores que 0,9 g/semana, apesar de nem sempre serem significativamente diferentes das taxas do sistema de aquários. A não observação de diferenças entre algumas taxas de crescimento pode ser explicada pela elevada variabilidade dos dados, principalmente proveniente dos aquários, com coeficientes de variação entre $25 \%$ e $52 \%$, enquanto nos tanques, este coeficiente esteve sempre abaixo de $15 \%$, 
como recomendado por D’Abramo \& Castell (1997) para respostas à tratamentos alimentares, mas ainda acima do sugerido por Akiyama (1992, apud D'ABRAMO \& CASTELL, 1997) (10\%).

Considerando todo o período de cultivo com ração comercial, a partir de PL106, quando as densidades estavam mais baixas e a alimentação próxima (3 refeições/dia) do recomendado por Wyk (1999), i.e., 4 refeições para indivíduos com peso acima de $1 \mathrm{~g}$, os resultados de peso médio final, ganho de peso e taxa de crescimento (tanques > aquários) indicam um desempenho inferior dos camarões cultivados no sistema de aquários e a recuperação dos indivíduos médios alocados no sistema de tanques. Tais observações demonstram a melhor qualidade dos tanques para crescimento, apesar dos animais estarem em maiores densidades do que as mantidas nos aquários (mas em baixas densidades em ambos sistemas).

No caso do sistema de tanques, mesmo com a seleção de animais maiores para o sistema de aquários, ocorrida em PL70, o peso final dos animais e a taxa de crescimento durante o período de PL106 à PL217, ou nos intervalos de 30 dias, ainda foram maiores, evidenciado sua maior adequabilidade para testes deste sistema em relação aos aquários. Os dados de peso final e inicial destacam isto, embora com elevada variabilidade em PL106, foi possível observar que o peso nos tanques era significativamente $(P<0,05)$ menor $(1,77 g)$ que nos aquários (2,91g), e, mesmo assim, resultou em peso final e ganho de peso significativamente maiores $(P<0,05)$ nos tanques, $15,40 \%$ e $35,70 \%$, respectivamente. 
Tais observações vêm de encontro à questão das diferenças entre os sistemas para o crescimento dos animais: área de superfície do fundo, volume de água e taxa de recirculação, além de imputar maior confiabilidade dos dados oriundos do sistema de tanques, uma vez que o coeficiente de variação apresentado por este sistema para peso final $(11,61 \%)$ foi menor comparado ao sistema de aquários (18,50\%). Como já citado, D’Abramo \& Castell (1997) e Akiyama (1992 apud D'ABRAMO \& CASTELL, 1997) sugerem coeficientes de variação máximos de $15 \%$ e $10 \%$, respectivamente, valores que podem ser observados no sistema de tanques no caso do peso final, embora um pouco acima do recomendado por Akiyama (1992 apud D'ABRAMO \& CASTELL, 1997). A alta variabilidade dos dados reduziu a possibilidade de identificação de diferenças estatísticas entre as dietas durante o teste de digestibilidade.

A elevada variância na distribuição do peso é uma característica dos crustáceos e da maioria das espécies aquáticas, principalmente quando cultivadas em grupo (e.g. Macrobrachium rosenbergii), e pode ser explicada pelo crescimento diferencial, não contínuo destes organismos. Esta característica é conhecida com crescimento densidade-dependente e pode ocorrer mesmo em indivíduos cultivados individualmente (D’ABRAMO \& CASTELL, 1997; D’ABRAMO et. al, 1988). Nos presente trabalho, a variabilidade observada nos aquários e tanques parece ser resultado da densidade de biomassa por volume ao invés do cultivo em grupo, uma vez que os sistemas apresentaram variâncias diferenciadas e em ambos sistemas os camarões estavam agrupados, mas com densidades divergentes como será explicitado a seguir. 
Durante o cultivo com ração comercial os camarões em ambos os sistemas foram mantido em grupo, apenas a partir de PL217, dois aquários continham dois camarões, os demais foram mantido individualmente. Os tanques permaneceram com indivíduos agrupados durante todo o trabalho. Assim, considerando que neste período (ração comercial), os cultivos eram agrupados, as diferenças que podem ter afetado diferencialmente o crescimento nos sistemas, estão relacionadas, como já citado, ao volume de água e à área de superfície, 11 e 3,5 vezes, respectivamente, maiores nos tanques do que nos aquários. A taxa de recirculação era diferenciada também, mas 6,3 vezes menor nos tanques. Estas observações concordam com o verificado por D'Abramo et al. (2000) avaliando $M$. rosenbergii cultivados individualmente (química e fisicamente isolados), quando da ocorrência de pesos maiores alcançada com baixas taxas de recirculação, mas com área de superfície aumentada. Os autores ainda observaram que o ganho de peso é maximizado com o aumento simultâneo do volume e da área de superfície, e não somente com uma dessas características isoladas.

O volume e a área de superfície de fundo afetam a densidade de biomassa (standing crop) (peso total/volume de água), que esta relacionada ao crescimento densidade-dependente observado nos organismos cultivados individualmente (sob controle abiótico e alimento abundante) no trabalho de D’Abramo et al. (2000), onde o máximo ganho de peso é alcançado sob determinada densidade de biomassa (standing crop) (peso/volume de água), como definido anteriormente por Duarte et al. (1987 apud D'ABRAMO et al. 2000), para crustáceos e outros organismos aquáticos. Os autores, comparando 
temporalmente áreas e volumes distintos de cultivo, estimaram em condições laboratoriais como início da resposta negativa ao crescimento, a densidade de aproximadamente $0,5 \mathrm{~g} / \mathrm{L}$ e extrapolaram este valor em $0,87 \mathrm{~g} / \mathrm{L}$ e $1,13 \mathrm{~g} / \mathrm{l}$ para campo.

No presente estudo, observando os dados apresentados pelos sistemas de tanques e aquários, é possível perceber que nos aquários a taxa de crescimento estabilizou a partir de PL139, em cerca de 0,7 g/semana, sem diferenças significativas até PL217. Neste período (estabilização), as densidades de biomassa estavam entre 0,5g/L e 0,8g/L e, quando alcançou 1,1g/L (PL217), a taxa de crescimento foi reduzida significativamente $(P<0,05)$. Amaya et al. $(2007)$ observaram taxas de crescimento de 1,4g/semana à 1,6g/semana em cultivo semi-fechado com L. vannamei, o que evidencia o baixo crescimento nos aquários, e de acordo com Akiyama (2005), não adequados para testes nutricionais pois estão abaixo de 0,9g/semana. Nos tanques, a taxa de crescimento estabilizou-se a partir de PL106 (aproximadamente 1g/semana), quando as densidades variavam de $0,1 \mathrm{~g} / \mathrm{L}$ a $0,7 \mathrm{~g} / \mathrm{L}$, sem diferenças significativas até PL238. Em PL217 a taxa de crescimento já era menor, mas não significativamente, neste ponto a densidade estava entre $0,7 \mathrm{~g} / \mathrm{L}$ e $0,5 \mathrm{~g} / \mathrm{L}$. Assim pode-se concluir que as densidades que afetaram o crescimento, em ambos os sistemas estavam entre $0,5 \mathrm{~g} / \mathrm{L}$ e $0,8 \mathrm{~g} / \mathrm{L}$, e as densidades críticas, onde não há o efeito negativo sobre o crescimento, próxima de $0,5 \mathrm{~g} / \mathrm{L}$, i.e, próxima do obtido por D’Abramo et al.(2000) em laboratório. No entanto, deve-se levar em consideração que os indivíduos no presente estudo eram cultivados em grupo e, assim, interferências físicas (visuais e táteis) e químicas ocorriam, afetando também o 
crescimento, portanto, estes valores podem ou não estar sobre ou subestimados, dependendo do efeito (positivo ou negativo) da atividade social para esta espécie, como cita D'Abramo et al.(2000).

A utilização de indivíduos isolados, sem contato até mesmo com a água proveniente de outro compartimento individual, para pesquisa nutricional com crustáceos, é defendida por diversos autores (D’ABRAMO \& CASTELL, 1997; D'ABRAMO et. al, 1998; D'ABRAMO et. al, 2000), embora não haja nenhum estudo com L. vannamei. O isolamento tem por objetivo evitar interações intraespecíficas que afetem o crescimento (e.g. químicas, táteis, canibalismo), além de facilitar a obtenção de réplicas. No entanto, D’Abramo \& Castell (1997) reconhecem que o isolamento individual pode causar estresse à animais que são sociais na natureza, afetando o crescimento, a saúde ou o metabolismo destes animais, o que levaria à interpretações errôneas das respostas provenientes de testes nutricionais.

Com relação aos resultados observados para consumo de ração em relação à biomassa corporal dos camarões, estes concordam com os dados apresentados pela literatura com relação ao maior consumo de alimento observado nos camarões menores, devido a maior taxa metabólica apresentada por estes (DALL et al. 1990; AKIYAMA et. al, 1997; WYK, 1999). E embora com valores mais elevados que as tabelas de alimentação apresentadas como guias para cultivos comerciais (WYK, 1999; NUNES, 2000), a oferta de alimento neste estudo deu-se em função da demanda, uma alternativa que garantiu taxas de alimento adequadas às condições de cada sistema. 


\section{4. Lixiviação das dietas}

O resultados de lixiviação de $\operatorname{Cr}(22,8 \%$ à $31,6 \%)$ e $\mathrm{PB}(3 \%$ à $9,6 \%)$ demonstraram perdas maiores de $\mathrm{Cr}$ em relação à $\mathrm{PB}$, indicando que se a DAPB fosse calculada sem considerar a taxa de lixiviação em ambos os compostos, os resultados seriam de 4 a 6,5 pontos de porcentagem mais baixos (subestimados), pois a redução pela lixiviação seria contabilizada como não assimilação pelos camarões, uma vez que o cálculo da DAPB, utilizando o marcador inerte, é baseado na proporção entre PB e Cr nas dietas e nas fezes. Assim, a observação de concentrações elevadas de PB e $\mathrm{Cr}$ nas dietas ingeridas e pequenas quantidades nas fezes (que ocorreria se não fosse contabilizada a lixiviação por imersão), indicaria pequeno aproveitamento em relação à proporção disponibilizada na dieta. Desta forma, a taxa de lixiviação descontada das concentrações de PB e Cr minimiza o erro no cálculo da DAPB ao aproximar as concentrações de PB e Cr do valor real ingerido pelos camarões.

Durante este teste, a lixiviação ocorre desde a permanência da dieta na água marinha, durante a oferta de alimento aos camarões, até a retirada do aquário por sifonagem, lavagem com água destilada e duas transferências para recipientes diferentes. Portanto, a lixiviação calculada pode subestimar as concentrações de $\mathrm{PB}$ e $\mathrm{Cr}$ ingeridas pelos camarões nas dietas, pois ela é aumentada pela manipulação descrita acima, elevando o resultado de DAPB. No entanto, as fezes utilizadas no cálculo da DAPB são igualmente manipuladas, embora sofram menor lixiviação devido à presença da membrana peritrófica (DALL et. al, 1990), o que faz a compensação não ser total à lixiviação por imersão causada nas dietas, resultando em valor sobreestimado de DAPB, 
embora menor que o valor resultante se a lixiviação ocorresse apenas no alimento ingerido, ou seja, a lixiviação por manipulação das fezes reduz o erro por manipulação das dietas, mas não o elimina totalmente.

Os resultados de lixiviação observados $(\mathrm{Cr}>\mathrm{PB})$ apresentam certas discordâncias dos dados apresentados por Smith \& Tabrett (2004) ao estudarem a metodologia na análise de digestibilidade in vivo. Os autores encontraram pequena lixiviação de PB (1\%) e aumento da concentração de $\operatorname{Cr}(8,6 \%)$ nas dietas após imersão durante 40 min., o que pode sobreestimar os dados de DAPB. Por outro lado, Cuzon et al. (1982) observaram em 30 min. perdas de PB (8\%) mais aproximadas das observadas no presente estudo ( $3 \%$ a $9,6 \%$ ) e o método de análise também foi mais similar.

A lixiviação pode reduzir a qualidade da água em um sistema de cultivo, bem como o crescimento, a taxa de conversão alimentar e a sobrevivência dos animais cultivados (OBALDO et al., 2002). A desintegração de um pellet e a lixiviação de seus nutrientes estão relacionadas à baixa estabilidade das dietas (TACON, 2002), que é função do processamento empregado na fabricação, tipos de ingredientes utilizados, inclusive aglutinantes e, de materiais de cobertura (e.g. microcápsulas) (OBALDO et al, 2002).

No presente estudo, o processo de extrusão foi utilizado uma vez, enquanto Smith \& Tabrett (2004) utilizaram dieta duas vezes extrusada. Com relação aos ingredientes utilizados, principalmente os que possuem propriedades aglutinantes, como farinha de trigo e glúten, empregou-se quantidades menores $(7,5 \%)$, comparado ao trabalho acima citado. Outro ingrediente que pode ter influenciado a estabilidade das dietas é a soja, que reduz a estabilidade do pellet 
com o incremento das concentrações (LIM \& DOMINY, 1990). Segundo Swick (2002, 2007), o elevado conteúdo de fibra, principalmente da casca, afeta a digestibilidade da soja em peixes, diminuindo a qualidade e a estabilidade da ração. No entanto, mesmo sem casca o farelo de soja parece apresentar baixa propriedade aglutinante, devido as pequenas concentrações de carboidratos aglutinantes (e.g. amido), geralmente abaixo de 1\% (SNYDER \& KWON, 1987 apud LIM \& DOMINY, 1990).

\section{5. Teste de digestibilidade protéica das dietas}

Durante o teste de digestibilidade foi observada visualmente a distribuição heterogênea de óxido crômico nas fezes: a coloração era mais verde nas primeiras três horas de coleta do que no segundo período de três horas, como também verificado por Smith \& Tabrett (2004) ao analisar as concentrações de Cr e PB, temporalmente, nas fezes de $P$. monodon. Os autores ainda demonstraram que a taxa de passagem destes compostos pelo trato digestivo é similar. Esta correlação entre a taxa de passagem do marcador e da PB também foi observada em abalôneas por Shipton \& Britz (2001), como recomendado por Sugiura (2000) para concluir se um marcador é capaz de predizer a digestibilidade de determinado nutriente. Ishikawa et al. (1996 apud SHIPTON \& BRITZ, 2001) avaliando a digestibilidade em $P$. japonicus observou passagem diferencial entre o óxido crômico e carboidratos e, portanto, a inadequabilidade deste marcador para predizer a digestibilidade de carboidratos nesta espécie, mas adequada para PB. Assim, embora o presente estudo não tenha verificado a relação entre a taxa de passagem do óxido crômico e a PB, foi feita a coleta total das fezes a fim de 
minimizar ao máximo a possibilidade de erro devido à distribuição não homogênea do óxido crômico, como recomenda Smith \& Tabrett (2004).

A heterogeneidade na passagem do marcador de óxido crômico pelo sistema digestivo também foi observada em outros animais aquáticos, como lagostas (LEAVITT, 1985), abalôneas (SHIPTON \& BRITZ, 2001) e peixes (TACON \& RODRIGUES, 1984). Tais observações confrontam com o exposto por Lee \& Lawrence (1997) ao revisar a metodologia com marcador de óxido crômico, os quais citam trabalhos de digestibilidade com camarões, inclusive L. vannamei, nos quais o óxido crômico parece ser homogêneo nas fezes.

Com relação aos valores de DAPB apresentados pelos camarões $L$. vannamei em ambos os sistemas (aquários: $78,8 \%$ - 80,9\% e tanques: $80,3 \%$ $84 \%$ ), alimentados com dietas utilizando $17 \%$ de farinha de peixe e $30,9 \%-37, \%$ de diferentes tipos de soja (PB total: 33,6\%, Cr:0,3\%) como fontes protéicas principais, estes encontraram-se próximos aos valores mais baixos de DAPB observados na literatura em testes utilizando como marcador inerte o óxido crômico (0,5\%). Smith \& Tabrett (2004) ao analisar os métodos de análise da digestibilidade (marcador e gravimétrico) em experimentos com $P$. monodon (fonte protéica: $9,3 \%$ de farelo de soja e $30 \%$ de farinha de peixe), encontraram coeficientes variados de DA $(81,5 \%$ a $92 \%)$ dependendo da metodologia empregada, sendo que os valores mais baixos foram observados em fezes coletadas em 1h, $2 \mathrm{~h}$ e 3h (DAPB: 84\%) após a evacuação, valor igual à máxima DAPB verificada nos sistemas no presente trabalho, embora em outra espécie de peneídeo. Os maiores valores de DAPB foram observados em coletas de $6 \mathrm{~h}$ e $12 \mathrm{~h}$ após a evacuação, quando houve o aumento da concentração de Cr. Cousin et al. 
(1996) analisando a digestibilidade de diferentes carboidratos (PB total: $30 \%$ 36\%) com óxido crômico em $L$. vannamei encontraram valores mais elevados de DAPB (94\% a 98\%), mas estas dietas não continham soja como fonte protéica, apenas farinha de peixe. Smith et al. (1985) avaliando o crescimento e a digestibilidade em tamanhos variados de L. vannamei sob diferentes níveis e fontes protéicas observaram em indivíduos grandes (>20g) DAPB entre $78,7 \%$ a $85,4 \%$ (Cr: $0,85 \%$ a $1,3 \%$ ), valores mais próximos ao observado no presente estudo. Os camarões do referido estudo estavam em densidade entre $0,5 \mathrm{~g} / \mathrm{L}$ e 0,9g/L, como também no presente trabalho e, com taxas de crescimento também similares $(0,7 \mathrm{~g} /$ semana), o que corrobora com os dados de DAPB apresentados no presente estudo.

Divakaran et al. (2000) observaram de $89,5 \%$ a $94,5 \%$ de DAPB (PB total: $44 \%$, farinha de peixe: $30 \%, 25,5 \%, 21 \%$ e farelo de soja: $24 \%, 35 \%, 46 \%$ ), aumentando com o incremento da soja. Os autores também verificaram o aumento da DAPB e de matéria seca com o aumento concomitante da porcentagem de óxido crômico $(0,5 \%$ e $1 \%)$ e do farelo de soja nas dietas, sugerindo uma possível interação física entre estes compostos (diferentes níveis de farelo de soja não afetaram consistentemente a DA deste ingrediente) e a limitação do método. Tacon \& Rodrigues (1984) já haviam observado tal efeito na DAPB de dietas (farelo de trigo: $8,5 \%, 11,5 \%$ e $13 \%$; farelo de soja: $10 \%$; Cr: $0,9 \%, 2 \%, 4,2 \%$ ) em trutas e sugeriram que o óxido crômico passa mais rápido pelo trato gastrointestinal que o nutriente avaliado. No entanto, neste trabalho a DAPB foi significativamente maior apenas com $4 \%$ de óxido crômico, ou seja, até $2 \%$ não foi observado aumento significativo da DAPB. Neste sentido, Smith \& Tabrett (2004) 
recomendam concentrações baixas de marcador inerte nas dietas a serem testadas, tal como foi utilizado neste trabalho.

Embora não tenha sido observado diferenças significativas $(P>0,05)$ entre as dietas testadas nos aquários e, nos tanques não tenha sido possível a aplicação de análise estatística, é possível verificar que a seqüência das respostas de L. vannamei (DAPB e crescimento) às dietas testadas, diferiram entre si, tanto nos aquários (DAPB: FS > FSM > FST, crescimento: FST > FS > FSM), como nos tanques (DAPB: FSM > FST > FS, crescimento: FS > FSM > FST). Frente esta situação, possivelmente outros fatores (e.g. palatabilidade, perfil de aminoácidos, ingestão) influenciem mais o crescimento do que a digestibilidade, assim como sugere Forster et al. (2003), ao verificar tais discordâncias entre digestibilidade e crescimento em L. vannamei. Considerando a DAPB obtida nos tanques, uma vez que este sistema demonstrou-se adequado para o crescimento dos camarões, que apresentaram taxas de crescimento acima do recomendado para testes nutricionais, outro fator que merece observação é que a DAPB acompanhou o maior tratamento dos farelos de soja (micronizado $>$ texturizado $>$ tostado). Tal fato pode indicar que o processamento aumente a digestibilidade da PB como já verificado por outros autores (BELLAVER \& SNIZEK; 1999; MENDES et al., 2004; SWICK, 2007).

Durante o teste de digestibilidade os camarões estavam alocados individualmente nos aquários e em grupo nos tanques, mas a densidade (biomassa/L) em ambos os sistemas (aquários: $1 \mathrm{~g} / \mathrm{L}$ e tanques: 0,5-0,7g/L) estava acima da observada no presente estudo como densidade crítica $(0,5 \mathrm{~g} / \mathrm{L})$ (onde aparentemente não havia influência no crescimento). Nesta fase, a taxa de 
crescimento reduziu em ambos os sistemas, mas além da densidade elevada teve início a oferta das dietas experimentais, com teores de soja (30,9\%-37\%) maiores que as concentrações de soja geralmente presentes em ração comercial (20\%25\%) (SWICK, 2007). Assim, a redução no crescimento pode ter sido tanto função das altas densidades de biomassa, como do incremento de soja, que já verificado em L. vannamei pode reduzir a ingestão de ração e, conseqüentemente, o crescimento (LIM \& DOMINY, 1990).

Comparando os sistemas, com relação ao incremento de peso durante o teste de digestibilidade, observou-se o mesmo comportamento apresentado durante o cultivo para crescimento dos animais, i.e., maiores médias de peso e crescimento nos tanques em comparação aos aquários, no entanto, sem diferenças significativas entre as dietas para nenhum parâmetro de crescimento avaliado em ambos os sistemas. Os coeficientes de variação no sistema de aquários continuaram elevados (11,8\% à $112,6 \%)$, sendo que para peso inicial e final da dieta FS $(15,3 \%$ e $11,8 \%)$, estes ainda encontravam-se próximos do recomendado por D’Abramo \& Castell (1997) (15\%). Nos tanques a variação foi menor para pesos inicial e final (abaixo de 10\%), como durante o cultivo para crescimento, com exceção do peso final na dieta FS $(10,1 \%)$ e dos pesos inicial e final na dieta FST $(19,1 \%$ e $20,1 \%)$, esta última apresentou coeficientes de variação muito próximos aos observados para esta dieta nos aquários (19,05 e $21,3 \%$ ). Portanto, nos tanques a variabilidade foi em sua maioria dentro da recomendada por D'Abramo \& Castell (1997) $(\leq 15 \%)$ e pouco acima do recomendado por Akiyama (1992, apud D'ABRAMO \& CASTELL, 1997) (<10\%). Nota-se que a elevada variabilidade, juntamente com o reduzido número de 
réplicas, dificultou a diferenciação estatística dos resultados de crescimento entre as dietas nos aquários, que apresentou apenas uma dieta com coeficiente de variação reduzido (FS), além de taxas de crescimento abaixo do recomendado por Akyiama (2005). Por outro lado nos tanques, a menor variabilidade e taxa de crescimento adequada pode indicar bons resultados de DAPB.

A elevada variabilidade observada durante o teste de digestibilidade, que dificulta a comparação entre as respostas de crescimento apresentadas pelos camarões frente às dietas testadas, advém do crescimento descontínuo apresentado pelos crustáceos, como já citado no item 4.3. O crescimento diferencial é função do maior ganho de peso durante a muda e menor no intermuda (DALL et al., 1990), portanto, para respostas mais adequadas, convém observar, além da densidade e do espaço de cultivo, um maior período experimental, que pode ser delimitado por número de ecdises ou ganho de peso de 300\% em cultivo controle, como sugere D'Abramo \& Castell, 1997.

Durante o teste de digestibilidade também foram observadas diferenças numéricas no coeficiente de digestibilidade entre os sistemas (tanques > aquários). A maior digestibilidade observada nos tanques pode estar relacionada à melhor qualidade (densidade, área de superfície e volume de água) proporcionada aos animais por este sistema, como também verificada para o crescimento. Sabese que a densidade afeta o crescimento (AL-AMEERI \& CRUZ, 2006; KRUMMENAUER et. al., 2006) e, possivelmente pode afetar a digestibilidade, uma vez que diversos fatores estressores têm efeito sobre a digestão de camarões (MUHLIA-ALMAZÁN \& GARCIA-CARREÑO, 2002; CÓRDOVAMURUETA et. al., 2004). Desta forma, é provável que a digestibilidade 
apresentada nos tanques seja mais confiável, uma vez que estes animais apresentavam crescimento adequado para testes nutricionais, como recomendado por Akyiama (2005). Considerando o aspecto metodológico apresentado no presente trabalho, o método de análise da digestibilidade in vitro apresenta-se promissor (LEMOS, 2006; LEMOS \& NUNES, 2007a; LEMOS \& NUNES, 2007b). 


\section{CONCLUSÃO}

O sistema de recirculação de água marinha, juntamente com a manutenção empregada, mostrou-se adequado na manutenção da estabilidade dos parâmetros abióticos monitorados (compostos nitrogenados, temperatura, salinidade e $\mathrm{pH}$ ). No entanto, para o crescimento dos organismos em estudo, conclui-se que a densidade (biomassa/L) como conseqüência do espaço dos sistemas (área de superfície de fundo e volume de água) possivelmente afetou o desempenho dos animais cultivados, principalmente no sistema de aquários, efeitos já observados em outras espécies (AL-AMEERI \& CRUZ, 2006; KRUMMENAUER et al., 2006; D'ABRAMO et. al, 2000), mas não em L. vannamei. No entanto, a taxa de crescimento nos tanques durante cultivo com ração comercial foi acima da recomendada por Akyiama (2005) para testes nutricionais, indicando a adequabilidade deste sistema para o teste de digestibilidade.

Para redução dos efeitos do sistema de cultivo no crescimento recomenda-se a observação da biomassa máxima que não afete o crescimento, além de adequada área de superfície e volume de água, uma vez que peneídeos apresentam hábitos bentônicos durante a maior parte de sua vida (DALL et al., 1990). Quanto ao cultivo isolado ou em grupo, são necessários estudos que verifiquem tal influência em L. vannamei. Embora os organismos no presente trabalho tenham apresentado taxas de crescimento mais elevadas nos tanques, onde estavam durante todo o período agrupados.

Com relação ao experimento de digestibilidade, as dietas utilizadas apresentaram taxas consideráveis de lixiviação, principalmente de marcador de óxido crômico, possivelmente devido ao processamento aplicado na fabricação e 
aos ingredientes utilizados, principalmente a soja, que sabe-se ter influência na diminuição da estabilidade de rações na água, devido ao maior teor de fibras (LIM \& DOMINY, 1990; SWICK 2002, 2007). A soja como ingrediente tem apresentado bons resultados em alguns trabalhos com camarões (DIVAKARAN et al., 2000; PARIPATANANONT et al., 20001; AMAYA et al., 2007) e apresenta um dos melhores perfis de aminoácidos em relação à outros ingredientes vegetais (SWICK, 2002). No presente estudo os coeficientes de DAPB variaram de $79 \%$ à $84 \%$, aumentando conforme o maior processamento do farelo de soja (tostado, texturizado e micronizado), o que pode indicar a maior digestibilidade em produtos mais processados. Os coeficientes de DAPB entre as dietas não foram estatisticamente diferentes nos aquários e, numericamente os intervalo de DAPB foi maior nos tanques, o que sugere, juntamente com a resposta de crescimento, o melhor desempenho do sistema de tanques sobre os camarões para testes de digestibilidade. 


\section{REFERÊNCIAS BIBLIOGRÁFICAS}

ABCC (Associação Brasileira de Criadores de Camarão). Estatísticas Nacionais: Evolução do Desempenho da Carcinicultura Brasileira 1998-2007. 2008a. Disponível em: <http://www.abccam.com.br/>. Acesso em: 4 fev. 2008.

. Histórico da Carcinicultura no Brasil. 2004. Disponível em: <http://www.abccam.com.br/>. Acesso em: 12 abr. 2005.

\section{Estatísticas Internacionais: Principais Países Produtores de Camarão}

Cultivado - 2005. 2008b. Disponível em: <http://www.abccam.com.br/>. Acesso em: 4 fev. 2008.

AKIYAMA, D. M. Challenges for Shrimp Nutrition Research. Aquaculture 2005. Bali: World Aquaculture Society, 2005.

.; WARREN, G. D.; LAWRENCE, A. L. Penaeid Shrimp Nutrition. In: FAST, A.; LESTER, L. J. (Eds.) Marine Shrimp Culture: Principles and Practices. Developments in Aquaculture and Fisheries Science, 23. Holanda: Elsevier, 1992.

AL-AMEERI, A. A.; CRUZ, E. M. Production and yield of Penaeus semisulcatus (de Haan) cultured at different densities. Aquaculture Research, vol. 37, p. 1499-1506, 2006.

AMAYA, E.; DAVIS, D.A.; ROUSE, D.B. Alternative diets for the Pacific White shrimp Litopenaeus vannamei. Aquaculture, vol. 262, p. 419-425, 2007.

AMARAL, R.; ROCHA, I.P.; LIRA, G.P. Alimentação de camarões e consumo de alimentos na carcinicultura: A experiência brasileira. João Pessoa: MCR Aquacultura, 2003. Disponível em: < http://www.mcraquacultura.com.br/arquivos/Manejo\%20Alimentar.pdf>. Acesso em: 16 jan. 2008.

AMINOT, A., CHAUSSEPIED, M. Manuel des analyses chimiques en milieu marin. Brest: C.N.E.X.O, 1983. 
AOAC (Association of Official Agricultural Chemists). Official Methods of Analysis. USA: AOAC, 2000.

BAILEY-BROCK, J.H.; MOSS, S.M. Penaeid Taxonomy, Biology and Zoogeography. Penaeid Shrimp Nutrition. In: FAST, A.; LESTER, L.J. (Eds.) Marine Shrimp Culture: Principles and Practices. Developments in Aquaculture and Fisheries Science, 23. Holanda: Elsevier, 1992.

BAUMGARTEN, M.G.Z.; ROCHA, J.M.B.; NIENCHESKI, L.F.H. Manual de Análises em Oceanografia Química. Rio Grande: FURG, 1996.

BELLAVER, C.; SNIZECK JR., P.N. Processamento da soja e suas implicações na alimentação de suínos e aves. Brasil: EMBRAPA, 1999. Disponível em: $<w w w . c n p s a . e m b r a p a . b r / s g c / s g c \_a r q u i v o s / p a l e s t r a s \_g 0 r 65 h 6 e . p d f>$ Acesso em 05 fev. 2008.

BORGHETTI, N. R. B.; OSTRENSKY, A.; BORGHETTI, J. R. Aqüicultura: Uma visão geral sobre a produção de organismos aquáticos no Brasil e no mundo. Curitiba: Grupo Integrado de Aqüicultura e Estudos Ambientais, 2003.

BORTONE, E. J. Extrusion processing: Part I. Ingredient Functionality of Formulas. Global Aquaculture Advocate, Apr., 2004.

BRADFORD, M.M. A rapid and sensitive method for the quantification of microgram quantities of protein utilizing the principle of protein dye binding. Anal. Biochem., vol. 72, p. 248-254, 1976.

BRITO, R.; CHIMAL, M.E.; GELABERT, R.; GAXIOLA, G.; ROSAS, C. Effect of artificial and natural diets in Litopenaeus setiferus (Linnaeus, 1967) and Litopenaeus vannamei (Boone, 1931) early postlarvae. Aquaculture, Vol. 237, p. 517-531, 2004.

BOYD, C.E. Soil and water quality considerations in shrimp farming. In: HAWS, M.C.; BOYD, C.E. (Eds.) Methods for improving shrimp farming in Central America. Nicaragua: Central America University, 2001. 
BURFORD, M. A.; JACKSON, C. J.; PRESTON, N. P. Reducing nitrogen waste from shrimp farming: an integrated approach. In: BROWDY, C. L.; JORY, D. E. (Eds.). The New Wave. Proceedings of the special Session on Sustainable Shrimp Culture, Aquaculture 2001. USA: World Aquaculture Society, 2001.

CBAA (Compêndio Brasileiro de Alimentação Animal). São Paulo: Sindirações/Anfal. Campinas CBNA/SDR/MA, 2005.

CHAMBERLAIN, G. W. Extruded shrimp feeds reemerge. Global Aquaculture Advocate, Jun. 2004.

CHO, C.Y.; HYNES, J.D.; WOOD, K.R.; YOSHIDA, H.K. Development of high-nutrientdense, low-pollution diets and prediction of aquaculture wastes using biological approaches. Aquaculture, vol. 124, p. 293-305, 1994

CÓRDOVA-MURUETA, J.H.; GARCÍA-CARREÑO, F.L.; NAVARRETE-DEL-TORO, M. DE LOS A. Digestive enzymes present in crustacean feces as a tool for biochemical, physiological, and ecological studies. Journal of Experimental Marine Biology and Ecology, vol. 297, p. 43-56, 2003.

COUSIN, M.; CUZON, G.; GUILLAUME, J.; AQUACOP. Digestibility of starch in Penaeus vannamei: in vivo and in vitro study on eight samples of various origin. Aquaculture, vol. 140, p. 361-372, 1996.

COUTTEAU, P. Filling the nutritional gaps in shrimp feed formulation. International Aqua Feed, nov.-dez, 2004.

CRUZ-SUÁREZ, L.E.; RICQUE-MARIE, M.; NIETO-LÓPEZ, M.; TAPÍA-SALAZAR, M. Revisión sobre calidad de harinas y aceites de pescado para la nutrición Del camarón. In: CIVERA-CERECEDO, R.; PÉREZ-ESTRADA, C.J; RICQUE-MARIE, D.; CRUZ-SUÁREZ, L.E. (Eds.) Avances em Nutrición Acuícola IV. Memorias del IV Simposium Internacional de Nutrición Acuícola 1998. México, 2000.

CUZON, G.; GUILLAUME, J. CAHU, C. Composition, preparation and utilization of feeds for Crustacea. Aquaculture, vol. 124, p. 253-267, 1994. 
.; HEW, M.; COGNIE, D.; SOLETCHNIK, P. Time lag of feeding on growth of juvenile shrimp, Penaeus japonicus bate. Aquaculture, vol. 29, p. 33-44, 1982.

D'ABRAMO, L.R.; CASTELL, J.D. Research Methodology. In: D'ABRAMO, L.R.; CONCLIN, D. E.; AKIYAMA, D.M. Crustacean Nutrition. Advances in World Aquaculture, vol. 6. USA: The World Aquaculture Society, 1997.

.; DANIELS, W.H.; GERARD, P.D.; JUN, W.H.; SUMMERLIN, C.G. Influence of water volume, surface area, and water replacement rate on weight gain of juvenile freshwater prawns, Macrobrachium rosenbergii. Aquaculture, vol. 182, p. 161-171, 2000.

.; REED, L.; HEINEN, J. M. A culture system for nutritional studies of crustaceans. Aquaculture, vol. 72, p. 379-389, 1988.

DALL, W. Feeding, digestion and assimilation in Penaidae. In: ALLAN, G.L.; DALL, W. (Eds.). Proceedings of the Aquaculture Nutrition Workshop 1991. Austrália, 1992.

.; HILL, B. J.; ROTHLISBERG, P. C.; SHARPLES, D. J. The Biology of the Penaeidae. Advances in Marine Biology, vol. 27. 1990.

DANIELS, W.H.; D'ABRAMO, L.R.; DE PARSEVAL, L. Design and management of a closed, recirculating "clearwater" hatchery system for freshwater prawns, Macrobrachium rosenbergii de Man, 1879. Journal of Shellfish Research, vol. 11 (1), p. 65-73, 1992.

DAVIS, D.A.; ARNOLD, C.R. The design, management and production of a recirculating raceway system for the production of marine shrimp. Aquacultural Engineering, vol. 17, p. 193-211, 1998.

DIMES, L.E.; HAARD, N.; DONG, F.M.; RASCO, B.A.; FORSTER, I.P.; FAIRGRIEVE, W.T.; ARNDT, R.; HARDY, R.W.; BARROWS, F.T.; HIGGS, D.A. Estimation of protein digestibility - II. In vitro assay of protein in salmonid feeds. Comp. Biochem. Physiol., vol. 108A, p. 349-362, 1994.

DIVAKARAN, S. Chromic oxide: The inert marker for in vivo digestibility studies in shrimp, problems and solutions. Aqua Feeds: Formulation \& Beyond, vol. 2, n. 1, 2005. 
.; VELASCO, M.; BEYER, E.; FORSTER, I.; TACON, A.G.J. Soybean meal apparent digestibility for Litopenaeus vannamei, including a critique of methodology. In: CRUZ-SUÁREZ, L.E.; RICQUE-MARIE, F.; TAPIA-SALAZAR, M. OLVERA-NOVOA, M.A.; CIVERA-CERECEDO, R. (Eds.) Avances en Nutrición Acuícola V, Memorias del $\mathbf{V}$ Simposium Internacional de Nutrición Acuícola. México, 2000.

EAPA (European Animal Protein Association). Sustainable resources secure the future of aquaculture: The use of natural animal proteins in fish feed to develop a more environmentally responsible and ecologically sustainable aquaculture. International Aquafeed, vol. 9, n. 4, p. 20-23, 2006.

EMBRAPA (Empresa Brasileira de Pesquisa Agropecuária). Embrapa Soja. 2008. Disponível em: <http://www.cnpso.embrapa.br/index.php?op_page=22\&cod_pai=16>. Acesso em: 06 fev. 2008.

EPA (Environmental Protection Agency's Office of Solid Waste). Test Methods for Evaluating Solid Waste. USA: EPA. 2004.

FAO (Food and Agriculture Organization of the United Nations). 2006. Fisheries Department. State of World Aquaculture 2006. FAO Fisheries Technical Paper, n. 500, Rome: FAO. 2007. Fisheries and Aquaculture Department. The State of World Fisheries and Aquaculture 2006. Rome: FAO.

FONSECA, C.; ROCHA, I.; LIMA, M.; ALENCAR, R.; CARVALHO, R.; MARQUES, T. Relatório Preliminar da Evolução da NIM nas Fazendas da Região NE. ABCC/MCR Aquacultura: Pernambuco, 2004. Disponível em: <http://www.lcm.ufsc.br/index.php?area=42\&cod=17>. Acesso em: 15 de jan. 2008.

FORSTER, I.P.; DOMINY, W..; OBALDO, L.; TACON, A.G.J. Rendered meat and meat bone meals as ingredients of diets for shrimp Litopenaeus vannamei (Boone, 1931). Aquaculture, vol. 219, p. 655-670, 2003.

GOLDBURG, R.; NAYLOR, R. Future seascapes, fishing, and fish farming. Front. Ecol. Environ., vol. 3 (1), p. 21-28, 2005. 
GÓMEZ-JIMENEZ, S.; URIAS-REYES, A.; VAZQUEZ-ORTIZ, F.; HERNANDEZWATANABE, G. Ammonia efflux rates and free amino acid levels in Litopenaeus vannamei postlarvae during sudden salinity changes. Aquaculture, vol. 233, p. 573-581, 2004.

GUZMÁN, F.D. Principales ingredientes a utilizar en dietas para acuacultura. In: JARAMILLO, M.P.S.; GÓMEZ, H.R.; CAZA, P.V. (Eds.) Fundamentos de nutrición y alimentación en acuicultura. Serie Fundamentos $N^{\circ} 3$. Colômbia: Instituto Nacional de Pesca Y Acuicultura, 1996.

HANSEN, H.P.; KOROLEFF, F. Determination of nutrients. In: GRASSHOFF, K.; KREMLING, K.; EHRHARDT, M. (Eds.). Methods of Seawater Analysis. Alemanha: Wiley-VCH, 1999.

HERTRAMPF, J. W.; PIEDAD-PASCUAL, F. Handbook on Ingredients for Aquaculture Feeds. Holanda: Kluwer, 2000.

HUGUENIN, J.E.; COLT, J. Design and Operating Guide for Aquaculture Seawater Systems. Developments in Aquaculture and Fisheries Science, 23. Holanda: Elsevier, 1989.

JORY, D.E.; CABRERA, T.R.; DUGGER1, D.M.; FEGAN, D.; LEE, P.G.; LAWRENCE, A.L.; JACKSON, C.J.; MCINTOSH, R.P.; CASTAÑEDA, J. A global review of shrimp feed management: status and perspectives. In: BROWDY, C. L.; JORY, D. E. (Eds.). The New Wave. Proceedings of the special Session on Sustainable Shrimp Culture, Aquaculture 2001. USA: World Aquaculture Society, 2001.

KAMIMURA, M.T. Desenvolvimento de um sistema de recirculação de água marinha para estudo com peixes e crustáceos. 2002. Monografia (Graduação em Oceanologia) - Departamento de Oceanografia, Fundação Universidade Federal do Rio Grande, Rio Grande.

KARZINKIN, G.S.; TARKOVSKAYA, O.I. Determination of caloric value of small samples. In: Pavlovskii, E.N. (Ed.) Techniques for the investigation of fish physiology. Israel Program. Sci. Transl. London: Oldbourne Press, p. 122-124, 1964. 
KRUMmenAUER, D.; WASIELESKY, W.; CAVALLI, R. O.; PEIXOTO, S.; ZOGBI, P. R. Viabilidade do cultivo do camarão-rosa Farfantepenaeus paulensis (Crustácea, Decapoda) em gaiolas sob diferentes densidades durante o outono no sul do Brasil. Ciência Rural, v.36, n.1, jan-fev, 2006.

KURESHY, N.; DAVIS, D.A. Protein requirement for maintenance and maximum weight gain for Pacific white shrimp, Litopenaeus vannamei. Aquaculture, vol. 204, p. 125-143, 2002.

LAWRENCE, A.L.; LEE, P.G. Research in the Americas. In: D'ABRAMO, L.R.; CONCLIN, D. E.; AKIYAMA, D.M. Crustacean Nutrition. Advances in World Aquaculture, vol. 6. USA: The World Aquaculture Society, 1997.

.; CASTILLE, F.; SAMOCHA, T., VELASCO, M. "Environmentally friendly" or "least polluting" feed and feed management for aquaculture. In: BROWDY, C.L.; JORY, D.E. (Eds.). The New Wave. Proceedings of the special Session on Sustainable Shrimp Culture, Aquaculture 2001. USA: World Aquaculture Society, 2001.

LEAVITT, D. F. An evaluation of gravimetric and inert marker techniques to measure digestibility in the American lobster. Aquaculture, p. 131-142, 1985.

LEE, P.G.; LAWRENCE, A.L. Digestibility. In: D'ABRAMO, L.R.; CONCLIN, D. E.; AKIYAMA, D.M. Crustacean Nutrition. Advances in World Aquaculture, vol. 6. USA: The World Aquaculture Society, 1997.

LEMOS, D. Testing quality of feeds and feed ingredients: in vitro determination of protein digestibility with enzymes from the target species. International Aquafeed, nov.-dez., 2003.

., D. Measuring protein quality in vitro: Using hepatopancreas extracts from shrimp, protein digestibility of feeds and ingredients can be reliable measured bench top. Aquafeeds: Formulation \& Beyond, vol. 3, n, 4, p. 11-14, 2006.

.; EZQUERRA, J.M.; GARCIA-CARREÑO, F.L. Protein digestion in penaeid shrimp: digestive proteinases, proteinase inhibitors and feed digestibility. Aquaculture, vol. 186, p. 89-105, 2000. 
; NAVARRETE DEL TORO, A.; CÓRDOVA-MURUETA, J.H.; GARCIACARREÑO, F. Testing feeds and feed ingredients for juvenile pink shrimp Farfantepenaeus paulensis: in vitro determination of protein digestibility and proteinase inhibition. Aquaculture, vol. 239, p. 307-321, 2004.

.; NETTO, B.; GERMANO, A. Energy budget for juveniles of the subtropical shrimp Farfantepenaeus paulensis. In: Realizing The Potential: Responsible Aquaculture for A Secure Future. Book of Abstracts: World Aquaculture 2003. Bahia: World Aquaculture Society, 2003.

.; NUNES, A.J.P. Protein Digestive Capacity: Correlated With Nutrient Presence, Availability In Shrimp Feeds. Global Aquaculture Advocate, nov.-dec., 2007a.

.; NUNES, A.J.P. Prediction of culture performance of juvenile Litopenaeus vannamei by in vitro ( $\mathrm{pH}$-stat) degree of feed protein hydrolysis with species-specific enzymes. Aquaculture Nutrition, vol. 13, p. 1-11, 2007b.

. ; PHAN, V.N. Ontogenetic variation in metabolism, biochemical composition and energy content during the early life stages of Farfantepenaeus paulensis (Crustacea: Decapoda: Penaeidae). Marine Biology, vol. 138, p. 985-997, 2001.

LIM, C.; DOMINY, W. Evaluation of soybean meal as a replacement for marine animals protein in diets for shrimp. Aquaculture, vol. 87, p. 53-63. 1991.

LIN, Y.-C.; CHEN, J.-C. Acute toxicity of ammonia on Litopenaeus vannamei Boone juveniles at different salinity levels. Journal of Experimental Marine Biology and Ecology, vol. 259, p. 109-119, 2001.

LONGAS, M.P.D. Formulación de dietas. In: JARAMILLO, M.P.S.; GÓMEZ, H. R.; CAZA, P.V. (Eds.). Fundamentos de nutrición y alimentación en acuicultura. Serie Fundamentos Nº 3. Colômbia: Instituto Nacional de Pesca Y Acuicultura, 1996.

MANDARINO, J.M.G.; RUFINO, C.F.G. Soja, Saúde e Alimentação: perguntas e respostas mais freqüentes. Série Documentos, 201. Brasil: Embrapa Soja, 2002 
MENDES, W.S.; SILVA, I.J.; FONTES, D.O.; RODRIGUEZ, N.M.; MARINHO, P.C.; SILVA, F.O.; AROUCA, C.L.C.; SILVA, F.C.O. Composição química e valor nutritivo da soja crua e submetida à diferentes processamentos térmicos para suínos em crescimento. Arq. Bras. Med. Vet. Zootec., vol. 56, n. 2, p. 207-213, 2004.

MUHLIA-ALMAZÁN, A.; GARCIA-CARREÑO, F. L. Influence of molting and starvation on the synthesis of proteolytic enzymes in the midgut gland of the white shrimp Penaeus vannamei. Comparative Biochemistry and Physiology Part B, vol. 133, p. 383-394, 2002.

MUIR, J. Managing to harvest? Perspectives on the potential of aquaculture. Phil. Trans. R. Soc. B, vol. 360, p. 191-218, 2005.

MUKHI, S.K.; DAS, B.K.; MADHAVI, B.; MISRA, C.K.; PRASAD, K.P. Shrimp farm waste and its management. Infofish International, vol. 1, p. 50-55, 2001.

NAYLOR, R.L.; GOLDBURG, R.J.; PRIMAVERA, J.H.; KAUTSKY, N.; BEVERIDGE, M.C.M.; CLAY, J.; FOLKE, J.; LUBCHENCO, J.; MOONEY, H.; TROELL, M. Effect of aquaculture on world fish supplies. Nature, vol.405, p. 1017-1024, 2000.

NUNES, A.J.P. Manual Purina de Alimentação para Camarões. São Paulo: Agribrands do Brasil, 2000.

.; GESTEIRA, T.C.V.; GODDARD, S. Food ingestion and assimilation by the Southern Brown shrimp Penaeus subtilis under semi-intensive culture in NE Brazil. Aquaculture, vol. 149, p. 121-136, 1997.

; SURESH, A.V. Marine shrimp farming in northeastern Brazil. World Aquaculture, vol. 32 (1), p. 32-38, 2001.

OBALDO, L. G.; DIVAKARAN, S.; TACON, A. G. Method for determining the physical stability of shrimp feeds in water. Aquaculture Research, vol. 33, p. 369-377, 2002.

OLIVEIRA, G. F. Composição dos ácidos graxos da fração lipídica de resíduos industriais da pesca. 2002. Monografia (Graduação em Oceanografia) - Centro de Ciências Tecnológicas da Terra e do Mar, Universidade do Vale do Itajaí, Itajaí. 
OSTRENSKY, A.; WASIELESKY, W. Acute toxicity of ammonia to various life stages of the São Paulo shrimp, Penaeus paulensis Pérez-Farfante, 1967. Aquaculture, vol. 132, p. 339-347, 1995.

PARIPATANANONT, T.; BOONYARATPALIN, M.; PENGSENG, P.; CHOTIPUNTU, P. Substituition of soy protein concentrate for fihmeal in diets of tiger Penaeus monodon. Aquaculture Research, vol. 32 (Suppl. 1), p. 369-374. 2001.

ROCHA, I.P.; CARVALHO, R.A.P.L.F. Advances in shrimp farming \& best management pratices in Brazil. International Aquafeed, vol. 9, n. 4, p. 16-19, 2006.

ROCHA, I.P.; RODRIGUES, J.A. Carcinicultura Brasileira em 2003. Revista da ABCC, 2004. Disponível em: <http://www.abccam.com.br/>. Acesso em: 12 abr. 2005.

ROSAS, C.; CUZON, G.; GAXIOLA, G.; LE PRIOL, Y.; PASCUAL, C.; ROSSIGNYOL, J.; CONTRERAS, F.; SANCHEZ, A.; VAN WORMHOUDT, A. Metabolism and growth of juveniles of Litopenaeus vannamei: effect of salinity and dietary carbohydrate levels. Journal of Experimental Marine Biology and Ecology, vol. 259, p. 1-22, 2001.

SHIAU, S.Y. Nutrient requirements of penaeid shrimps. Aquaculture, vol. 164, p. 77-93, 1998.

SHIPTON, T.A.; BRITZ, P.J. An assessment of the use of chromic oxide as a marker in protein digestibility studies with Haliotis midae L. Aquaculture, vol. 203, p. 69-83, 2001.

SMITH, D.M.; BURFORD, M.A.; TABRETT, S.J.; IRVIN, S.J.; WARD, L. The effect of feeding frequency on water quality and growth of the black tiger shrimp (Penaeus monodon). Aquaculture, vol. 207, p. 125-136, 2002.

.; TABRETT, S.J. Accurate measurement of in vivo digestibility of shrimp feeds.

Aquaculture, vol.232, p. 1-4. 2004.

SMITH, L.L.; LEE, P.G.; LAWRENCE, A.L.; STRAW, K. Growth and digestibility by three sizes of Penaeus vannamei Boone: Effects of dietary protein level and protein source. Aquaculture, vol. 46, p. 85-96, 1985. 
SMITT, A.S.C.; SANTOS, E.A. Ammonia-N efflux rate and nutritional state of juvenile pink shrimp, Penaeus paulensis (PerezFarfante), in relation to food type. Aquaculture Research, vol. 29, p. 495-502, 1998.

STICKNEY, R. R. Principles of Warmwater Aquaculture. EUA: John Wiley \& Sons, 1979.

SOARES, R.B. Comportamento alimentar de pós-larvas e juvenis do camarão-rosa Farfantepenaeus paulensis (Pérez-Farfante, 1967) em sistemas de cultivo. 2004. Tese (Doutorado em Oceanografia Biológica) - Fundação Universidade Federal do Rio Grande, Rio Grande.

SPOTTE, S. Seawater Aquariums: The Captive Environment. USA: Jonh Wiley \& Sons, 1979.

SUGIURA, S.H. Digestibility. In: STICKNEY, R.R. (Ed.) Encyclopedia of aquaculture. USA: Jonh Wiley \& Sons, 2000.

SWICK, R. A. Soybean meal quality: Assesing the characteristics of a major aquatic feed ingredient. The advocate, Apr. 2002

Soybean meal and soy protein concentrate for shrimp production. International Aquafeed, Mar-Apr. 2007.

TACON, A.G.J. Global Review of Feeds and Feed Management Practices in Shrimp Aquaculture. Report prepared under the World Bank, NACA, WWF and FAO Consortium Program on Shrimp Farming and the Environment. Work in Progress for Public Discussion. Consortium, 2002.

. New FAO Report: Use of fishery resourcea as feed inputs for aquaculture development - trends and policy implications. . International Aquafeed, vol. 9, n. 4, p. 34$35,2006$.

.; AKIYAMA, D.M. Feed Ingredientes. In: D'ABRAMO, L.R.; CONCLIN, D.E.; AKIYAMA, D.M. Crustacean Nutrition. Advances in World Aquaculture, vol. 6. USA: The World Aquaculture Society, 1997. 
; RODRIGUES, A.M.P. Comparison of chromic oxide, crude fiber, polyethylene and acid-insoluble ash as dietary markers for the estimation of apparent digestibility coefficients in rainbow trout. Aquaculture, vol. 43, p. 391-399, 1984.

WASIELESKY, W. Cultivo de juvenis do camarão-rosa Farfantepenaeus paulensis (Decapoda, Penaeidae) no estuário da Lagoa dos Patos: Efeitos de parâmetros ambientais e manejo de cultivo. 2000. Tese (Doutorado em Oceanografia Biológica) Fundação Universidade Federal do Rio Grande, Rio Grande.

WATANABE, T. Strategies for further development of aquatic feeds. Fisheries Science, vol. 68, p. 245-252, 2002.

WYBAN, J.; WALSH, W.A.; GODIN, D.M. Temperature effects on growth, feeding rate and feed conversion of the Pacific white shrimp (Penaeus vannamei). Aquaculture, vol. 138, p. 267-279, 1995.

WYK, P.V. Nutrition and Feeding of Litopenaeus vannamei. In: WYK, P. V.; DAVISHODGKINS, M.; LARAMORE, R.; MAIN, K. L.; MOUNTAIN, J.; SCARPA, J. Farming Marine Shrimp in Recirculating Freshwater Systems. USA: Harbor Branch Oceanographic Instituition 1999. Disponível em: < http://www.hboi.edu/aqua/training_pubs.html>. Acesso em: 15 jan. 2008. .; SCARPA, J. Water Quality: Requeriments and Management. In: WYK, P. V.; DAVIS-HODGKINS, M.; LARAMORE, R.; MAIN, K. L.; MOUNTAIN, J.; SCARPA, J. Farming Marine Shrimp in Recirculating Freshwater Systems. USA: Harbor Branch Oceanographic Instituition 1999. Disponível em: < http://www.hboi.edu/aqua/training_pubs.html>. Acesso em: 15 jan. 2008.

ZAR J. H. Biostatistical analysis. USA: Prentice Hall, 1984. 